\title{
The Immigrant-Native Wage Gap in Germany Revisited
}

\author{
Kai Ingwersen ${ }^{\dagger}$ \\ University of Hannover \\ Stephan L. Thomsen ${ }^{\ddagger}$ \\ University of Hannover, ZEW Mannheim, IZA Bonn
}

This version: 17 May 2019

\begin{abstract}
This study provides new evidence on the levels of economic integration experienced by foreigners and naturalised immigrants relative to native Germans from 1994 to 2015. We decompose the wage gap using the method for unconditional quantile regression models by employing a regression of the (recentered) influence function (RIF) of the gross hourly wage on a rich set of explanatory variables. This approach enables us to estimate contributions made across the whole wage distribution. To allow for a detailed characterization of labour market conditions, we consider a comprehensive set of socio-economic and labour-related aspects capturing influences of, e.g., human capital quality, cultural background, and the personalities of immigrants. The decomposition results clearly indicate a significant growing gap with higher wages for both foreigners (13.6 to $17.6 \%$ ) and naturalised immigrants (10.0 to $16.4 \%$ ). The findings further display a low explanation for the wage gap in low wage deciles that is even more pronounced within immigrant subgroups. Cultural and economic distances each have a significant influence on wages. A different appreciation of foreign educational qualifications, however, widens the wage gap substantially by 4.5 ppts on average. Moreover, we observe an indication of deterioration of immigrants' human capital endowments over time relative to those of native Germans.
\end{abstract}

Keywords: Immigration, wage gap, unconditional quantile regression, Germany

JEL Classification: J61, J31, J15

\footnotetext{
† Kai Ingwersen, Institute of Economic Policy, Königsworther Platz 1, D-30167 Hannover, * ingwersen@wipol.uni-hannover.de. ‡ Stephan L. Thomsen, Inst. of Economic Policy, Königsworther Platz 1, D-30167 Hannover, * thomsen@wipol.uni-hannover.de.
} 


\section{INTRODUCTION}

The continual globalization of societies fosters cultural diversity within national borders. In 2016, roughly 23.5 percent (19.5 million) of the German population had a so-called migration background, i.e., a personal migration experience or recent migration ancestry. ${ }^{1}$ With the recent inflow of migrants into Europe since 2014 (Eurostat, 2018b), opposing currents within the societies of European countries have become more visible. Germany as an immigration country cannot deprive from these contrary currents. As in many other countries of Europe and around the world, right-wing populist parties have recently achieved high rates of approval in elections. Sola (2018) finds a positive correlation between concerns about immigration and support for right-wing populist party “Alternative für Deutschland” (AfD) especially in eastern Germany. Critics of immigration in Germany are supported by the fact that the benefit system is demonstrably claimed by a growing number of foreigners (Riphahn et al., 2013). This public concern is fuelled by a perception of rising levels of income inequality (Roth et al., 2017). Although the development of inequality in terms of wages has stagnated in recent years (Biewen et al., 2017), ${ }^{2}$ research shows that especially low-skilled workers and immigrants are increasingly being negatively affected by wage inequality in Germany (e.g., Algan et al., 2010; Gernandt \& Pfeiffer, 2007). Because the wage gap between immigrants and natives is a good indicator of economic integration and reflects the effectiveness of a country's immigration and labour market policies, we study wage development trends for these groups in Germany in identifying a set of causes.

Using the immigrant-native wage gap to analyse uneven remuneration is sensible because wages generally serve as an indicator of individuals' levels of labour productivity. According to human capital theory, one's productivity is determined by one's abilities and skills, which are often expressed by one's level of education (e.g., formal qualification) and work experience (Aldashev et al., 2012; Tverdostup \& Paas, 2017) and therefore translated into earnings. Thus, a wage gap initially reflects a difference in productivity among workers and is not evident with discrimination against an individual or a particular group in the labour market (O’Neill \& O’Neill, 2015).

Regarding importance of inclusion, the labour market integration of immigrants is a major policy concern, as immigrants' contributions to the economy depend directly on their success. Together with social and cultural aspects, income and wages are indispensable to holistic assimilation (e.g., Lehmer \& Ludsteck, 2015, p. 677). In the first place, a welfare loss occurs due to insufficient job allocation. Immigrant employees may work in occupations below their qualifications and thus cannot exhaust their full production potential. In extreme cases, high wage differentials lead to larger unemployment assistance and social assistance payments in the medium run while social insurance contributions and tax revenues decrease. To identify triggers for counteracting social division, it is important to analyse whether wage differentials are due to observable differences in, for example, human capital endowments or due to unobservable influences

\footnotetext{
${ }^{1}$ A person with a migration background is defined as someone who immigrated to Germany or who has at least one foreign, immigrant or naturalised parent (Federal Bureau of Statistics, 2017a).

${ }^{2}$ Earnings discrepancies in Germany have reached average levels in Europe (Simón, 2010). The development of wage inequality from the 1990s to the early 2000s in Germany is addressed by Card, 2013; Dustmann et al., 2009; Gernandt \& Pfeiffer, 2007.
} 
comprising ethnic discrimination (Aldashev et al., 2012). ${ }^{3}$ A wage differential usually originates from limited access to the labour market (Aldashev et al., 2009; Brynin \& Güveli, 2012). To improve the employment and labour market prospects of foreigners, the German government become increasingly dedicated to offering courses specially designed for immigrants on language instruction, social integration, integration through apprenticeship, work, and (university) education (Federal Government, 2016; Kosyakova \& Sirries, 2017). Both the total number of courses and the demand for specific courses such as those on literacy and youth integration have increased over the last decade (BAMF, 2017).

We decompose the immigrant-native wage gaps for males for the years 1994 to 2015 using data from the German Socio-Economic Panel (SOEP) as a source of information. SOEP data include a rich set of household and labour-related characteristics relevant to understanding the determinants of labour market success across groups. We consider a rich set of control variables that recognizes typically unobservable labour market influences. In particular, we examine individual personality traits and integration barriers by taking into account metrics of immigrants' proximity to Germany based on their home countries' levels of cultural distance (Kanas et al., 2012). We also consider foreign education degrees and employ the home country's economic performance as an indicator of human capital quality (Coulombe et al., 2014). We estimate the immigrant-native wage gap by applying a variant of Blinder-Oaxaca decomposition to emphasize differences in returns. To consider heterogeneous effects observed along the whole wage distribution, we apply an approach proposed by Firpo et al. (2009) based on a recentered influence function (RIF) for unconditional quantile regression (UQR) models. This approach is mainly advantageous in its more precise decomposition, which allows one to estimate the contributions of each variable to composition effects observed along the entire wage distribution (Galego \& Pereira, 2014).

The variety of origins (and migration motives) involved makes it extremely difficult to depict the foreign qualifications of persons due to the presence of different education systems and requirements. Our study design is constructed to take this diversity explicitly into consideration. We differentiate between three main population groups in our analysis: Native Germans, Naturalised Immigrants, and Foreigners. We further consider (i) citizens of Turkey, (ii) citizens of the former Yugoslavia, and (iii) citizens of southern European countries as subgroups of Foreigners, as the influx of guest-workers during the 1960s and subsequent family reunification that occurred in the following decades formed large demographic groups from the Mediterranean within Germany. Naturalised Immigrants are further divided into (j) ethnic German repatriates and (jj) naturalised immigrants without ethnic immigrants. For further information on German migration history, see Appendix C.

Our empirical results show a significant gap in wages for Foreigners and Naturalised Immigrants relative to Native Germans without a migration background for the more than two decades of analysis. Regarding individual and labour market characteristics affecting wages, on average, roughly three quarters of gaps along the wage distribution can be attributed to observable differences in individuals' human capital endowments and work-related factors but with distinct differences observed between immigrant groups. With respect to human capital transferability across borders, a perceptible disadvantage can still be

\footnotetext{
${ }^{3}$ A pay disadvantage or even discrimination against an equivalent job occurs when the same degree of employee labour productivity - equal qualifications and (labour market) experience, similar personal characteristics and equal overall conditions (sector, etc.) - is remunerated to varying degrees. For further details on direct and indirect discrimination see OECD (2013).
} 
attributed to education obtained abroad. This implies an insufficient adaptation of qualifications in Germany. Furthermore, we observe a rising gap in average wages for both immigrant main groups over time. We find a consistently high degree of explanation due to individual and labour market characteristics indicating that the human capital endowments of immigrants have deteriorated relative to those of native Germans over time. Given the above mentioned strong public and private efforts made to socially and economically integrate immigrants in Germany, these results raise doubts surrounding the effectiveness and efficiency of such programmes.

The remainder of this paper is organized as follows: We first review the related literature on wage inequality and the wage gap. Section 3 provides information on the data used for the empirical analysis, which is followed with a presentation of selected descriptive statistics (section 4). We introduce the econometric approach of the decomposition method in section 5. The empirical results are illustrated and evaluated in section 6 . The final section provides conclusions.

\section{RELATED LITERATURE}

Wage differentials between natives and foreigners have been analysed in a number of studies. Because the convergence of immigrants' wage levels to natives' wage levels serves as an important indication of their degrees of labour market integration, a recurring contemplation of wage differences between these groups is essential to uncovering structural and persistent disadvantages (Coulombe et al., 2014). Despite current political and societal discussions, however, much of the evidence available for Germany refers to the period surrounding the turn of the millennium. A more recent account on the situation of the last decade is not available. The results from earlier studies note levels of wage discrimination against immigrants of 13 to 17 percent in western Germany for 1996 to 2005 (Bartolucci, 2014). ${ }^{4}$ At the same time, Lehmer \& Ludsteck (2011) identify a heterogeneous pattern of immigrant salary disadvantages depending on the country of origin (1995-2006). ${ }^{5}$ Here, even lower wages can be observed for second-generation immigrants (Algan et al., 2010). ${ }^{6}$ Further results provided by Aldashev et al. (2012) reveal significant wage gaps for both foreigners (25 \%) and naturalised immigrants (19 \%) based on SOEP data for 1992 to 2009.

However, Germany is not the only country in Europe experiencing wage inequality between its host and immigrant population. The majority of migrants within the European Union face income disadvantages, which tend to be even more pronounced for migrants from non-EU countries than for migrants from EU member states (Adsera \& Chiswick, 2007; Lehmer \& Ludsteck, 2011, 2015). For Austria, where the share of foreigners is higher than that in Germany, Hofer et al. (2017) reveal a wage gap between immigrants and natives of 15 percent for 2008 to 2010; the majority of this wage gap can be attributed to differences in human capital endowments. Moreover, wage differentials tended to be larger for higher incomes in 2008. For Germany, related evidence indicates the opposite trend: the wage gap decreases steadily with higher incomes and may turn even positive at a wage peak (Grandner \& Gstach, 2015, p. 63).

Generally, wage differences between natives and immigrants can be attributed to a lack of host country-specific human capital. Therefore, immigrants face an initial income disadvantage upon arrival

\footnotetext{
${ }^{4}$ Bartolucci (2014) uses matched employer-employee data (LIAB) from the Institute for Employment Research (IAB).

${ }^{5}$ Lehmer \& Ludsteck (2011) use employment register data (BEH) of the German Federal Employment Agency.

${ }^{6}$ Algan et al. (2010) use data from German Mircocensus 2005/2006.
} 
relative to natives (Fertig \& Schurer, 2007; Tverdostup \& Paas, 2017). To compensate for this lack of required human capital, immigrants immediately start on a path with high(er) investment costs. Hence, earnings are low directly after arrival, but high levels of human capital will guarantee assimilation into the host labour market afterwards (Borjas, 1985), leading to the diminution of the initial income gap (Fertig \& Schurer, 2007). By acquiring knowledge on the language, customs, and nature of the labour market of the host country over time, immigrants can achieve supplementary and holistic assimilation. These factors can have positive effects in terms of raising immigrants' earnings. In addition, it should be noted that a positive self-selection of immigrants concerning assimilation is likely. A long period of residence in the host country may be accompanied with successful integration into the labour market and into society whereas unsuccessful integration may increase the probability of remigration (Gundel \& Peters, 2008). Related to this, Gathmann \& Keller (2018) show that faster access to German citizenship promotes immigrants' incentives to invest in skills, thereby causing them to enhance their labour market performance (earnings) and establish social contacts with the domestic culture. All of these processes result in deeper levels of social and cultural integration (Felfe et al., 2019). Therefore, not all immigrants will invest in host countryspecific human capital or seek jobs of higher status when investment costs exceed expected returns, i.e., when these are relatively high and the time of stay is presumably temporal (Kogan, 2011). As a result, assimilation effects may be overestimated when self-selection is not adequately regarded.

Nevertheless, due to its correlation with social and cultural assimilation, the time of residence may be an important factor shaping naturalised immigrants' and foreigners' wages (Chiswick, 1978). Descriptive statistics given by Lehmer \& Ludsteck (2015) show a decline in wage differences between immigrants and natives in Germany. According to their results, immigrants assimilate through the accumulation of firm-specific human capital and by moving to better paying firms, i.e., immigrants realize search gains. The process of assimilation slows down throughout the appropriation of host country-specific human capital (Borjas, 2015). This assimilation behaviour among immigrants is tested conventionally under the framework of the assimilation hypothesis developed by Chiswick (1978). Based on this concept, Fertig \& Schurer (2007) estimated a catch-up interval of wages of approximately nine years for Germany and the USA. Nevertheless, Borjas (1985:465) directly criticizes the assimilation hypothesis due to cohort effects.

A key component of host country-specific human capital is language proficiency (Gundel \& Peters, 2008). Hochman \& Davidov (2014, p. 352) confirm that proficiency in the host country's language is central to immigrants' labour market achievements. The effect of language on wages, however, is usually underestimated (Dustmann \& Van Soest, 2002) because insufficient levels of language proficiency diminish the probability of immigrant labour market participation and therefore may not affect wages fully (Aldashev et al., 2009). Language proficiency, however, is a prerequisite to holding professions of higher standing. The results by Guven \& Islam (2015) indicate that poor language skills particularly in childhood imply significant disadvantages in terms of social assimilation and academic and labour market success. According to Christl et al. (2018), closely related literacy skills also have a significant impact on wages and explain the wage differential between immigrants and natives to a certain extent.

Whether education is obtained from the host or home country serves a further strong explanation for the immigrant-native wage gap (Fortin et al., 2016; Warman et al., 2015). Regarding the educational levels of persons of foreign backgrounds, human capital obtained in the home country may not be equivalent to that 
obtained in the host country due to the limited transferability of skills and due to imperfect compatibility of home and host country labour markets (Basilio et al., 2017). Indeed, Basilio et al. (2017) consider lower levels of human capital quality and the incomplete transferability of human capital to be major factors in explaining the wage differential between natives and immigrants in Germany. The returns to education and labour market experience obtained outside of Germany are demonstrably lower than those to human capital obtained in Germany (Aldashev et al., 2009). The acquisition of host country-specific skills is exacerbated further by greater linguistic and cultural distance between countries of origin and the host country. The more similar two countries are in language and culture, the easier it is to acquire these resources (Isphording \& Otten, 2014). It is therefore necessary to quantify the influence of cultural differences on labour market success.

Cognitive abilities are complemented with personality traits as determinants of labour market success. While certain personality traits result in stronger job performance, others may be unfavourable in the labour market. For example, people with certain dispositions of personality traits may gain easier access to specific occupations and positions than others (Brenzel \& Laible, 2016; Heineck \& Anger, 2010; John \& Thomsen, 2014). Because cognitive abilities and personal characteristics influence each other, an early investment in character-shaping activities is required. The recent empirical labour literature therefore increasingly reflects the role and significance of cognitive abilities. Personality traits affect wages mostly through the channel of educational attainment and through a higher likelihood of engaging in labour market participation accompanied with more social integration (Thiel \& Thomsen, 2013). Unique characteristics already lead to greater success on the educational path (Busato et al., 1999).

These and other factors influencing wage inequality have to be evaluated at different levels. For instance, Giesecke \& Verwiebe (2009) show a decreasing wage differential between highly educated and less skilled employees in Germany but at the same time increasing wage differentials between occupational classes. Occupations also explain a large proportion of ethnic wage differentials in the United Kingdom (Longhi, 2017). At the same time, payment differentials within and between industries reinforce the existing wage gap between natives and immigrants, especially since immigrants are concentrated in sectors of manual activity (Antonczyk et al., 2010; Aydemir \& Skuterud, 2008). Furthermore, a change in employment patterns, e.g., the growth of (marginal) part-time work, contributes to an overall increase in wage inequality (Biewen \& Juhasz, 2012). Longhi (2017) concurrently highlights the spatial level of wage discrimination and stresses that estimated ethnic wage differentials are fundamentally overstated when they refer to the national level. When minorities are compared to the majority in the same local labour market while facing similar socio-economic conditions, the results reveal that ethnic wage differentials tend to be even more heavily underestimated.

\section{DESCRIPTION OF THE ESTIMATION SAMPLE}

For the empirical analysis, we use data from the German Socio-Economic Panel (SOEP). The SOEP is a wide-ranging and representative longitudinal panel study of roughly 11,000 private households where roughly 30,000 persons are interviewed annually on issues related to income, employment, education and health (see Goebel et al., 2018 for more information). We focus on the survey waves from 1994 to 2015 to exclude short-term fluctuations in the labour market occurring at the start of the 1990s. We consider strong 
waves of immigration occurring after the downfall of the Iron Curtain to secure sufficient sample sizes for each ethnic group and especially for ethnic German repatriates. ${ }^{7}$

Our variable of interest 'gross hourly wage' is obtained by dividing the gross wages for each month by the reported real working hours of the last week extrapolated to monthly hours. We assume that there are 4.35 weeks in each month for the calculation. To analyse developments occurring over 22 years, we adjust wages for inflation using the GDP deflator and measure them in prices for 2010. We further apply symmetric trimming to the wage distribution by dropping the upper and lower two percent from the analysis to correct for outliers.

The comprehensive set of socio-demographic variables included in the SOEP allows for the identification of immigration status beyond the concept of citizenship. In particular, information on whether a person or one parent immigrated to Germany (immigration background) can be collected by combining a persons' citizenship, country of origin and year of immigration to Germany (see Aldashev et al., 2012). In our empirical analysis, we distinguish between Foreigners, Naturalised Immigrants and Native Germans:

- Foreigners are all persons without German citizenship. We further consider three subgroups covering the main regions of origin of guest-workers from the 1960s: 'citizens of Turkey', 'citizens of the former Socialist Federal Republic of Yugoslavia (SFRY),8 and 'citizens of southern European countries' (Greece, Italy, Spain and Portugal).

- Naturalised Immigrants are former citizens of foreign countries who received German citizenship at or after immigration to Germany. Since Naturalised Immigrants are a highly heterogeneous group given the different origins and motivations for naturalisation, we distinguish between 'ethnic German repatriates' and 'naturalised immigrants without ethnic Germans' as two separate groups. We define 'ethnic German repatriates' as persons with German citizenship originating from countries of the former Soviet Union ${ }^{9}$ or from Eastern Europe ${ }^{10}$ and arriving in Germany after 1987. ${ }^{11}$

- The remaining persons form the group of Native Germans. However, we distinguish between native Germans with and without an indirect migration background. 'Native Germans with an indirect migration background' represent the second generation of naturalised immigrants. As a reference group, we use 'native Germans without a migration background' to avoid strong cultural and language ties to (partly) naturalised parents.

Distinguishing between these groups is useful to identify potential differences and similarities between ethnic groups. We look at naturalised immigrants separately, as they clearly differ in their labour market characteristics (see below) from those of foreigners and native Germans. Legally, naturalised immigrants are not distinguishable from native Germans (the same political participation rights), but foreign roots may determine a divergent cultural and economic background. Since these people possess skills predominantly

\footnotetext{
${ }^{7}$ Ethnic German repatriates are individuals with German ethnicity from successor states of the former Soviet Union and from other Eastern European states who returned to their ancestral homeland to settle permanently.

${ }^{8}$ The group also includes SFR Yugoslavia's successor states: Slovenia, Croatia, Bosnia and Herzegovina, Serbia (incl. Kosovo), Montenegro and Macedonia.

${ }^{9}$ Russia, Ukraine, Moldavia, Belarus, Kazakhstan, Tadzhikistan, Turkmenistan, Kirgizstan, Uzbekistan, Estonia, Latvia, Lithuania, Georgia, Armenia, and Azerbaijan.

${ }^{10}$ Poland, the Czech Republic and Slovakia (formerly Czechoslovakia), Hungary, and Romania but not Bulgaria (earlier repatriation).

11 The definition of 'ethnic Germans repatriates' is imprecise to a certain extent because all immigrants from the selected countries who have acquired German citizenship are considered and not just ethnic Germans alone. As SOEP data statistics show high immigration rates for each selected country of origin only for the beginning of the 1990s, a good approximation persists.
} 
obtained abroad, they may be valued differently in the highly regulated German labour market. In addition, naturalised immigrants can be expected to differ from foreigners in terms of their time of residence and intentions to stay in Germany. In calculating cultural distances, we use the revised measurement method developed by Kaasa et al. (2016), which is based on a revision of Hofstede's (1980) original work. Hofstede's approach assumes that the most important cultural differences can be captured by four cultural dimensions: power distance, uncertainty avoidance, individualism-collectivism, and masculinityfemininity (see Kaasa et al., 2016, p. 234). ${ }^{12}$

We further consider individuals' personality traits using the widely adopted Big Five personality traits. This approach defines personality comprehensively based on five independent domains. John \& Thomsen (2014, p. 554) characterize the Big Five traits as follows: (1) Conscientiousness relates to whether a person is reliable, organized, and responsible. (2) Extraversion corresponds to an enthusiastic, outgoing attitude, while (3) Agreeableness relates to a kind and compassionate attitude. (4) Neuroticism instead is defined as being unstable, prone to worry, and anxious and finally (5) Openness to Experience refers to imaginative, original individuals with broad interests. The values of the Big Five are averaged and standardized on the basis of three questions each.

To consider occupational selection, we refer to a classification developed by Erikson-GoldthorpePortocarero (EGP) that clusters occupations by social status. The lower end of the scope is reflects unskilled manual occupations for which no vocational training is required, and the upper end reflects higher services covering managers and academic occupations. We augment the available data by regional information at the state level to control for the regional economic environment and for labour force supplies in the empirical analysis using statistics provided by the Federal Employment Agency (2017) and the Federal Bureau of Statistics (2017b). The incorporated regional information includes, among other data, the share of the foreign population to depict the ethnic composition. A high ethnic concentration has a significantly negative effect on immigrants' levels of German language proficiency (Danzer \& Yaman, 2016) and leads in general to lower investments in human capital (Battisti et al., 2018). Table A. 1 of the appendix provides a detailed description of the variables considered.

For homogeneity reasons, we impose a number of restrictions on the estimation sample. We only consider first generation immigrants living in western Germany (incl. Berlin) - which means persons who were born abroad and who have immigrated to Germany. To ensure a reliable comparison of groups, we concentrate our analysis on the population of prime aged males (25 to 54 years) in full-time employment. The restriction of full-time employment is necessary because part-time jobs and atypical employment may vary between groups. For the same reason, self-employed persons, civil servants and soldiers are not regarded either. ${ }^{13}$ Focussing on males ensures avoiding biased interpretations due to differences in labour market-relevant characteristics between females and males and in labour force participation rates of females by origin (Ñopo, 2008). The age range is limited at both ends due to different patterns of participation in

\footnotetext{
12 (1) Power distance shows the extent to which less powerful individuals of a society accept and expect an unequal distribution of power. (2) Uncertainty avoidance reveals to what degree people feel comfortable with uncertainty. Laws, guidelines, and security measures characterize cultures with a high uncertainty avoidance. (3) Masculinity shows to what degree masculine values, such as orientation towards achievement, success, and assertiveness prevail over female values like caring, cooperation, and modesty. (4) Individualism describes the extent to which people appreciate to act as individuals rather than as members of a collectivist culture (Kaasa et al., 2016).

${ }^{13}$ The rate of self-employment is marginally larger for Germans (10.2\%) than for foreigners (10.0\%) (Federal Bureau of Statistics, 2017b).
} 
the educational system at the lower level and due to differences concerning (early) retirement at the upper end. With these restrictions in place, the estimation sample includes 52,165 observations of Native Germans without a migration background (76.9\%), 6,276 observations of Naturalised Immigrants (9.3\%), and 9,383 observations of Foreigners (13.8 \%) (see Table A. 2 of the appendix for a detailed description).

\section{DESCRIPTIVE STATISTICS}

Before turning to the econometric methodology and empirical estimates, we discuss wage development occurring within and across immigrant groups over time. Proceeding from an almost unchanged mean log hourly wage level for Native Germans without a migration background since 2004 (see Figure B. 1 of the appendix), we illustrate the wage development of immigrant groups through wage divergences (Figure 1).

$<$ Figure 1 about here $>$

Both Foreigners and Naturalised Immigrants present a considerable wage gap relative to Native Germans. The wage gap for Naturalised Immigrants consistently increased between 1994 and the beginning of the 2000s (-1 to $-6 \%$ ); afterwards, it declined slightly ( $-4.5 \%)$. On the other hand, the wage gap for Foreigners initially narrowed in phases (-5.5 to $-3.5 \%$ ) but since the 2000 s has widened substantially $(-7.5 \%)$

Wage development within the immigrant subgroups is more differentiated. Although citizens of Turkey and citizens of southern European countries show almost the same average wage level in 1994 (-6 \%), their wage gap development runs in opposite directions. While Southern Europeans almost caught up with Native Germans' wages in the 2000s (and declined afterwards), the wage gap for Turkish citizens has remained constantly low. Additionally, for citizens of Turkey, the wage gap has widened since 2011 relative to Native Germans (-10 \%). Compared to other foreigners, citizens of the former Yugoslavia had an even lower average wage level in 1994 (-8 \%). While their situation improved especially between 2005 and 2008 , a sharp decline to the same extent followed directly afterwards ( \pm 6 ppts). The wage gap for Ethnic German repatriates continually diminishes relative to Native Germans (-4.5\%) but also undergoes a minor wage drop in 2011. The wage development of naturalised immigrants without ethnic Germans is the most conspicuous because wage levels exceed Native Germans' average wages in the 1990s. Between 2000 and 2002, the group experienced a sharp drop in wages until it successively reached the level of other immigrant groups in 2010 (-5\%). We observe temporal coincidence with the introduction of the new citizenship law in 2000, which abruptly gave a large number of foreigners the right to German citizenship. This may have led to positive self-selection in naturalisation regarding the socio-economic status of foreigners. We confirm this result with a robustness check. A cautious regeneration of the wage gap started in 2011.

Previous literature and a descriptive comparison of wages already reveal an immigrant-native wage gap independent of the regarded immigrant group (see section 2). To understand the causes of such wage differences, it is necessary to examine the labour market-related characteristics of each group. A characterization of the estimation sample based on descriptive statistics is given in Table 1. To emphasize differences in means between the group of Native Germans without a migration background and each immigrant group, we present significant differences obtained by $t$-tests. The statistics show that 
corresponding waves of immigration can be easily identified with reference to the time of residence. Despite comparable ages, ${ }^{14}$ differences in labour market experience can be observed: Citizens of southern European countries and naturalised immigrants without ethnic Germans have significantly higher levels of mean labour market experience for 1994 to 2015 (each 19 years) than Native Germans (18 years). Citizens of the former Yugoslavia (17 years) and especially citizens of Turkey and ethnic Germans repatriates have significant less experience (16 years each).

\section{< Table 1 about here >}

Furthermore, we consider education as an indicator for qualification at three levels. Based on the CASMIN educational classification, people without formal occupational training are regarded as low-skilled, persons with occupational training are medium-skilled, and those with a college or university degree are considered highly skilled. The share of low-skilled persons is statistically higher across all immigrant groups but is the most pronounced for the group of Foreigners. Accordingly, all immigrant groups - except for naturalised immigrants without ethnic Germans - have lower shares of highly skilled workers. Moreover, naturalised immigrants without ethnic Germans exhibit the lowest shares of persons who have completed their highest education abroad (38 \%) while ethnic German repatriates - who immigrate at a comparatively higher age - present the highest ratio (68\%).

When considering the home country's economic performance in the year of immigration as a human capital quality indicator, we observe the largest economic distances to the countries of origin for ethnic German repatriates and Yugoslavs. On the other hand, the distance for southern European countries is relatively small. German language proficiency (speaking, reading and writing) is represented as a selfassessment of writing skills in the German language whereby skills are evaluated with scores of 1 (not at all) to 5 (very good). We note a slightly positive correlation with time of residence in Germany for all groups in consideration.

Furthermore, a larger cultural distance - expressed as, e.g., language, religion, and social norms between home and host countries could hamper social integration. The cultural distance to Germany is the largest for Turkey. Turkish culture is characterized by different epochs and ethnicities and is heavily influenced by Islam. The average cultural distance to southern European countries is considerably lower. The culture of Naturalised Immigrants is highly heterogeneous and therefore the average value offers limited information. A comparison of Big Five traits (see Table A. 3 of the appendix) reveals significant differences in average personality traits between ethnic Germans repatriates, citizens of southern European countries and occasionally citizens of Turkey relative to Native Germans. The two latter immigrant groups are very similar in their characteristics.

As is reported extensively in the literature, occupational segmentation serves as a strong explanation for wages. As foreigners were recruited in the 1960s and 1970s predominantly for work of low status, there was a corresponding high levels of ethnic stratification across occupations (Constant \& Massey, 2005). This pattern has remained very persistent over time. While immigrants still mainly perform jobs involving manual tasks (skilled and unskilled), Native Germans are relatively more highly specialized in high and

\footnotetext{
${ }^{14}$ The structure of the panel dataset leads to an uneven change in the age structure of immigrant groups relative to native Germans, as immigration is uneven in time and as age selection is given.
} 
low services. ${ }^{15}$ These differences are reflected in their distribution across economic sectors. The sectoral distribution may be explained by language proficiency whereby, e.g., in the service sector stronger language skills are generally required than in occupations mainly involving manual tasks. Furthermore, Foreigners work more often in small- and medium-sized firms than Native Germans. Overall, immigrant groups and Native Germans differ verifiably in their work-related characteristics.

\section{ECONOMETRIC METHODOLOGY}

\subsection{WAGE GAP DECOMPOSITION}

The descriptive statistics show significantly divergent log hourly wages between Native Germans and each of the immigrant groups. To quantify the underlying causes of wage differences, we apply Blinder-Oaxaca decomposition for unconditional quantile regression (UQR) models. The widely used Blinder-Oaxaca method decomposes mean wage differentials into explanatory determinants and an unexplained part. In its original settings, the decomposition technique uses a wage equation taking the form of a linear regression estimation $Y_{i}^{j}=X_{i}^{j} \beta^{j}+\varepsilon_{i}^{j}$ for individuals $i$ of group $j \in\{A, B\}$. The mean difference $R$ between groups A and $\mathrm{B}$ can be formulated as follows:

$$
R=\bar{Y}_{A}-\bar{Y}_{B}=\bar{X}_{A}^{\prime} \hat{\beta}_{A}-\bar{X}_{B}^{\prime} \hat{\beta}_{B}
$$

where $\bar{Y}$ denotes output means while $\bar{X}$ denotes sample averages of the explanatory variables for each group. Here, $Y_{i}^{j}$ is the vector $\log$ hourly wage of an individual within one group, $X_{i}^{j}$ is the data matrix containing independent variables, e.g., individual and labour market characteristics (including a constant), $\beta^{j}$ is the vector of regression coefficients, and $\varepsilon_{i}^{j}$ is the vector of random errors (Jann, 2008). The decomposition method divides the outcome difference of the wage equation into two components:

$$
R=\left(\bar{X}_{A}-\bar{X}_{B}\right)^{\prime} \hat{\beta}_{A}+\bar{X}_{B}^{\prime}\left(\hat{\beta}_{A}-\hat{\beta}_{B}\right) .
$$

The first term $\left(\bar{X}_{A}-\bar{X}_{B}\right)^{\prime} \hat{\beta}_{A}$ represents the "endowment effect" attributable to mean differences in background characteristics (e.g., education and experience). The second term $\bar{X}_{B}^{\prime}\left(\hat{\beta}_{A}-\hat{\beta}_{B}\right)$ denotes the "coefficient effect" and represents differences in returns to similar characteristics. ${ }^{16}$

Firpo et al. (2009) revaluated this approach and recommend the Blinder-Oaxaca decomposition for UQR models. Instead of using the simple mean, their method enables one to estimate the effect of a particular covariate on the wage structure and on composition effects along the entire wage distribution (Galego \& Pereira, 2014). "Unconditional quantiles” are quantiles of the marginal distribution of the outcome variable (Firpo et al., 2009, p. 953).

The approach is based on a regression of the recentered influence function (RIF), which is similar to a standard OLS regression except that dependent variable Y (in our case: the log wage) is replaced by the

\footnotetext{
${ }^{15}$ The intensity of skill use at work is relevant in explaining the immigrant-native wage gap. A Europe-wide study proves that immigrants, even when they acquire skills comparable to those of natives, use their skills less often at work (Tverdostup \& Paas, 2017). See Peri \& Sparber (2009) on the task-specialisation of foreign- and native-born workers.

${ }^{16}$ We use twofold decomposition because the additional "interaction effect" of threefold decomposition has no relevance to our study purpose.
} 
RIF of the statistic of interest (Fortin et al., 2011, p. 76). An influence function measures the influence of a single observation on a distributional statistic. The RIF of the $\tau^{\text {th }}$ quantile is given by the following expression (Galego \& Pereira, 2014, p. 2516):

$$
R I F\left(Y, q_{\tau}\right)=q_{\tau}+\frac{\tau-I\left(Y \leq q_{\tau}\right)}{f_{Y}\left(q_{\tau}\right)} .
$$

It is computed by estimating the marginal density $f_{Y}\left(q_{\tau}\right)$ of $Y$ for sample quantile $q_{\tau}$. This is achieved by using kernel methods and by forming a dummy variable $\mathrm{I}\left(\mathrm{Y} \leq \mathrm{q}_{\tau}\right)$ indicating whether the value of the outcome variable falls below $\mathrm{q}_{\tau}$ (Firpo et al., 2009, p. $954 \mathrm{ff}$ ). Afterwards, the dependent variable Y of the wage regression is replaced with the corresponding RIF (Fortin et al., 2011). ${ }^{17}$ In the last step, Blinder-Oaxaca decomposition is finally executed for each $q_{\tau}$ as the unconditional quantile regression model. ${ }^{18}$

\subsection{INTERPRETATION}

The coefficient effect of the decomposition exposes differences in returns and is commonly appraised as a measure of discrimination investigating wage discrepancies (Firpo et al., 2018; Jann, 2008). However, this interpretation is vulnerable because the unexplained component captures both the effects of discrimination and unobserved group differences (Lehmer \& Ludsteck, 2011; O’Neill \& O’Neill, 2015). Unobserved causes of wage gaps may underlie individuals’ soft motives (e.g., motivation, preferences, and aspirations), further unobservable skills (e.g., negotiating skills and assertiveness), or cultural and social norms in general. On the other hand, adding more control variables inevitably reduces the estimated magnitude of discrimination (Grandner \& Gstach, 2015). In conclusion, the unexplained part of the decomposition serves as only an indication of discrimination and less as proof (Canal-Domínguez \& Rodríguez-Gutiérrez, 2008).

In addition, Altonji \& Blank (1999) emphasize that it is also deceptive to label this second component alone as the result of discrimination, as discriminatory barriers in the labour market can affect the characteristics of individuals. Regardless of the chosen model, the direct comparison of individuals or groups is limited: certain combinations of individual characteristics and job requirements are only possible for one group and may not be for others (Ñopo, 2008).

\subsection{IMPLEMENTATION}

The final model specification used for the estimation of wage gap decomposition is the result of a deductive process of variable selection. In the wage equation, we consider as the base set of independent variables the individual characteristics of labour market experience (and its square), a cohabitation dummy, three skill levels obtained from the international education classification, and an indicator of German language proficiency. We further control for job-related attributes such as firm size (categorical), dummy variables for industry affiliation, and dummy variables for occupational class. In addition, time and regional fixed effects are included. We augment the model with regional information at federal state level by

\footnotetext{
17 Fortin provides a Stata package rifreg to perform RIF-regressions and package oaxaca8 for enhanced Blinder-Oaxaca decompositions (Fortin, n.d.).

${ }^{18}$ The even distribution of all observations among quantiles may lead to different ratios between immigrant groups and native Germans within the respective quantiles.
} 
approximating the economic environment and the labour force supply: the region's settlement structure type, the share of the foreign population, real GDP per capita, and the unemployment rate. Furthermore, we use survey weights at the individual level to mitigate a potential bias due to the over-representativeness of high-income households and immigrants in SOEP data.

The wage gap decomposition is computed for each decile of the wage distribution. We consider the first to ninth quantiles because for the method to work, observations made above our highest percentile of interest are required. Endowment and coefficient effects for each of the nine wage sections are estimated.

We implement various model specifications to test for the influence of foreign degrees, human capital quality, personality, and cultural distinctness. We assume that a large cultural and economic distance as well as the limited transnational transferability of human capital prove to be a disadvantage in the German labour market. Furthermore, we review the labour market situation of immigrants over time because we assume that a rising wage gap due to various legislative amendments. The reforms have predominantly caused part-time work in manual occupations where immigrants are highly concentrated. We present the results for the two immigrant main groups of Foreigners and Naturalised Immigrants and supplement them with results for the subgroups. The derivation of the model specification precedes the respective results.

\section{ESTIMATION RESULTS}

\subsection{THE IMMIGRANT-NATIVE WAGE GAP}

The wage gap decompositions show different results for Foreigners and Naturalised Immigrants. ${ }^{19}$ For the period 1994 to 2015, we find substantial wage gaps for both main groups relative to Native Germans. Naturalised Immigrants' wage gaps relative to Native Germans reach 10.0 to 16.4 percent, rising with higher wage deciles (mean: $13.1 \%$ ). ${ }^{20}$ At the same time, the endowment effect rises from 50 to 100 percent (mean: $81 \%$ ). Therefore, a large proportion of the wage gap for low wage deciles remains unexplained when capturing unobserved factors of influence. The wage gap for Foreigners is consistently higher and less diverse between the deciles than for Naturalised Immigrants (13.6-17.6 \%, mean: 14.8 \%). The explanatory power of individuals' endowments of Foreigners is greater overall than it is for Naturalised Immigrants and reaches shares of 75 to 85 percent for low and middle wage deciles (see Figure 2). ${ }^{21}$ However, the endowment effect reveals an overvaluation of high wage deciles, suggesting above-average remuneration in terms of qualification (mean: 100 \%). For both Naturalised Immigrants and Foreigners, the explanation of the wage gap is mainly driven by individuals' levels of language proficiency and by occupation in high and low services (see Figure B. 2). Education has only a slightly positive effect.

\footnotetext{
${ }^{19}$ The RIF-regression wage model estimates reveal comparable effects of the independent variables on wages for the principal groups (Table A. 4, Table A. 5 and Table A. 6 of the appendix). A person's labour market experience and higher educational level each have a significantly positive impact on wages for all groups. Here, the influence of higher education is enhanced with higher wages. Furthermore, larger firms pay significantly higher wages on average. For Native Germans and Foreigners, this impact of firm size is comparatively strong at lower wages. The industrial sectors of 'manufacturing' and 'construction' are both important factors explaining the low wages of Foreigners. While service-based occupations more heavily affect Native Germans than manual jobs, service occupations are of greater importance for Naturalised Immigrants and Foreigners especially at high pay deciles. We obtain the highest coefficients of determination for medium to high wage deciles: For Native Germans (27-30 \%), Naturalised Immigrants (32-35 \%) and Foreigners (32-33\%).

20 Table A. 7 of the appendix shows the results of Blinder-Oaxaca decomposition at the mean. Table A. 8 of the appendix provides corresponding results of the UQR-decomposition.

${ }^{21}$ We classify deciles 1 to 3 as low wage deciles, deciles 4 to 6 as middle wage deciles, and deciles 7 to 9 as high wage deciles.
} 
However, the explanatory power of labour market experience is greater for Naturalised Immigrants of high wage deciles whereas for Foreigners it is stronger for low wage deciles.

Regarding wage gap development along quantiles, we obtain results opposing those of Grandner \& Gstach (2015). Our findings demonstrate the advantages of decomposition for unconditional quantile regressions over mean Blinder-Oaxaca decomposition. On one hand, increasing wage gaps along the wage distribution are observed; on the other hand, we find a greater wage disadvantage for low wage deciles that would otherwise have not been discovered. ${ }^{22}$

\section{$<$ Figure 2 about here >}

According to the descriptive statistics (see Table 1 above), the wage gap for Native Germans varies considerably among the immigrant subgroups. The wage gap for ethnic German repatriates has grown almost linearly from 11.7 to 26.8 percent with increasing wage deciles. A comparable distribution for the pay gap can be observed for citizens of Turkey (14.8-30.5\%) and for citizens of the former Yugoslavia (17.7-31.2 \%) with the exception of relatively large gaps for low and high wage deciles. The endowment effect remains at consistently low levels for citizens of Turkey (30-50 \%) and increases for citizens of the former Yugoslavia (50-90 \%) and for ethnic German repatriates (40-80 \%). The wage gap is consistently smaller for citizens of southern European countries (2.4-14.2 \%) and follows a declining course with increasing wages. For lower wage deciles, the explanation accounts for 70 percent and approximately 90 percent for higher pay deciles. The wage differential of naturalised immigrants without ethnic Germans is the smallest of the groups (4.1-7.9\%) and the only group showing a shrinking gap at higher wages. Although the endowment effect reaches shares of roughly 60 percent only, the results imply that naturalised immigrants no longer seem to differ considerably from Native Germans in terms of personal characteristics and payoffs. ${ }^{23}$ Crucial explanatory factors continue to include language proficiency and occupation in high and low services. For naturalised immigrants without ethnic Germans, however, these patterns are less pronounced.

These results may indicate selectivity in naturalisation, i.e., those who are more integrated into the German labour market are more likely to be naturalised. In this respect, von Haaren-Giebel \& Sandner (2016) mention higher levels of integration and language proficiency and higher probabilities of staying for naturalised first-generation immigrants compared to foreigners. Overall, foreigners face stronger labour market entry barriers.

For robustness, we additionally run a RIF-decomposition where the group of Naturalised Immigrants includes foreigners who immigrated during our analysis period. We find no divergent results. The inclusion of part-time workers also leads to only a minimal shift, resulting in a slight narrowing of the wage gap for the lowest deciles (see Figure B. 3 of the appendix). Nonetheless, predominantly widening gaps observed along the wage distribution as the level of explanation increases indicate deficient human capital endowments for immigrants for better-paid occupations. Adding individual job tenure to the base model consistently enhances the explanatory content of wage gaps; however, this may be endogenously driven.

\footnotetext{
${ }^{22}$ For the lower wage deciles, wage gaps may bounded by social security benefits and minimum wages.

${ }^{23}$ For the number of observations for each wage decile, see Table A. 9 of the appendix.
} 


\subsection{EFFECT HETEROGENEITY}

We further illustrate the development of labour market conditions for immigrants over time to reveal potential effects of integration policies on wage differentials. To identify potential changes for different (1) age groups and (2) age cohort effects, we consider three age groups: 25-34 years, 35-44 years, and 45-54 years. We exclude foreigners of the first period who have been naturalized thereafter in order to minimize biases resulting from changes in the group compositions. When interpreting the results, various significant institutional changes should be taken into account for our analysis period. ${ }^{24}$

\subsubsection{Age Groups Over Time}

In considering age groups over time, we equally decompose the wage gap for two periods (1994-1999 and 2010-2015) whereas an interval of 10 years between the two analysis periods is applied to exclude multiple assignments of observations to the same age group. Overall, wage gaps are perceptibly larger for the second period for both immigrant main groups. The growth observed is mainly based on a widening of the lower wage deciles. Wage gaps and explanatory rates, however, vary considerably across immigrant age groups (see Figure 3). Young Foreign workers (25-34 years) are especially affected. Rather, in the first period, the gap increases slightly from -7 to -12 percent along the wage distribution. In the second period, a complete reversal takes place and the wage gap for lower deciles escalates to -16 to -20 percent with an explanatory power value of roughly 90 percent. A different situation is observed for young Naturalised Immigrants whose wage gap rises linearly from -2.5 to -13 percent in the first period (see Figure 3). In the second period, however, the wage gap is reduced to a minimum in the lower deciles ( +1 to $-5 \%$ ) while it rises sharply in the higher deciles (-10 to $-17 \%)$.

\section{$<$ Figure 3 about here $>$}

The wage gaps of both immigrant main groups of 35 to 44 years are for the first interval almost constant along the wage deciles: 15.3 percent for Foreigners and 9.3 percent for Naturalised Immigrants on average (except for the highest deciles). While in the second period the wage gap of lower deciles increases for Foreigners (20-24\%), a continuous decline towards zero is noticeable at the highest wage deciles. The explained proportion of the wage gap decomposition is large for each of the middle deciles (70-90\%). On the other hand, the wage gap for naturalised citizens hardly changes, but a partly strong overestimation due to the endowment effect occurs. The wage gap for 45-54 year-old Foreigners is small at first but increases linearly with higher wages (-6.0 to $-24.5 \%$ ). The overall expansion of the gap towards the second period is valued at 5.5 ppts on average and primarily takes place at the lower end of the wage distribution. Although a slight overestimation emerges, the model shows a high level of explanatory content overall. In the second period, naturalised citizens of this age group present a wage gap of 21 to 25 percent and therefore an increase of 7.5 ppts relative to the first period. The endowment effect levels out at ratios of roughly 75 percent.

\footnotetext{
${ }^{24}$ (1) In 2000, a new citizenship law was introduced in Germany, which abruptly affording a large number of foreigners the right to German citizenship through "birthright citizenship" (Geburtsortsprinzip) and "naturalisation based on a legal entitlement" (Anspruchseinbügerung). (2) From 2003 to 2005, comprehensive labour market reforms (Hartz reforms) were implemented, facilitating flexible forms of employment such as mini-jobs, subcontracted work, and temporary employment while reducing unemployment benefits. (3) In 2007, the "freedom of movement" law (Freizügigkeitsgesetz) was enacted in the Eastern European member states, changing the composition of immigrants entering Germany.
} 
For both immigrant main groups, we predominantly note growing wage gaps and a stronger explanation by individuals' endowments for almost all wage deciles. This indicates that the human capital endowment has deteriorated over time relative to Native Germans. Foreign low-wage earners of all age cohorts are especially affected. Additionally, we observe a shift within the explained part of the wage gap decomposition. For both immigrant main groups, the significance of language proficiency remains high but progressively declines. On the other hand, labour market experience and occupations are increasingly important in explaining the wage gap whereas economic sector affiliations are becoming less and less important (Figure B. 2).

\subsubsection{AGE COHORT EFFECTS}

The analysis of cohort effects requires an adjustment of analysis periods. To ensure an identical composition of age cohorts over time, the ranges of the analysis period and age groups must be harmonized, producing four age cohorts from which a temporal trend can be captured for two. For example, 25- to 34-year-olds of the first period (1996-2005) correspond to 35- to 44-year-olds of the second period (2006-2015).

The first age cohort (aged 45-54 years in period 1) of the two immigrant main groups show a comparatively large wage gap of roughly 20 percent with a small share of endowment effects for lower wage deciles. A consideration of these cohorts for the following period is not possible due to their leaving the sample. The second age cohort (aged 35-44/45-54 years) of both immigrant main groups experiences an overall increase in the wage gap with consistently high levels of explanatory content. The increase is, however, greater for Naturalised Immigrants than it is for Foreigners (see Figure B. 4 and Figure B. 5).

Developments are more extensive for the third age cohort (aged 25-34/35-34 years). While Foreigners undergo a massive increase in the wage gap towards the second period (from 9.2 to $19.9 \%$ for deciles 1 to 7 ) and while the endowment effect rises in terms of its share, the increase is much less pronounced and more differentiated for Naturalised Immigrants. In addition to a minor widening of lower wage deciles, we observe a decline in the wage gap of the higher deciles. Particular attention has to be paid to the fourth and youngest age cohorts (aged 25-34 years in period 2). The group of Foreigners and the group of Naturalised Immigrants present a contrasting picture. Wage convergence to Native Germans is observed for Naturalised Immigrants of the lower wage deciles while this occurs for Foreigners of the higher deciles. The larger wage gaps observed at opposite ends of each wage distribution are characterized by large unexplained shares. The gains of the unexplainable wage gap for young immigrants can be influenced not only by the deterioration of their human capital but also by changes in the age cohort's soft motives and soft skills.

The growth of the wage gap observed towards the second period of each age cohort and especially for Foreigners is worrying. This means that wage disadvantages persist over time and even intensify with age and job tenure. On the other hand, wage gaps of Naturalised Immigrants tend to narrow for later age cohorts. However, it is not clear whether these predominantly negative developments are related to institutional reforms. Furthermore, the influence of the naturalisation process on group compositions cannot be completely ruled out. 


\subsection{The Origins of Educational Degrees}

In testing the transferability of human capital, it is necessary to distinguish whether education was obtained in the immigrant's home country or in Germany (Aldashev et al., 2012; Basilio et al., 2017; Chiswick \& Miller, 2009). We therefore exclude all individuals with a foreign highest vocational or school degree. When these restrictions apply, the immigrant-native wage gap of all immigrant groups diminishes substantially: by approximately 4 ppts for Foreigners and by approximately 6 ppts for Naturalised Immigrants in higher deciles relative to the results of our main model (see Figure 4). The endowment effect of the wage gap for Naturalised Immigrants improves by roughly 20 ppts at the lower and middle pay deciles. For Foreigners, the explained part remains nearly unchanged.

$<$ Figure 4 about here $>$

The results indicate a lower appreciation (or lower quality) of foreign educational degrees compared to those obtained in Germany. For ethnic German repatriates and Turkish citizens, a reduction in the wage gap can be observed whereas the decline is stronger for higher wage classes. In contrast, wage gaps remain almost unchanged for naturalised immigrants without ethnic German, for citizens of the former Yugoslavia and for southern European countries. The unexplained parts of the wage decile decompositions increase along all deciles, and underestimations and overestimations occur at the margins of the wage distribution.

Our results point to the imperfect transferability of human capital across country borders and confirm its relevance in explaining the wage differential between natives and immigrants (Basilio et al., 2017). The scope of alterations in wage differences observed when comparing the full sample to the sample of persons with an education in Germany conform with the results of Aldashev et al. (2012). We therefore can assume that comparable educational qualifications are not appreciated to the same extent. However, restrictions also exist due to a lack of formal recognition of qualifications and due to labour market regulations.

\subsection{Human Capital Quality}

We consider the economic distance between one's home country and Germany at the time of immigration as a cross-country proxy for the quality of foreign schooling and work experience (Coulombe et al., 2014). We assume that the more similar a country is in its level of development to that of Germany, the more equal educational standards are and the more likely a common knowledge base is to form with respect to the level of education. For this purpose, we use the relative gross domestic product per capita (GDP p.c.) and calculate the logarithmic function of the home country's percentage GDP p.c. in terms of Germany's GDP p.c. corrected by the logarithm for Germany's economic distance to itself:

$$
\text { EcoDist }_{i}=\log \left(\frac{G D P p c_{i}}{G D P p c_{G E R}} * 100\right)-2
$$

The logarithm of GDP p.c. is used to denote the marginal return of countries' levels of economic performance on its human capital endowment. The indicator range runs from -2 to infinite whereas values of greater than 0.5 can be classified as a large economic distance. The closer a value is to zero, the smaller the economic distance to the country of origin. Corresponding values of the original differences can be found in Table A. 10. 
In the wage regression, we use the economic distance in absolute terms instead of German writing skills and find a significantly negative influence of larger distances on wages. The share of the explained wage gap remains almost unchanged whereby economic distance becomes the key driver of explanation. An overestimation of the low wage deciles for the group of ethnic German repatriates results in an increased wage gap explanation for Naturalised Immigrants (see Figure 5). For robustness, we alternatively use the “Human Capital Index” (HCI) provided by the World Bank as the absolute distance to Germany. The index measures the amount of human capital that a child born today can expect to achieve by age 18 based on risks of poor health and poor education that prevail in the country in which she lives. The HCI scale runs from 0 (insufficient) to 1 (comprehensive) (The World Bank, 2018). The HCI confirms the validity of GDP p.c. as an indicator for the quality of foreign schooling and work experience.

$<$ Figure 5 about here >

\subsection{PERsonality Traits}

To investigate potential differences in personality composition, we consider the 5-factor model of personality (Big Five) in our analysis for 2005 to 2015. Individual personality traits were recorded for 2005, 2009, and 2013. Due to the consistency of personality over time, we perform a linear interpolation, providing us with more stable results. We determine whether an individuals' personality has an impact on his or her salary. Upon comparing the sample with Big Five personality traits to the same sample without these personality variables, the decomposition reveals no significant change in the endowment effect (see Figure 6). This finding is supported by results of an OLS regression showing only a partly significant influence of the Big Five on wages with no change in explanatory power. When considering the Big Five without further control variables, wage gap decompositions show that personality traits have even less of an effect than the comparative model. On the other hand, the corresponding wage regression shows significant influence of certain dimensions of Big Five. We therefore cannot confirm the influence of the Big Five as recognized by Brenzel \& Laible (2016), who control for similar characteristics. This result may be attributed to the indirect effect of personality on wages. Since personality traits determine educational success and later fields of activity, they may be of minor importance to the analysis at hand.

\section{$<$ Figure 6 about here >}

\subsection{Cultural Distance}

Finally, as a final channel of influence, we examine potential barriers to integration by considering metrics of immigrants’ proximity to Germany based on their home countries’ levels of cultural distance. From social norms in the labour market (e.g., work behaviour), it can be assumed that a strongly divergent culture of immigrants partly induces reservations from which personnel decisions may be influenced negatively. While cultural distance shows a consistently significant negative impact on the wages of Naturalised Immigrants, the negative impact on Foreigners' wages is significant only for low wage deciles. In applying cultural distance to the wage gap decomposition, however, we respectively recognize an overestimation of Foreigners' and Naturalised Immigrants' endowment effects for the lower and upper ends of the wage distribution in contrast to the main model (see Figure 7). When we use cultural distance without further 
control variables, a strong explanation rate emerges for Foreigners, but not for Naturalised Immigrants. Therefore, it can be concluded that the wage differences of Foreigners may be attributed to their original culture to a certain extent.

\section{$<$ Figure 7 about here $>$}

\section{CONCLUSION}

The assimilation of immigrants' wage levels with natives' wage levels serves as an important indicator of labour market integration. We therefore analysed wage differentials between native Germans and two immigrant groups, Foreigners and Naturalised Immigrants, by applying Blinder-Oaxaca decomposition for unconditional quantile regression (UQR) models as recommended by Firpo et al. (2009). This approach allowed us to divide wage differences into observable and unobserved factors of influence along the entire wage distribution.

The wage gap decompositions reveal a significantly growing wage gap with higher deciles for Foreigners (10.0-16.4\%) and Naturalised Immigrants (13.6-17.6\%) for the years 1994 to 2015. Differences in individuals' characteristics and work-related factors (endowment effect) can thereby explain roughly 80 percent of Foreigners' wage gap. For Naturalised Immigrants, the endowment effect increases from 50 to 100 percent along the wage distribution, implying that a large proportion of the wage gap for low wage deciles remains unexplained due to unobserved factors (coefficient effect). Our results therefore infer certain wage disadvantages for people with a migration background. Language proficiency and occupation in high and low services and especially in high wage deciles are the main determinants of the wage gap for both immigrant groups (Naturalised Immigrants and Foreigners). In contrast, the explanatory content of education is only slightly positive.

Moreover, we can identify heterogeneity of the wage gaps of further ethnic subgroups relative to native Germans: foreigners from Turkey and the former Yugoslavia as well as ethnic German repatriates have suffered a stronger wage disadvantage than southern European citizens. Again, inadequate language skills can partly explain these gaps. Our results furthermore indicate a limited degree of human capital transferability or at least a lower appreciation of foreign educational degrees. The estimated wage gap for persons graduating in Germany is smaller at approximately 4 to 6 ppts relative to the results of the basic model. When testing for human capital quality applying the economic distance between the host and home country, the influence goes hand in hand with language skills. When taking the home country's cultural distance to Germany into account, we recognize no changes in the endowment effect. Contrary to our expectations, we also find no significant influence of personal traits (Big Five).

We further determined whether immigrant wage differences might be affected by different reforms concerning the labour market. Foreigners' average wage gap rise over time mainly due to a broadening of lower wage deciles in all age cohorts whereas the increase in the average wage gap for Naturalised Immigrants has been driven by the oldest workers. Age cohort results confirm an increase in wage gaps over time, especially for Foreigners. On the other hand, the wage gaps of Naturalised Immigrants tend to narrow in later age cohorts. In addition, we predominantly ascertain a stronger explanation from 
individuals' endowment and labour market characteristics showing that the human capital endowments of immigrants has deteriorated towards native Germans over time and with more recent immigration cohorts.

Previous public and private programmes for the social and economic integration of migrants in Germany are proving to be insufficient in effectively tackling this long-term challenge. A stronger recognition of foreign educational qualifications would favour career decisions made based on actual qualifications while fully exploiting existing and future labour force potential and lessening economic inefficiencies. Moreover, an improvement in immigrants labour market prospects could be precipitated by adjusting vocational training, which so far has been predominantly oriented towards labour market entry (extensive margins) rather than towards the activation of individual performance potential (intensive margins). Nonetheless, immigrants' efforts towards labour market integration must be continued to improve immigrants' prospects and to diminish the social disadvantaging and rejection of ethnic groups.

\section{ACKNOWLEDGEMENTS}

We are grateful to Jens Ruhose (University of Hannover), Stefan Bauernschuster (University of Passau) and Thomas Lemieux (University of British Columbia) for their helpful comments. We would also like to thank lecture participants of the 2018 annual conference of the Verein für Socialpolitik (VfS) and of the 2019 FRIAS Junior Researcher Conference for their comments.

\section{REFERENCES}

Adsera, A., \& Chiswick, B. R. (2007). Are there gender and country of origin differences in immigrant labor market outcomes across European destinations? Journal of Population Economics, 20(3), 495-526.

Aldashev, A., Gernandt, J., \& Thomsen, S. L. (2009). Language usage, participation, employment and earnings. Evidence for foreigners in West Germany with multiple sources of selection. Labour Economics, 16(3), 330-341.

Aldashev, A., Gernandt, J., \& Thomsen, S. L. (2012). The Immigrant-Native Wage Gap in Germany. Journal of Economics and Statistics, 232(5), 490-517.

Algan, Y., Dustmann, C., Glitz, A., \& Manning, A. (2010). The Economic Situation of First and SecondGeneration Immigrants in France, Germany and the United Kingdom. Economic Journal, 120, 430.

Altonji, J. G., \& Blank, R. M. (1999). Race and gender in the labor market. In O. Ashenfelter \& D. Card (Eds.), Handbook of Labor Economics (vol. 3, pp. 3143-3259). Amsterdam: Elsevier Science B.V.

Antonczyk, D., Fitzenberger, B., \& Sommerfeld, K. (2010). Rising wage inequality, the decline of collective bargaining, and the gender wage gap. Labour Economics, 17(5), 835-847.

Aydemir, A., \& Skuterud, M. (2008). The Immigrant Wage Differential within and across Establishments. ILR Review, 61(3), 334-352.

Bartolucci, C. (2014). Understanding the Native-Immigrant Wage Gap Using Matched EmployerEmployee Data: Evidence from Germany. ILR Review, 67(4), 1166-1202.

Basilio, L., Bauer, T. K., \& Kramer, A. (2017). Transferability of Human Capital and Immigrant Assimilation: An Analysis for Germany. Labour, 31(3), 245-264.

Battisti, M., Peri, G., \& Romiti, A. (2018). Dynamic effects of Co-ethnic Networks on Immigrants' Economic Success (CESifo Working Paper No. 7084). Munich.

Biewen, M., \& Juhasz, A. (2012). Understanding Rising Income Inequality in Germany, 1999/20002005/2006. Review of Income and Wealth, 58(4), 622-647. 
Biewen, M., Ungerer, M., \& Löffler, M. (2017). Why Did Income Inequality in Germany Not Increase Further After 2005? German Economic Review, 1-34.

Borjas, G. J. (1985). Assimilation, Changes in Cohort Quality, and the Earnings of Immigrants. Journal of Labor Economics, 3(4), 463-489.

Borjas, G. J. (2015). The Slowdown in the Economic Assimilation of Immigrants: Aging and Cohort Effects Revisited Again. Journal of Human Capital, 9(4), 483-517.

Brenzel, H., \& Laible, M.-C. (2016). Does personality matter? The impact of the Big Five on the migrant and gender wage gaps (IAB-Discussion Paper, No. 26/2016). Nuremberg.

Brynin, M., \& Güveli, A. (2012). Understanding the ethnic pay gap in Britain. Work, Employment and Society, 26(4), 574-587.

Busato, V. V, Prins, F. J., Elshout, J. J., \& Hamaker, C. (1999). The relation between learning styles, the Big Five personality traits and achievement motivation in higher education. Personality and Individual Differences, 26, 129-140.

Canal-Domínguez, J. F., \& Rodríguez-Gutiérrez, C. (2008). Analysis of wage differences between native and immigrant workers in Spain. Spanish Economic Review, 10, 109-134.

Card, D., Heining, J., \& Kline, P. (2013). Workplace heterogeneity and the rise of West German wage inequality. The Quarterly Journal of Economics, 128(3), 967-1015.

Chiswick, B. R. (1978). The Effect of Americanization on the Earnings of Foreign-born Men. Journal of Political Economy, 86(5), 897-921.

Chiswick, B. R., \& Miller, P. W. (2009). The international transferability of immigrants' human capital. Economics of Education Review, 28(2), 162-169.

Christl, M., Köppl-Turyna, M., \& Gnan, P. (2018). Wage differences between immigrants and natives in Austria: The role of literacy skills (Annual Conference 2018, Verein für Socialpolitik). Freiburg.

Constant, A. F., \& Massey, D. S. (2005). Labor market segmentation and the earnings of German guestworkers. Population Research and Policy Review, 24(5), 489-512.

Coulombe, S., Grenier, G., \& Nadeau, S. (2014). Human capital quality and the immigrant wage gap. IZA Journal of Migration, 3(14).

Danzer, A. M., \& Yaman, F. (2016). Ethnic concentration and language fluency of immigrants: Evidence from the guest-worker placement in Germany. Journal of Economic Behavior and Organization, 131, 151-165.

DIW. (2017). German Socio Economic Panel (SOEP), German Institute for Economic Research, Berlin. Retrieved from http://www.diw.de/de/soep

Dustmann, C., Ludsteck, J., \& Schönberg, U. (2009). Revisting the German Wage Structure. The Quarterly Journal of Economics, 124(2), 843-881.

Dustmann, C., \& Van Soest, A. (2002). Language and the Earnings of Immigrants. ILR Review, 55(3), 473-492.

Eurostat. (2018a). Bevölkerung am 1. Januar nach Altersgruppen, Geschlecht und Staatsangehörigkeit [migr_pop1ctz]. Retrieved from http://ec.europa.eu/eurostat/de/data/database

Eurostat. (2018b). Einwanderung nach Alter und Geschlecht [migr_imm8]. Retrieved from http://ec.europa.eu/eurostat/de/data/database

Federal Agency for Civic Education. (2005). Zwangswanderungen nach dem Zweiten Weltkrieg. Retrieved from http://www.bpb.de/gesellschaft/migration/dossier-migration/56359/nach-dem-2weltkrieg

Federal Agency for Civic Education. (2012). Geschichte der Zuwanderung nach Deutschland nach 1950. Retrieved from http://www.bpb.de/politik/grundfragen/deutsche-verhaeltnisse-einesozialkunde/138012/geschichte-der-zuwanderung-nach-deutschland-nach-1950?p=all

Federal Bureau of Statistics. (2017a). Bevölkerung mit Migrationshintergrund - Ergebnisse des Mikrozensus 2016. Retrieved from https://www.destatis.de/DE/Themen/GesellschaftUmwelt/Bevoelkerung/Migration-Integration/_inhalt.html\#sprg228898 
Federal Bureau of Statistics. (2017b). Different publications. Retrieved from https://www.destatis.de/DE/Publikationen/Thematisch/ThematischeVeroeffentlichungen.html

Federal Employment Agency. (2017). Different publications. Retrieved from https://statistik.arbeitsagentur.de/Navigation/Statistik/Statistik-nach-Themen/Statistik-nachThemen-Nav.html

Federal Government. (2016). Darstellung der Maßnahmen der Bunderegierung für die Sprachförderung und Integration von Flüchtlingen. Retrieved from https://www.bmas.de/SharedDocs/Downloads/DE/PDF-Publikationen/massnahmen-derbundesregierung-fuer-sprachfoerderung-und-integration-vonfluechtlingen.pdf;jsessionid=35EEA0470547E2E22E267EAC7974BA99?__blob=publicationFile\& $\mathrm{v}=2$

Federal Office of Adminstration. (2017). Statistiken zur Aussiedleraufnahmeverfahren, Zeitreihen. Retrieved from http://www.bva.bund.de/DE/Organisation/Abteilungen/Abteilung_BT/Spaetaussiedler/statistik/Stati stik_dossier.html?nn=4487700\&notFirst=true\&docId=5457198

Felfe, C., Kocher, M. G., Rainer, H., Saurer, J., \& Siedler, T. (2019). More Opportunity, More Cooperation? The Behavioral Effects of Birthright Citizenship on Immigrant Youth (forthcoming). Retrieved from https://www.eui.eu/Documents/DepartmentsCentres/Economics/Seminarsevents/paper-Felfe.pdf

Fertig, M., \& Schurer, S. (2007). Earnings Assimilation of Immigrants in Germany: The Importance of Heterogeneity and Attrition Bias (SOEPpapers on Multidisciplinary Panel Data Research, No. 30). Berlin.

Firpo, S., Fortin, N. M., \& Lemieux, T. (2009). Unconditional Quantile Regressions. Econometrica, 77(3), 953-973.

Firpo, S., Fortin, N. M., \& Lemieux, T. (2018). Decomposing Wage Distributions using Recentered Influence Functions Regressions. Econometrics, 6, 1-40.

Fortin, N. M. (n.d.). RIF-Regression STATA ado file from Firpo, Fortin and Lemieux (2009). Retrieved from https://faculty.arts.ubc.ca/nfortin/datahead.html

Fortin, N. M., Lemieux, T., \& Firpo, S. (2011). Decomposition Methods in Economics. In Handbook of Labor Economics (Vol. 4a, pp. 1-102). Elsevier Inc.

Fortin, N. M., Lemieux, T., \& Torres, J. (2016). Foreign human capital and the earnings gap between immigrants and Canadian-born workers. Labour Economics, 41, 104-119.

Galego, A., \& Pereira, J. (2014). Decomposition of regional wage differences along the wage distribution in Portugal: the importance of covariates. Environment and Planning A, 46(10), 2514-2532.

Gathmann, C., \& Keller, N. (2018). Access to Citizenship and the Economic Assimilation of Immigrants. The Economics of Immigration and Social Diversity Economic Journal, 128(616), 3141-3181.

German Bundestag. (2014). Wissenschaftliche Dienste. Die Öffnung des Eisernen Vorhangs in Ungarn vor 25 Jahren. Retrieved from https://www.bundestag.de/blob/284868/654febe89239fbc8a266bc1202acad84/die-oeffnung-deseisernen-vorhangs-in-ungarn-vor-25-jahren-data.pdf

Gernandt, J., \& Pfeiffer, F. (2007). Rising Wage Inequality in Germany. Journal of Economics and Statistics, 227(4), 358-380.

Giesecke, J., \& Verwiebe, R. (2009). The Changing Wage Distribution in Germany between 1985 and 2006. In Schmollers Jahrbuch (Vol. 129, pp. 191-201). Berlin: Duncker \& Humblot.

Goebel, J., Grabka, M. M., Liebig, S., Kroh, M., Richter, D., Schröder, C., \& Schupp, J. (2019). The German Socio-Economic Panel (SOEP). Journal of Economics and Statistics, 239(2), 345-360.

Grandner, T., \& Gstach, D. (2015). Decomposing wage discrimination in Germany and Austria with counterfactual densities. Empirica, 42, 49-76.

Gundel, S., \& Peters, H. (2008). What determines the duration of stay of immigrants in Germany?: Evidence from a longitudinal duration analysis. International Journal of Social Economics, 35(11), 
769-782.

Guven, C., \& Islam, A. (2015). Age at Migration, Language Proficiency, and Socioeconomic Outcomes: Evidence From Australia. Demography, 52(2), 513-542.

Heineck, G., \& Anger, S. (2010). The returns to cognitive abilities and personality traits in Germany. Labour Economics, 17(3), 535-546.

Hochman, O., \& Davidov, E. (2014). Relations between Second-Language Proficiency and National Identification: The Case of Immigrants in Germany. European Sociological Review, 30(3), 344349.

Hofer, H., Titelbach, G., Winter-Ebmer, R., \& Ahammer, A. (2017). Wage Discrimination Against Immigrants in Austria? Labour, 31(2), 105-126.

Hofstede, G. (1980). Culture's Consequences: International Differences in Work-related Values. Beverly Hills, CA: Sage Publications.

Isphording, I. E., \& Otten, S. (2014). Linguistic barriers in the destination language acquisition of immigrants. Journal of Economic Behavior and Organization, 105, 30-50.

Jann, B. (2008). Erwerbsarbeit, Einkommen und Geschlecht. Wiesbaden: VS Verlag für Sozialwissenschaften.

John, K., \& Thomsen, S. L. (2014). Heterogeneous returns to personality: The role of occupational choice. Empirical Economics, 47(2), 553-592.

Kaasa, A., Vadi, M., \& Varblane, U. (2016). A new dataset of cultural distances for European countries and regions. Research in International Business and Finance, 37, 231-241.

Kanas, A., Chiswick, B. R., Van Der Lippe, T., \& Van Tubergen, F. (2012). Social Contacts and the Economic Performance ofImmigrants: A Panel Study ofImmigrants in Germany. International Migration Review, 46(3), 680-709.

Kogan, I. (2011). New Immigrants - Old Disadvantage Patterns? Labour Market Integration of Recent Immigrants into Germany. International Migration, 49(1), 91-117.

Kosyakova, Y., \& Sirries, S. (2017). Large-Scale Immigration and Labour Market Integration: First Lessons from the Recent Past in Germany. Intereconomics, 52(5), 263-269.

Lehmer, F., \& Ludsteck, J. (2011). The Immigrant Wage Gap in Germany: Are East Europeans Worse Off? International Migration Review, 45(4), 872-906.

Lehmer, F., \& Ludsteck, J. (2015). Wage Assimilation of Foreigners: Which Factors Close the Gap? Evidence From Germany. Review of Income and Wealth, 61(4), 677-701.

Longhi, S. (2017). Spatial-Ethnic Inequalities: The Role of Location in the Estimation of Ethnic Wage Differentials (IZA Discussion Paper Series No. 11073). Bonn.

Ñopo, H. (2008). Matching as a tool to decompose wage gaps. Review of Economics and Statistics, 90(2), 290-299.

O’Neill, J. E., \& O’Neill, D. M. (2015). What do wage differentials tell about labor market discrimination? In S. W. Polachek, C. Chiswick, \& H. Rapoport (Eds.), The Economics of Immigration and Social Diversity (24th ed., pp. 293-357). Emerald Group Publishing Limited.

OECD. (2013). Discrimination against immigrants - measurement, incidence and policy instruments. In International Migration Outlook 2013 (pp. 191-230). Paris: OECD Publishing.

Peri, G., \& Sparber, C. (2009). Task Specialization, Immigration, and Wages. American Economic Journal: Applied Economics, 1(3), 135-169.

Riphahn, R. T., Sander, M., \& Wunder, C. (2013). The welfare use of immigrants and natives in Germany: The case of Turkish immigrants. International Journal of Manpower, 34(1), 70-82.

Roth, B., Hahn, E., \& Spinath, F. M. (2017). Income Inequality, Life Satisfaction, and Economic Worries. Social Psychological and Personality Science, 8(2), 133-141.

Schmidt, C. M. (1997). Immigrant Performance in Germany: Labor Earnings of Ethnic German Migrants and Foreign Guest-Workers. The Quarterly Review of Economics and Finance, 37(Special Issue), 
379-397.

Simón, H. (2010). International Differences in Wage Inequality: A New Glance with European Matched Employer-Employee Data. British Journal of Industrial Relations, 48(2), 310-346.

Sola, A. (2018). The 2015 Refugee Crisis in Germany: Concerns about Immigration and Populism (SOEPpapers on Multidisciplinary Panel Data Research No. 966). Berlin.

The World Bank. (2018). The Human Capital Index (HCI). Retrieved from https://datacatalog.worldbank.org/dataset/human-capital-index

Thiel, H., \& Thomsen, S. L. (2013). Noncognitive skills in economics: Models, measurement, and empirical evidence. Research in Economics, 67(2), 189-214.

Tverdostup, M., \& Paas, T. (2017). The Role of Cognitive Skills and Their Use at Work in Explaining the Immigrant-Native Wage Gap (University of Tartu FEBA Working Papers). Tartu.

United Nations Statistics Division (UNSD). (2017). Per Capita GDP at constant 2010 prices in US

Dollars (all countries), 1970-2016. Retrieved from

https://unstats.un.org/unsd/snaama/dnltransfer.asp?fID=12

von Haaren-Giebel, F., \& Sandner, M. (2016). Naturalisation and on-the-job training: evidence from firstgeneration immigrants in Germany. IZA Journal of Migration, 5(19), 1-28.

Warman, C., Sweetman, A., \& Goldmann, G. (2015). The Portability of New Immigrants’ Human Capital: Language, Education, and Occupational Skills. Canadian Public Policy, 41, 64-79. 


\section{FIGURES AND TABLES}

Figure 1: Ratio of immigrants’ mean log hourly wages relative to native Germans

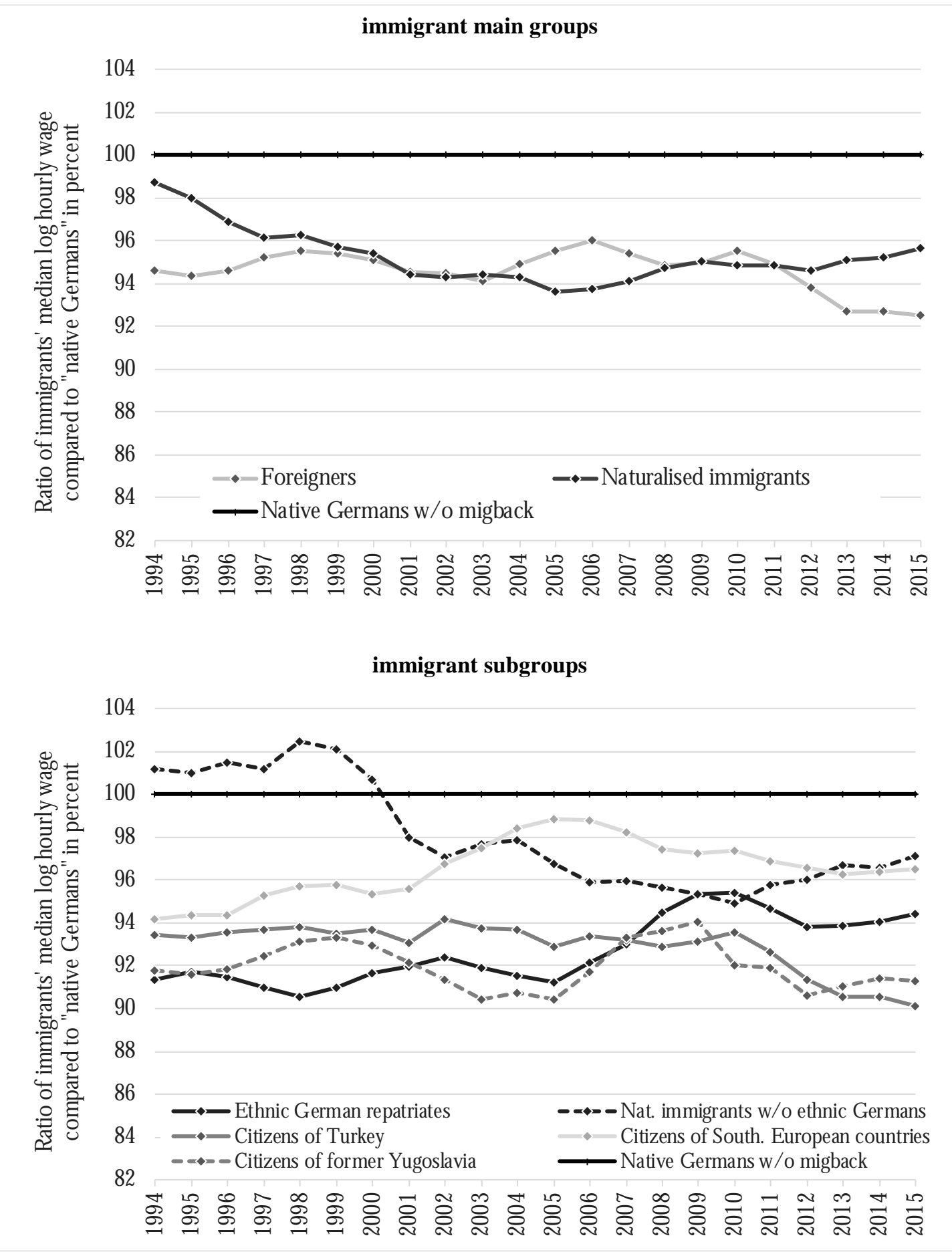

Source: DIW (2017). Own calculations. Survey weights are integrated to counteract sample bias. Mean wages are smoothed with adjacent years. 
Table 1: Means of select characteristics (pooled for 1994 to 2015) ${ }^{\text {a }}$

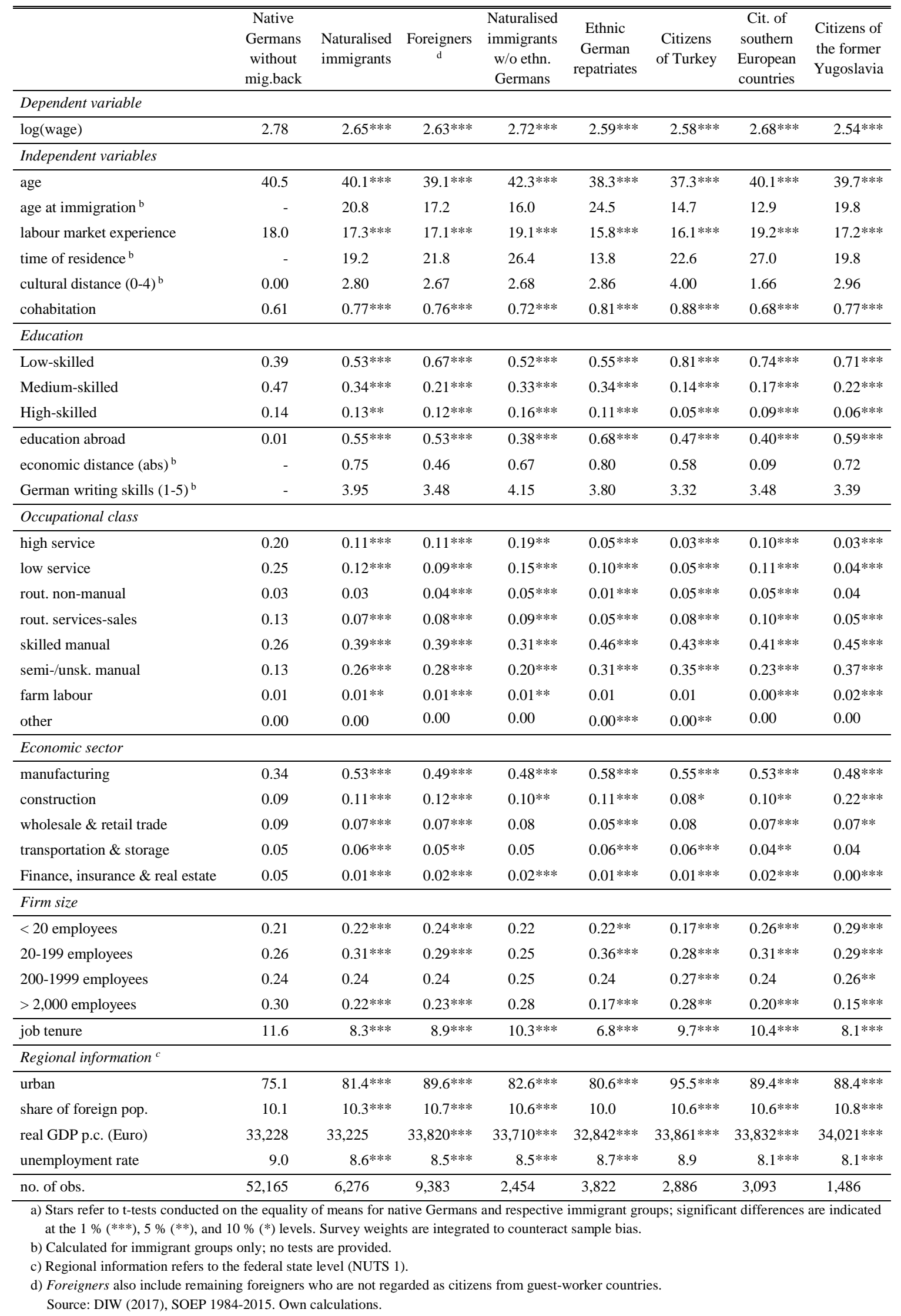


Figure 2: Blinder-Oaxaca wage decomposition for UQR (1994-2015)

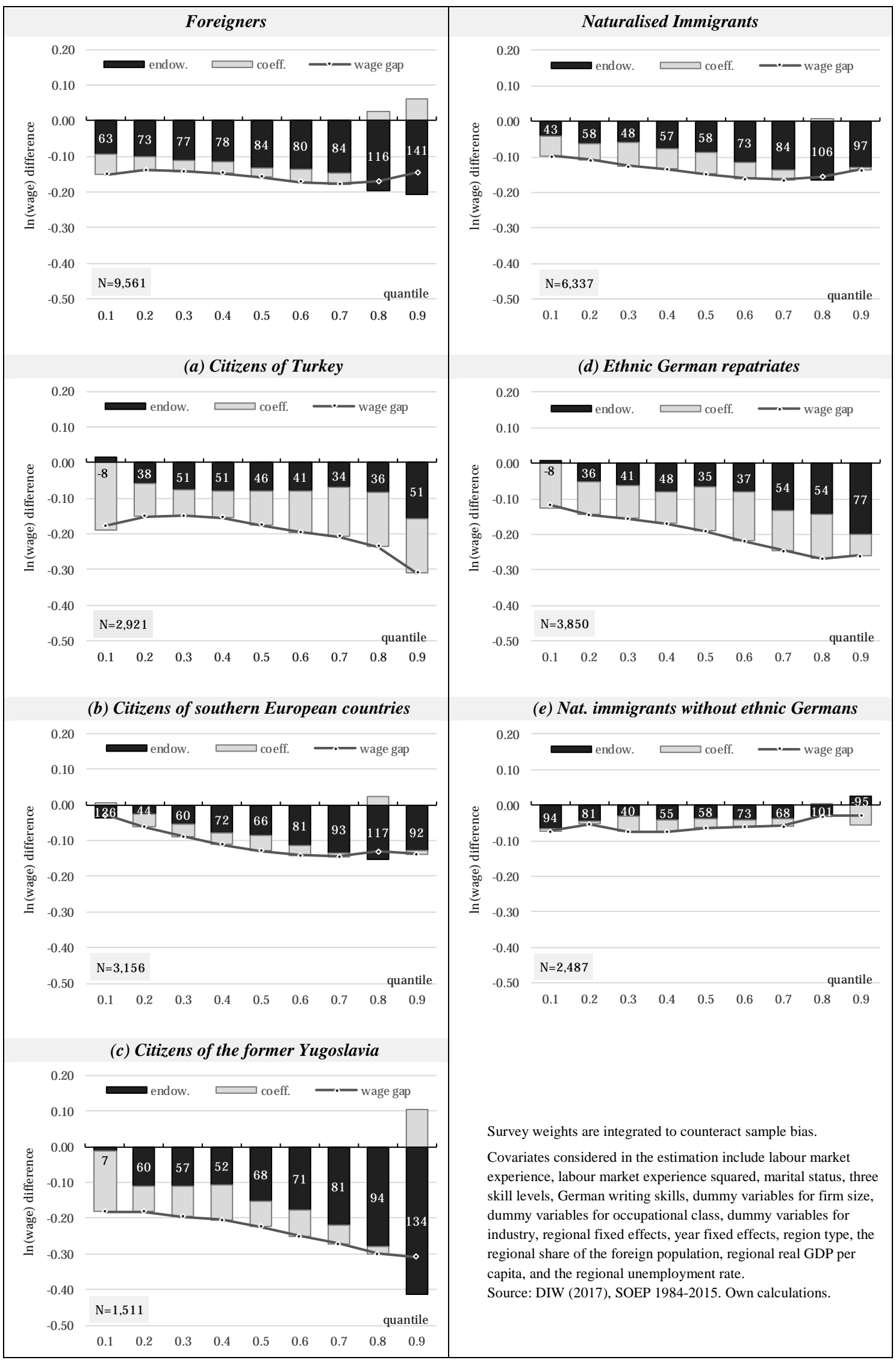


Figure 3: Blinder-Oaxaca wage decomposition for UQR (1994-1999 and 2010-2015)

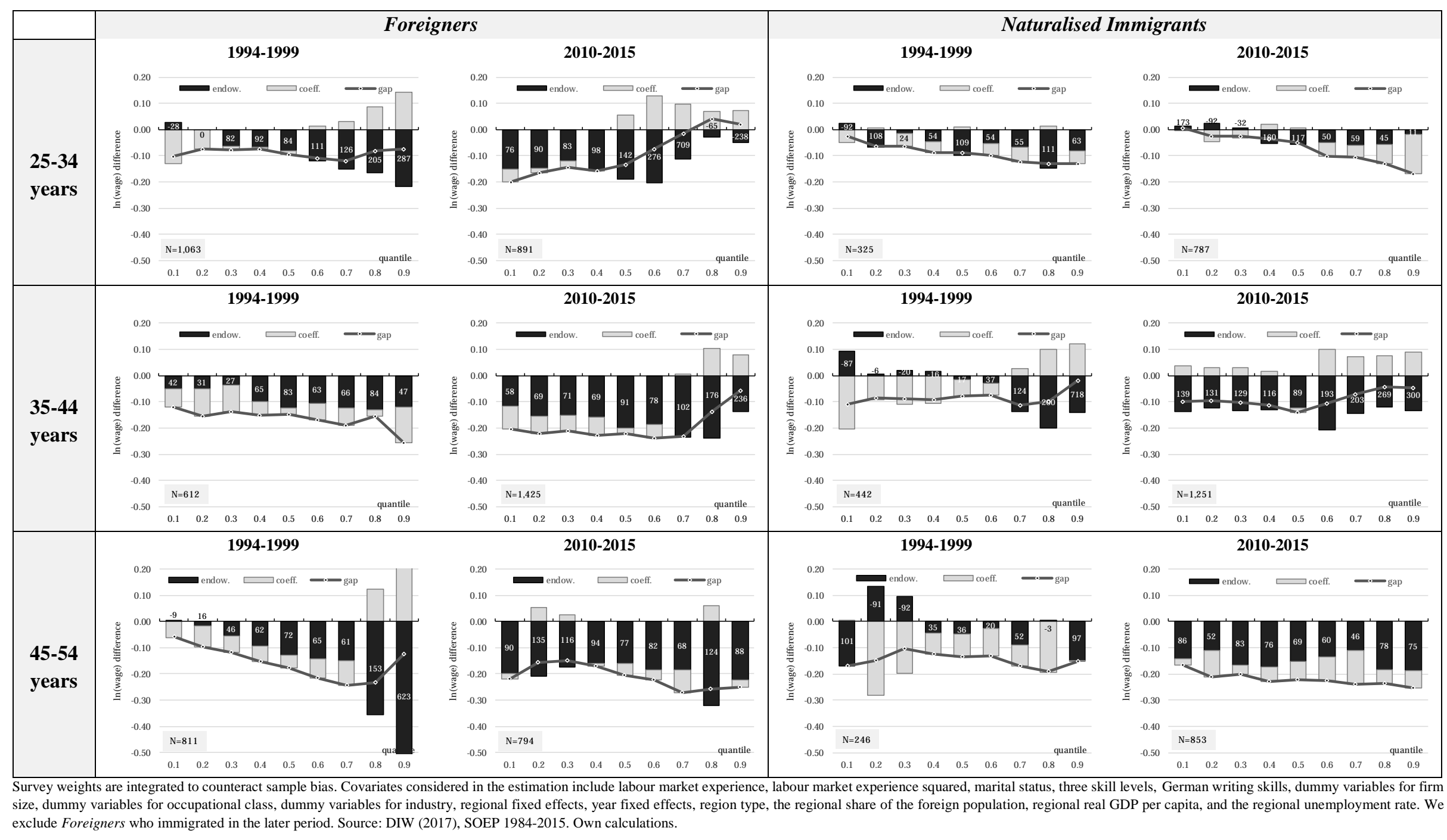


Figure 4: Blinder-Oaxaca wage decomposition for UQR (1994-2015) - educational degree completed in Germany

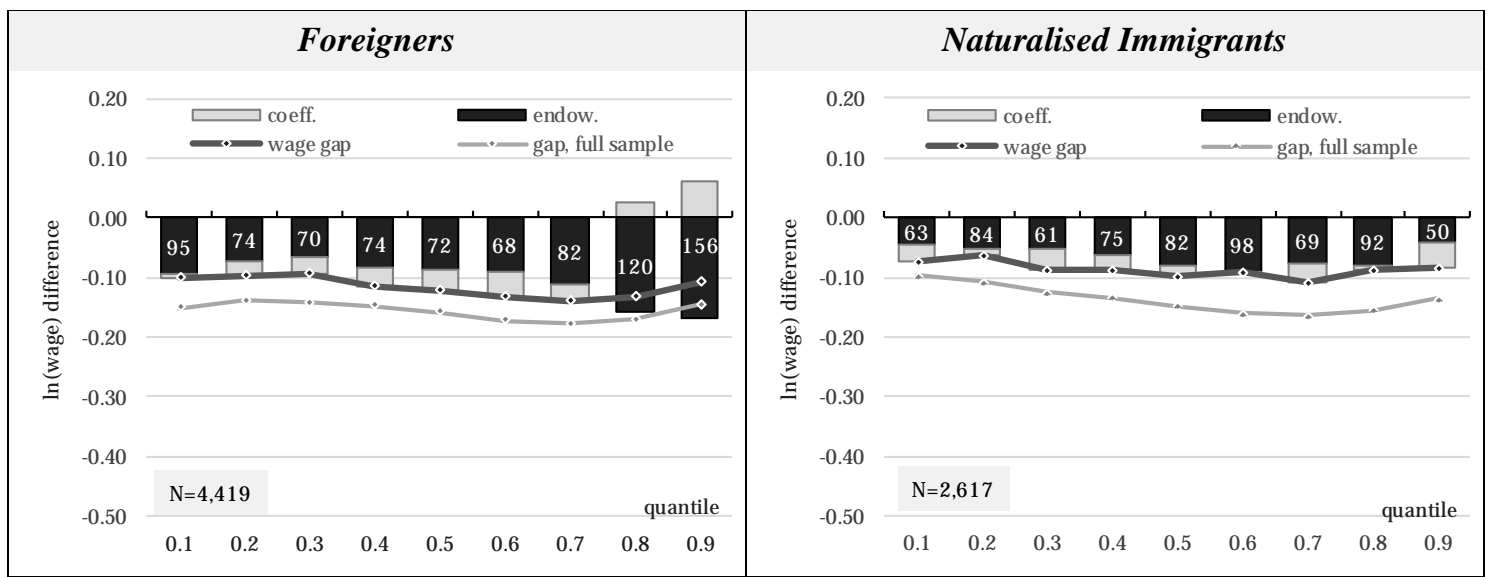

Survey weights are integrated to counteract sample bias. Covariates considered in the estimation include labour market experience, labour market experience squared, marital status, three skill levels, dummy variables for firm size, dummy variables for occupational class, dummy variables for industry, regional fixed effects, year fixed effects, region type, the regional share of the foreign population, regional real GDP per capita, and the regional unemployment rate.

Source: DIW (2017), SOEP 1984-2015. Own calculations.

Figure 5: Blinder-Oaxaca wage decomposition for UQR (1994-2015) - Human Capital Quality

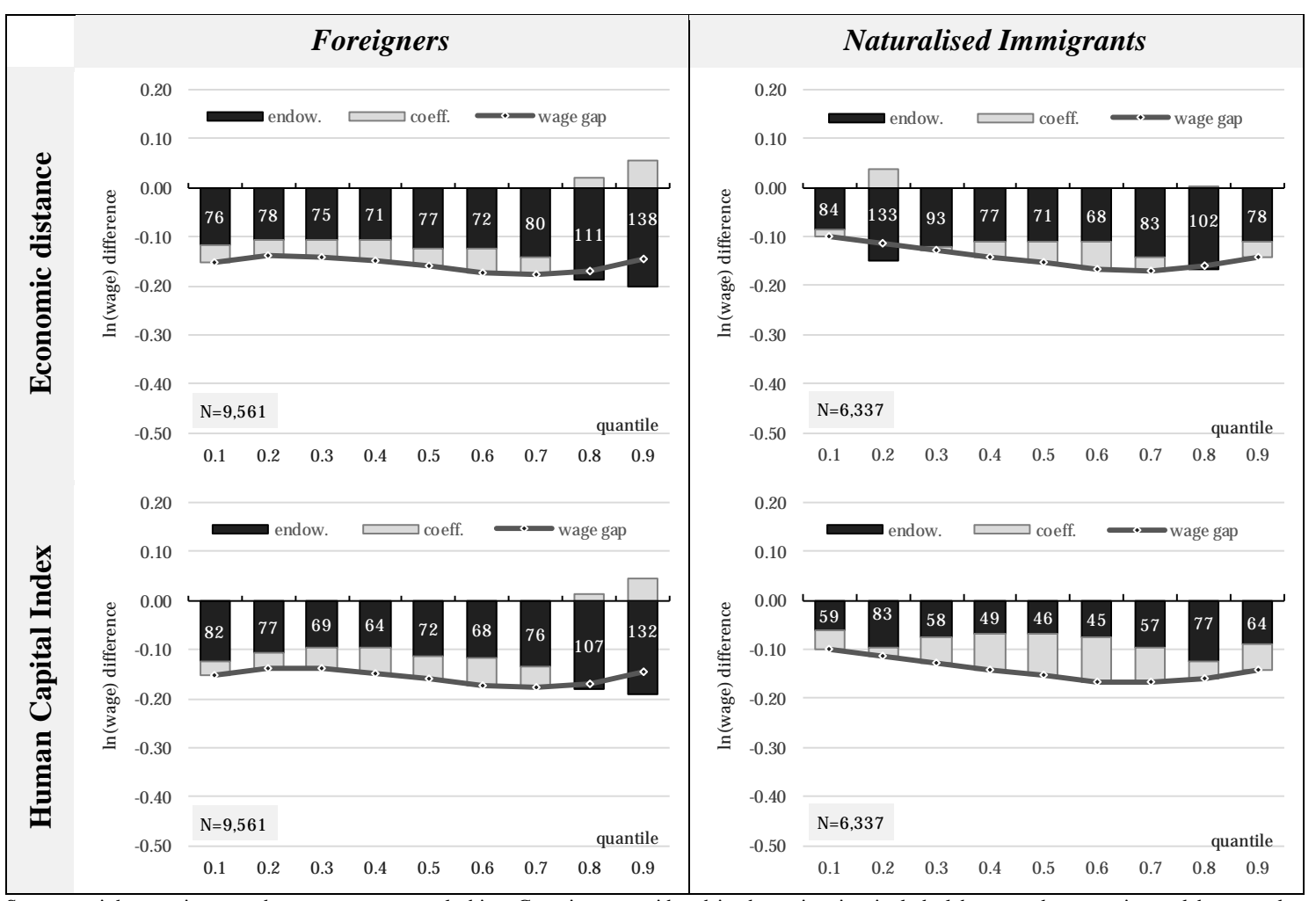

Survey weights are integrated to counteract sample bias. Covariates considered in the estimation include labour market experience, labour market experience squared, marital status, three skill levels, dummy variables for firm size, dummy variables for occupational class, dummy variables for industry, regional fixed effects, year fixed effects, region type, the regional share of the foreign population, regional real GDP per capita, and the regional unemployment rate.

Source: DIW (2017), SOEP 1984-2015. Own calculations. 
Figure 6: Blinder-Oaxaca wage decomposition for UQR (2005-2015) - Personality Traits

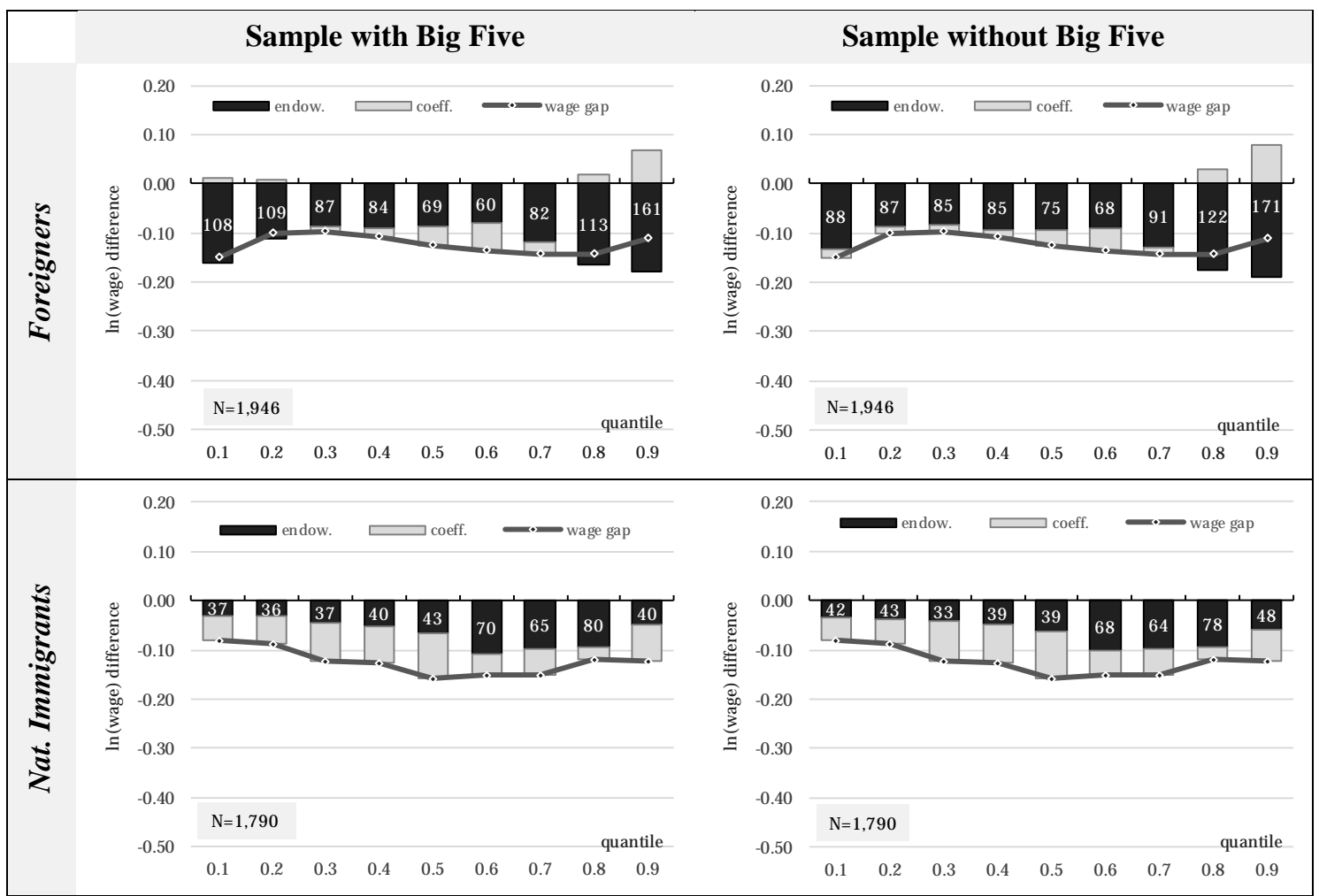

Survey weights are integrated to counteract sample bias. Covariates considered in the estimation include labour market experience, labour market experience squared, marital status, three skill levels, German writing skills, dummy variables for firm size, dummy variables for occupational class, dummy variables for industry, regional fixed effects, year fixed effects, region type, the regional share of the foreign population, regional real GDP per capita, and the regional unemployment rate. Source: DIW (2017), SOEP 1984-2015. Own calculations.

Figure 7: Blinder-Oaxaca wage decomposition for UQR (1994-2015) - Cultural Distance

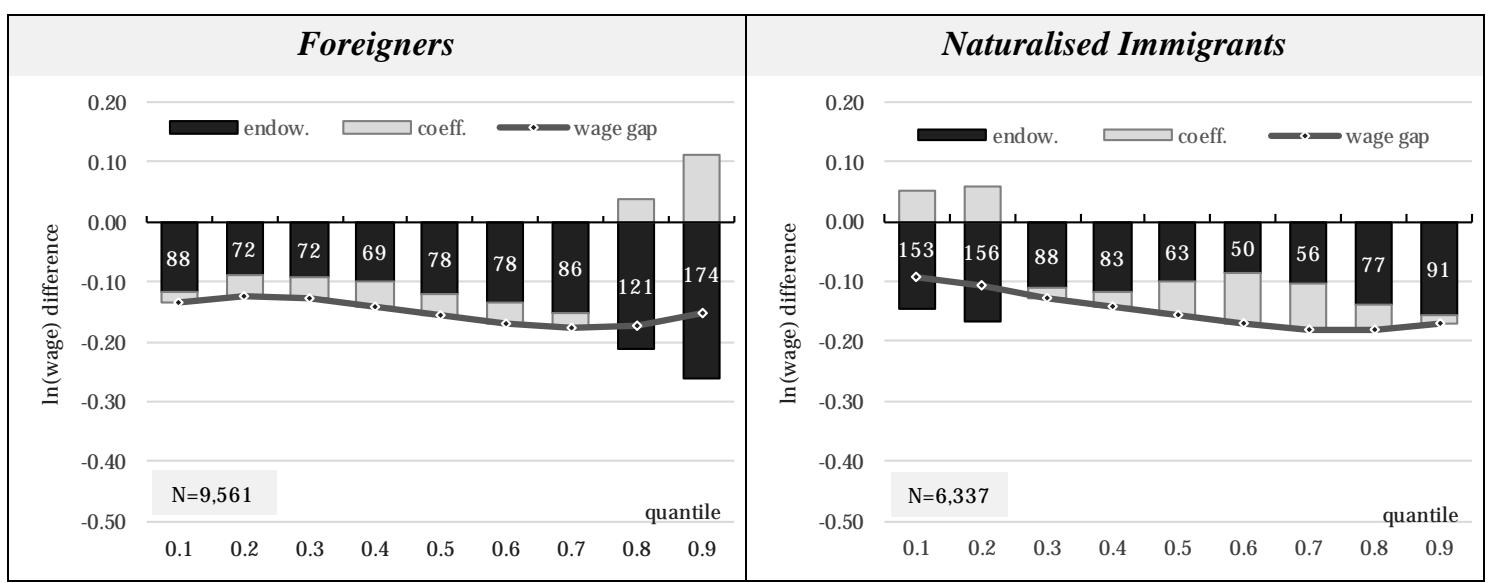

Survey weights are integrated to counteract sample bias. Covariates considered in the estimation include labour market experience, labour market experience squared, marital status, three skill levels, dummy variables for firm size, dummy variables for occupational class, dummy variables for industry, regional fixed effects, year fixed effects, region type, the regional share of the foreign population, regional real GDP per capita, and the regional unemployment rate.

Source: DIW (2017), SOEP 1984-2015. Own calculations. 


\section{APPENDIX}

A. Tables

Table A. 1: Description of defined variables

\begin{tabular}{|c|c|}
\hline variable lable & variable explanation \\
\hline $\log ($ wage $)$ & $\begin{array}{l}\text { Gross wages per month devided real working hours per week; extrapolated to } \\
\text { monthly hours ( } 365.25 \text { days/ year }=30.44 \text { days } / \text { month }=4.35 \text { weeks } / \text { month })\end{array}$ \\
\hline time of residence & "year of survey" minus "year of immigration" to G emany. \\
\hline age & "year of survey" minus "year of birth". \\
\hline labour market experience & $\begin{array}{l}\text { labour market experience "full time" }+0.625 * \text { labour market experience "part } \\
\text { time". Part-time generally can be devided into "near to full-time" (ca. 30h/ week) } \\
\text { and "far from full-time" (ca. 20h/ week). }\end{array}$ \\
\hline cohabitation & D ummy: $0=$ living without partner, $1=$ living in a partnership \\
\hline low-skilled & $\begin{array}{l}\text { CASMIN educational classification: (1a) inadequately completed, (1b) general } \\
\text { elementary school, (1c) basic vocational qualification, (2b) intermediate general } \\
\text { qualification }\end{array}$ \\
\hline medium-skilled & $\begin{array}{l}\text { CASMIN educational classification: (2a) intermediate vocational qualification, } \\
\text { (2c_gen) general maturity certificate, (2c_voc) vocational maturity certificate, (3a) } \\
\text { lower tertiary education }\end{array}$ \\
\hline high-skilled & CASMIN educational classification: (3b) higher tertiary education \\
\hline education abroad & Vocational degree or school-leaving degree outside G ermany \\
\hline German writing skills & $\begin{array}{l}\text { Self-assessment of the writing skills via scores from } 1 \text { (not at all) to } 5 \text { (very good). } \\
\text { Linear interpolation of missing values. }\end{array}$ \\
\hline Cultural distance & Adopted by Kaasa et al. (2016) and classified into five groups. \\
\hline Economics distance & $\begin{array}{l}\text { Distances based on per Capita GDP at constant } 2010 \text { prices in US D ollars. } \\
\text { Logarithmic function of home country's percentage GD Ppc in terms of } \\
\text { G ermany's GD Ppc, each subtracted by logarithm of G ermany's percentage itself }\end{array}$ \\
\hline$<20$ empl. & Firm with less than 20 employees \\
\hline 20-199 empl. & Firm with 20 to 199 employees \\
\hline 200-1999 empl. & Firm with 200 to 1,999 employees \\
\hline$>2,000 \mathrm{empl}$ & Firm with more than 2,000 employees \\
\hline job tenure & Job tenure, in years \\
\hline Manufacturing & Economic sector: Manufacturing \\
\hline Construction & Economic sector: Construction \\
\hline Wholesale \& retail trade & Economic sector: Wholesale and retail trade \\
\hline Transportation \& storage & Economic sector: Transportation and storage \\
\hline Finance, insurance, real estate & Economic sector: Finance and insurance \& real estate \\
\hline high service & EG P-classification 2 (occupations according to social status) \\
\hline low service & EG P-classification 3 (occupations according to social status) \\
\hline rout. non-manual & EG P-classification 4 (occupations according to social status) \\
\hline rout. servies-sales & EG P-classification 5 (occupations according to social status) \\
\hline skilled manual & EG P-classification 6 (occupations according to social status) \\
\hline semi-/ unsk. manual & EG P-classification 7 (occupations according to social status) \\
\hline farm labour & EG P-classification 8 (occupations according to social status) \\
\hline urban & D ummy: $1=$ urban region, $0=$ rural region \\
\hline share of for. pop. & Share of foreign population at ferderal state level, 31.12. \\
\hline real gdp p.c. & $\begin{array}{l}\text { Real gross domestic product per capita at ferderal state level, annual average } \\
\text { (prices of 2010) }\end{array}$ \\
\hline unempl. rate & Unemployment rate at ferderal state level, annual average \\
\hline
\end{tabular}


Table A. 2: Number of observations by population group and years

\begin{tabular}{|c|c|c|c|c|c|c|c|c|c|}
\hline & \multicolumn{2}{|c|}{ Natives } & \multicolumn{2}{|c|}{ Nat. Immigrants } & \multicolumn{4}{|c|}{ Foreigners } & \multirow[b]{2}{*}{ Total } \\
\hline & $\begin{array}{c}\text { Native. Ger. } \\
\text { w/ o } \\
\text { migration } \\
\text { backgr. }\end{array}$ & $\begin{array}{l}\text { Native Ger. } \\
\text { with } \\
\text { migration } \\
\text { backgr. }\end{array}$ & $\begin{array}{l}\text { Ethnic } \\
\text { Germans } \\
\text { repatriates }\end{array}$ & $\begin{array}{l}\text { Naturalised } \\
\text { Immigrants } \\
\text { w/ o eth. } \\
\text { G ermans }\end{array}$ & $\begin{array}{l}\text { Citizens of } \\
\text { Turkey }\end{array}$ & $\begin{array}{c}\text { Citizens of } \\
\text { southern } \\
\text { European } \\
\text { countries }\end{array}$ & $\begin{array}{l}\text { Citizens of } \\
\text { former } \\
\text { Yugoslavia }\end{array}$ & $\begin{array}{l}\text { Remaining } \\
\text { Foreigners }\end{array}$ & \\
\hline 1994 & 1,449 & 86 & 60 & 55 & 192 & 207 & 110 & 17 & 2,176 \\
\hline 1995 & 1,534 & 89 & 118 & 55 & 187 & 203 & 108 & 34 & 2,328 \\
\hline 1996 & 1,464 & 97 & 117 & 54 & 155 & 179 & 88 & 28 & 2,182 \\
\hline 1997 & 1,502 & 108 & 124 & 66 & 159 & 184 & 86 & 37 & 2,266 \\
\hline 1998 & 1,721 & 106 & 121 & 66 & 158 & 180 & 73 & 34 & 2,459 \\
\hline 1999 & 1,613 & 110 & 118 & 60 & 138 & 162 & 61 & 22 & 2,284 \\
\hline 2000 & 3,208 & 157 & 186 & 115 & 189 & 198 & 77 & 76 & 4,206 \\
\hline 2001 & 2,763 & 159 & 165 & 109 & 165 & 167 & 61 & 61 & 3,650 \\
\hline 2002 & 2,947 & 176 & 149 & 119 & 151 & 140 & 56 & 68 & 3,806 \\
\hline 2003 & 2,665 & 161 & 139 & 99 & 128 & 126 & 52 & 55 & 3,425 \\
\hline 2004 & 2,590 & 163 & 141 & 108 & 118 & 120 & 51 & 48 & 3,339 \\
\hline 2005 & 2,339 & 172 & 125 & 90 & 102 & 109 & 39 & 41 & 3,017 \\
\hline 2006 & 2,346 & 186 & 125 & 84 & 92 & 87 & 29 & 35 & 2,984 \\
\hline 2007 & 2,359 & 191 & 124 & 84 & 91 & 85 & 37 & 32 & 3,003 \\
\hline 2008 & 2,108 & 188 & 113 & 80 & 83 & 76 & 28 & 26 & 2,702 \\
\hline 2009 & 2,237 & 207 & 100 & 99 & 70 & 76 & 29 & 37 & 2,855 \\
\hline 2010 & 3,088 & 313 & 205 & 177 & 112 & 99 & 46 & 86 & 4,126 \\
\hline 2011 & 3,268 & 369 & 230 & 159 & 99 & 88 & 48 & 97 & 4,358 \\
\hline 2012 & 3,060 & 380 & 232 & 154 & 90 & 80 & 52 & 111 & 4,159 \\
\hline 2013 & 2,937 & 444 & 435 & 237 & 169 & 183 & 128 & 299 & 4,832 \\
\hline 2014 & 2,574 & 384 & 356 & 197 & 131 & 159 & 110 & 233 & 4,144 \\
\hline 2015 & 2,393 & 337 & 339 & 187 & 107 & 185 & 117 & 441 & 4,106 \\
\hline Total & 52,165 & 4,583 & 3,822 & 2,454 & 2,886 & 3,093 & 1,486 & 1,918 & 72,407 \\
\hline$\%$ & 72.0 & 6.3 & 5.3 & 3.4 & 4.0 & 4.3 & 2.1 & 2.6 & 100.0 \\
\hline
\end{tabular}


Table A. 3: Means of personality (Big Five) by groups

\begin{tabular}{|c|c|c|c|c|c|c|c|c|}
\hline & $\begin{array}{l}\text { Native } \\
\text { Germans } \\
\text { without } \\
\text { mig.back }\end{array}$ & $\begin{array}{l}\text { Naturalised } \\
\text { immigrants }\end{array}$ & $\begin{array}{l}\text { Foreigners } \\
\text { b }\end{array}$ & $\begin{array}{l}\text { Naturalised } \\
\text { immigrants } \\
\text { w/o ethn. } \\
\text { Germans }\end{array}$ & $\begin{array}{c}\text { Ethnic } \\
\text { Germans } \\
\text { repatriates }\end{array}$ & $\begin{array}{c}\text { Citizens of } \\
\text { Turkey }\end{array}$ & $\begin{array}{c}\text { Cit. of } \\
\text { southern } \\
\text { European } \\
\text { countries }\end{array}$ & $\begin{array}{c}\text { Citizens of } \\
\text { former } \\
\text { Yugoslavia }\end{array}$ \\
\hline \multicolumn{9}{|c|}{ Personality (Big Five) } \\
\hline Openness & 0.625 & 0.629 & $0.597 * * *$ & 0.626 & 0.630 & $0.554^{* * *}$ & $0.590^{* * *}$ & 0.630 \\
\hline Conscientiousness & 0.834 & $0.852 * * *$ & $0.847 * * *$ & 0.837 & $0.862 * * *$ & 0.842 & $0.848 * *$ & $0.870 * * *$ \\
\hline Extraversion & 0.672 & $0.642 * * *$ & $0.685 * *$ & $0.650 * * *$ & $0.636 * * *$ & 0.679 & $0.699 * * *$ & 0.672 \\
\hline Agreeableness & 0.740 & $0.767 * * *$ & 0.740 & 0.737 & $0.786^{* * *}$ & $0.768 * * *$ & $0.762^{* * *}$ & 0.732 \\
\hline Neuroticism & 0.506 & $0.523^{* * *}$ & $0.529 * * *$ & $0.523^{*}$ & $0.524 * * *$ & 0.511 & $0.554 * * *$ & 0.519 \\
\hline no. of obs. & 20,072 & 1,657 & 1,366 & 656 & 1,101 & 481 & 437 & 176 \\
\hline
\end{tabular}


Table A. 4: Wage equation: estimation results for Native Germans

\begin{tabular}{|c|c|c|c|c|c|c|c|c|c|}
\hline decile & q10 & q20 & q30 & $\mathrm{q} 40$ & q50 & $\mathrm{q} 60$ & q70 & q80 & q90 \\
\hline labour market experience & $\begin{array}{l}0.031^{* * *} \\
(0.002)\end{array}$ & $\begin{array}{l}0.029 * * * \\
(0.002)\end{array}$ & $\begin{array}{l}0.026^{* * *} \\
(0.001)\end{array}$ & $\begin{array}{l}0.025^{* * *} \\
(0.001)\end{array}$ & $\begin{array}{l}0.027 * * * \\
(0.001)\end{array}$ & $\begin{array}{l}0.028^{* * *} \\
(0.001)\end{array}$ & $\begin{array}{l}0.029 * * * \\
(0.001)\end{array}$ & $\begin{array}{l}0.033 * * * \\
(0.002)\end{array}$ & $\begin{array}{l}0.036 * * * \\
(0.002)\end{array}$ \\
\hline labour market experience (sq.) & $\begin{array}{l}-0.001 * * * \\
(0.000)\end{array}$ & $\begin{array}{l}-0.001 * * * \\
(0.000)\end{array}$ & $\begin{array}{l}-0.000^{* * *} \\
(0.000)\end{array}$ & $\begin{array}{l}-0.000 * * * \\
(0.000)\end{array}$ & $\begin{array}{l}-0.000^{* * *} \\
(0.000)\end{array}$ & $\begin{array}{l}-0.001 * * * \\
(0.000)\end{array}$ & $\begin{array}{l}-0.001 * * * \\
(0.000)\end{array}$ & $\begin{array}{l}-0.001 * * * \\
(0.000)\end{array}$ & $\begin{array}{l}-0.001 * * * \\
(0.000)\end{array}$ \\
\hline cohabitation & $\begin{array}{l}0.066^{* * *} \\
(0.009)\end{array}$ & $\begin{array}{l}0.072^{* * *} \\
(0.007)\end{array}$ & $\begin{array}{l}0.071^{* * *} \\
(0.006)\end{array}$ & $\begin{array}{l}0.054^{* * *} \\
(0.005)\end{array}$ & $\begin{array}{l}0.053^{* * *} \\
(0.006)\end{array}$ & $\begin{array}{l}0.047^{* * *} \\
(0.006)\end{array}$ & $\begin{array}{l}0.050^{* * *} \\
(0.006)\end{array}$ & $\begin{array}{l}0.053^{* * *} \\
(0.007)\end{array}$ & $\begin{array}{l}0.057^{* * *} \\
(0.009)\end{array}$ \\
\hline \multicolumn{10}{|l|}{ education (Ref.: low-skilled) } \\
\hline medium-skilled & $\begin{array}{l}-0.061^{* *} \\
(0.024)\end{array}$ & $\begin{array}{l}-0.037^{* *} \\
(0.016)\end{array}$ & $\begin{array}{l}-0.014 \\
(0.013)\end{array}$ & $\begin{array}{l}0.004 \\
(0.012)\end{array}$ & $\begin{array}{l}0.011 \\
(0.011)\end{array}$ & $\begin{array}{l}0.028^{* * * *} \\
(0.011)\end{array}$ & $\begin{array}{l}0.039 * * * \\
(0.010)\end{array}$ & $\begin{array}{l}0.044 * * * \\
(0.011)\end{array}$ & $\begin{array}{l}0.067 * * * \\
(0.013)\end{array}$ \\
\hline high-skilled & $\begin{array}{l}0.022 \\
(0.028) \\
\end{array}$ & $\begin{array}{l}0.058^{* * *} \\
(0.019)\end{array}$ & $\begin{array}{l}0.095^{* * *} \\
(0.015)\end{array}$ & $\begin{array}{l}0.126^{* * *} \\
(0.014)\end{array}$ & $\begin{array}{l}0.155^{* * *} \\
(0.014)\end{array}$ & $\begin{array}{l}0.213^{* * *} \\
(0.014)\end{array}$ & $\begin{array}{l}0.265^{* * *} \\
(0.013)\end{array}$ & $\begin{array}{l}0.3635^{* *} \\
(0.013)\end{array}$ & $\begin{array}{l}0.439 * * * \\
(0.017)\end{array}$ \\
\hline German writing skills & $\begin{array}{l}0.181^{* * *} \\
(0.035)\end{array}$ & $\begin{array}{l}0.181^{* * *} \\
(0.023)\end{array}$ & $\begin{array}{l}0.156^{* * *} \\
(0.018)\end{array}$ & $\begin{array}{l}0.141^{* * *} \\
(0.015)\end{array}$ & $\begin{array}{l}0.145^{* * *} \\
(0.014)\end{array}$ & $\begin{array}{l}0.131^{* * * *} \\
(0.014)\end{array}$ & $\begin{array}{l}0.116 * * * \\
(0.013)\end{array}$ & $\begin{array}{l}0.116^{* * *} \\
(0.013)\end{array}$ & $\begin{array}{l}0.082 * * * \\
(0.017)\end{array}$ \\
\hline \multicolumn{10}{|l|}{ firm size (Ref.: less than 20 employees) } \\
\hline 20-199 empl. & $\begin{array}{l}0.185^{* * *} \\
(0.016)\end{array}$ & $\begin{array}{l}0.148^{* * *} \\
(0.011)\end{array}$ & $\begin{array}{l}0.107^{* * *} \\
(0.009)\end{array}$ & $\begin{array}{l}0.076^{* * *} \\
(0.008)\end{array}$ & $\begin{array}{l}0.052 * * * \\
(0.007)\end{array}$ & $\begin{array}{l}0.038^{* * *} \\
(0.007)\end{array}$ & $\begin{array}{l}0.030 * * * \\
(0.007)\end{array}$ & $\begin{array}{l}0.002 \\
(0.009)\end{array}$ & $\begin{array}{l}-0.038^{* * *} \\
(0.010)\end{array}$ \\
\hline 200-1999 empl. & $\begin{array}{l}0.257^{* * *} \\
(0.016)\end{array}$ & $\begin{array}{l}0.217^{* * *} \\
(0.011)\end{array}$ & $\begin{array}{l}0.177^{* * *} \\
(0.009)\end{array}$ & $\begin{array}{l}0.148 * * * \\
(0.008)\end{array}$ & $\begin{array}{l}0.117 * * * \\
(0.008)\end{array}$ & $\begin{array}{l}0.083 * * * \\
(0.008)\end{array}$ & $\begin{array}{l}0.063^{* * *} \\
(0.008)\end{array}$ & $\begin{array}{l}0.033^{* * *} \\
(0.009)\end{array}$ & $\begin{array}{l}-0.021^{*} \\
(0.011)\end{array}$ \\
\hline > 2,000 empl. & $\begin{array}{l}0.309 * * * \\
(0.015) \\
\end{array}$ & $\begin{array}{l}0.272 * * * \\
(0.011) \\
\end{array}$ & $\begin{array}{l}0.233^{* * *} \\
(0.009) \\
\end{array}$ & $\begin{array}{l}0.205^{* * *} \\
(0.008) \\
\end{array}$ & $\begin{array}{l}0.186^{* * *} \\
(0.008) \\
\end{array}$ & $\begin{array}{l}0.158^{* * *} \\
(0.008) \\
\end{array}$ & $\begin{array}{l}0.149 * * * \\
(0.008) \\
\end{array}$ & $\begin{array}{l}0.136 * * * \\
(0.009) \\
\end{array}$ & $\begin{array}{l}0.111^{* * *} \\
(0.012) \\
\end{array}$ \\
\hline \multicolumn{10}{|l|}{ economic sector (Ref.: other) } \\
\hline Manufacturing & $\begin{array}{l}0.060^{* * *} \\
(0.010)\end{array}$ & $\begin{array}{l}0.078^{* * *} \\
(0.007)\end{array}$ & $\begin{array}{l}0.075^{* * *} \\
(0.006)\end{array}$ & $\begin{array}{l}0.090^{* * *} \\
(0.006)\end{array}$ & $\begin{array}{l}0.112^{* * *} \\
(0.006)\end{array}$ & $\begin{array}{l}0.119 * * * \\
(0.006)\end{array}$ & $\begin{array}{l}0.136^{* * *} \\
(0.007)\end{array}$ & $\begin{array}{l}0.160^{* * *} \\
(0.008)\end{array}$ & $\begin{array}{l}0.164^{* * *} \\
(0.011)\end{array}$ \\
\hline Construction & $\begin{array}{l}0.149 * * * \\
(0.018)\end{array}$ & $\begin{array}{l}0.095^{* *} \\
(0.014)\end{array}$ & $\begin{array}{l}0.049^{* * *} \\
(0.011)\end{array}$ & $\begin{array}{l}0.042^{* * *} \\
(0.010)\end{array}$ & $\begin{array}{l}0.040^{* * *} \\
(0.009)\end{array}$ & $\begin{array}{l}0.032 * * * \\
(0.009)\end{array}$ & $\begin{array}{l}0.050^{* * *} \\
(0.009)\end{array}$ & $\begin{array}{l}0.050 * * * \\
(0.010)\end{array}$ & $\begin{array}{l}0.058^{* * *} \\
(0.012)\end{array}$ \\
\hline Wholesale and retail trade & $\begin{array}{l}-0.111^{* * *} \\
(0.021)\end{array}$ & $\begin{array}{l}-0.129^{* * *} \\
(0.014)\end{array}$ & $\begin{array}{l}-0.117^{* * *} \\
(0.011)\end{array}$ & $\begin{array}{l}-0.099 * * * \\
(0.009)\end{array}$ & $\begin{array}{l}-0.093^{* * *} \\
(0.009)\end{array}$ & $\begin{array}{l}-0.079 * * * \\
(0.009)\end{array}$ & $\begin{array}{l}-0.051^{* * *} \\
(0.009)\end{array}$ & $\begin{array}{l}-0.025^{* *} \\
(0.010)\end{array}$ & $\begin{array}{l}0.010 \\
(0.012)\end{array}$ \\
\hline Transportation and storage & $\begin{array}{l}-0.160^{* *} \\
(0.028)\end{array}$ & $\begin{array}{l}-0.094^{* * *} \\
(0.018)\end{array}$ & $\begin{array}{l}-0.088^{* * *} \\
(0.015)\end{array}$ & $\begin{array}{l}-0.061^{* * *} \\
(0.013)\end{array}$ & $\begin{array}{l}-0.044^{* * *} \\
(0.012)\end{array}$ & $\begin{array}{l}-0.019 \\
(0.012)\end{array}$ & $\begin{array}{l}-0.004 \\
(0.011)\end{array}$ & $\begin{array}{l}-0.006 \\
(0.012)\end{array}$ & $\begin{array}{l}-0.006 \\
(0.014)\end{array}$ \\
\hline Finance and insurance $\&$ real estate & $\begin{array}{l}0.125^{* * *} \\
(0.014) \\
\end{array}$ & $\begin{array}{l}0.131^{* * *} \\
(0.011)\end{array}$ & $\begin{array}{l}0.124^{* * *} \\
(0.010) \\
\end{array}$ & $\begin{array}{l}0.150^{* * *} \\
(0.010)\end{array}$ & $\begin{array}{l}0.182^{* * *} \\
(0.011)\end{array}$ & $\begin{array}{l}0.196 * * * \\
(0.012) \\
\end{array}$ & $\begin{array}{l}0.196 * * * \\
(0.014) \\
\end{array}$ & $\begin{array}{l}0.211^{* * *} \\
(0.019) \\
\end{array}$ & $\begin{array}{l}0.216^{* * *} \\
(0.025) \\
\end{array}$ \\
\hline \multicolumn{10}{|c|}{$\begin{array}{l}\text { occupational class (Ref.: semi-/unskilled } \\
\text { manual) }\end{array}$} \\
\hline high service & $\begin{array}{l}0.360 * * * \\
(0.020)\end{array}$ & $\begin{array}{l}0.327 * * * \\
(0.014)\end{array}$ & $\begin{array}{l}0.304^{* * *} \\
(0.011)\end{array}$ & $\begin{array}{l}0.313^{* * *} \\
(0.010)\end{array}$ & $\begin{array}{l}0.357 * * * \\
(0.010)\end{array}$ & $\begin{array}{l}0.376 * * * \\
(0.010)\end{array}$ & $\begin{array}{l}0.375 * * * \\
(0.010)\end{array}$ & $\begin{array}{l}0.365 * * * \\
(0.013)\end{array}$ & $\begin{array}{l}0.299 * * * \\
(0.015)\end{array}$ \\
\hline low service & $\begin{array}{l}0.354^{* * *} \\
(0.020)\end{array}$ & $\begin{array}{l}0.305^{* * *} \\
(0.013)\end{array}$ & $\begin{array}{l}0.268^{* * *} \\
(0.011)\end{array}$ & $\begin{array}{l}0.259^{* * *} \\
(0.010)\end{array}$ & $\begin{array}{l}0.265^{* * *} \\
(0.009)\end{array}$ & $\begin{array}{l}0.256^{* * *} \\
(0.009)\end{array}$ & $\begin{array}{l}0.209^{* * *} \\
(0.009)\end{array}$ & $\begin{array}{l}0.162^{* * *} \\
(0.011)\end{array}$ & $\begin{array}{l}0.104^{* * *} \\
(0.013)\end{array}$ \\
\hline rout. non-manual & $\begin{array}{l}0.047 \\
(0.039)\end{array}$ & $\begin{array}{l}0.102 * * * \\
(0.025)\end{array}$ & $\begin{array}{l}0.116^{* * *} \\
(0.019)\end{array}$ & $\begin{array}{l}0.133^{* * *} \\
(0.017)\end{array}$ & $\begin{array}{l}0.161^{* * *} \\
(0.016)\end{array}$ & $\begin{array}{l}0.164 * * * \\
(0.016)\end{array}$ & $\begin{array}{l}0.166^{* * *} \\
(0.016)\end{array}$ & $\begin{array}{l}0.172 * * * \\
(0.019)\end{array}$ & $\begin{array}{l}0.166^{* * *} \\
(0.025)\end{array}$ \\
\hline rout. services-sales & $\begin{array}{l}0.246^{* * *} \\
(0.023)\end{array}$ & $\begin{array}{l}0.186^{* * *} \\
(0.015)\end{array}$ & $\begin{array}{l}0.151^{* * *} \\
(0.012)\end{array}$ & $\begin{array}{l}0.133^{* * *} \\
(0.011)\end{array}$ & $\begin{array}{l}0.133^{* * *} \\
(0.010)\end{array}$ & $\begin{array}{l}0.129 * * * \\
(0.010)\end{array}$ & $\begin{array}{l}0.115^{* * *} \\
(0.010)\end{array}$ & $\begin{array}{l}0.096^{* * *} \\
(0.011)\end{array}$ & $\begin{array}{l}0.058^{* * *} \\
(0.013)\end{array}$ \\
\hline skilled manual & $\begin{array}{l}0.284 * * * \\
(0.018)\end{array}$ & $\begin{array}{l}0.172 * * * \\
(0.013)\end{array}$ & $\begin{array}{l}0.129^{* * *} \\
(0.010)\end{array}$ & $\begin{array}{l}0.099 * * * \\
(0.009)\end{array}$ & $\begin{array}{l}0.087 * * * \\
(0.008)\end{array}$ & $\begin{array}{l}0.066^{* * *} \\
(0.008)\end{array}$ & $\begin{array}{l}0.023 * * * \\
(0.007)\end{array}$ & $\begin{array}{l}-0.020^{* *} \\
(0.008)\end{array}$ & $\begin{array}{l}-0.045^{* * *} \\
(0.009)\end{array}$ \\
\hline farm labour & $\begin{array}{l}-0.028 \\
(0.065) \\
\end{array}$ & $\begin{array}{l}-0.011 \\
(0.042)\end{array}$ & $\begin{array}{l}-0.050 \\
(0.032)\end{array}$ & $\begin{array}{l}-0.052^{* *} \\
(0.024)\end{array}$ & $\begin{array}{l}-0.021 \\
(0.021)\end{array}$ & $\begin{array}{l}0.014 \\
(0.019)\end{array}$ & $\begin{array}{l}0.045^{* *} \\
(0.019)\end{array}$ & $\begin{array}{l}0.051^{* *} \\
(0.021)\end{array}$ & $\begin{array}{l}0.036^{* * * *} \\
(0.014)\end{array}$ \\
\hline \multicolumn{10}{|l|}{ regional characteristics } \\
\hline urban & $\begin{array}{l}0.040 * * * \\
(0.012)\end{array}$ & $\begin{array}{l}0.035^{* * *} \\
(0.008)\end{array}$ & $\begin{array}{l}0.037 * * * \\
(0.007)\end{array}$ & $\begin{array}{l}0.046^{* * *} \\
(0.007)\end{array}$ & $\begin{array}{l}0.049^{* * *} \\
(0.007)\end{array}$ & $\begin{array}{l}0.050 * * * \\
(0.007)\end{array}$ & $\begin{array}{l}0.037 * * * \\
(0.007)\end{array}$ & $\begin{array}{l}0.050 * * * \\
(0.008)\end{array}$ & $\begin{array}{l}0.053^{* * *} \\
(0.010)\end{array}$ \\
\hline share of for. pop. & $\begin{array}{l}-0.016 \\
(0.010)\end{array}$ & $\begin{array}{l}0.001 \\
(0.007)\end{array}$ & $\begin{array}{l}0.007 \\
(0.006)\end{array}$ & $\begin{array}{l}0.010^{*} \\
(0.006)\end{array}$ & $\begin{array}{l}0.013^{* *} \\
(0.006)\end{array}$ & $\begin{array}{l}0.011^{*} \\
(0.006)\end{array}$ & $\begin{array}{l}0.009 \\
(0.006)\end{array}$ & $\begin{array}{l}0.002 \\
(0.007)\end{array}$ & $\begin{array}{l}-0.005 \\
(0.009)\end{array}$ \\
\hline unempl. rate & $\begin{array}{l}0.015^{*} \\
(0.009)\end{array}$ & $\begin{array}{l}-0.001 \\
(0.006)\end{array}$ & $\begin{array}{l}-0.011^{* *} \\
(0.005)\end{array}$ & $\begin{array}{l}-0.007 \\
(0.005)\end{array}$ & $\begin{array}{l}-0.003 \\
(0.005)\end{array}$ & $\begin{array}{l}-0.001 \\
(0.005)\end{array}$ & $\begin{array}{l}0.001 \\
(0.005)\end{array}$ & $\begin{array}{l}0.009 \\
(0.006)\end{array}$ & $\begin{array}{l}0.011 \\
(0.008)\end{array}$ \\
\hline real GDP p.c. & $\begin{array}{l}-0.000 \\
(0.000)\end{array}$ & $\begin{array}{l}0.000 \\
(0.000)\end{array}$ & $\begin{array}{l}0.000 \\
(0.000)\end{array}$ & $\begin{array}{l}0.000 \\
(0.000)\end{array}$ & $\begin{array}{l}0.000 \\
(0.000)\end{array}$ & $\begin{array}{l}0.000 \\
(0.000)\end{array}$ & $\begin{array}{l}0.000 \\
(0.000)\end{array}$ & $\begin{array}{l}0.000 \\
(0.000)\end{array}$ & $\begin{array}{l}0.000 \\
(0.000)\end{array}$ \\
\hline constant & $\begin{array}{l}1.468 * * * \\
(0.261) \\
\end{array}$ & $\begin{array}{l}1.571^{* * *} \\
(0.192) \\
\end{array}$ & $\begin{array}{l}1.795^{* * *} \\
(0.163) \\
\end{array}$ & $\begin{array}{l}1.846 * * * \\
(0.150) \\
\end{array}$ & $\begin{array}{l}1.810^{* * *} \\
(0.152) \\
\end{array}$ & $\begin{array}{l}1.841^{* * *} \\
(0.155) \\
\end{array}$ & $\begin{array}{l}2.029 * * * \\
(0.160) \\
\end{array}$ & $\begin{array}{l}2.011^{* * *} \\
(0.186) \\
\end{array}$ & $\begin{array}{l}2.131^{* * *} \\
(0.243) \\
\end{array}$ \\
\hline no. of obs. & 52,053 & 52,053 & 52,053 & 52,053 & 52,053 & 52,053 & 52,053 & 52,053 & 52,053 \\
\hline adj. $\mathrm{R}^{2}$ & 0.14 & 0.21 & 0.25 & 0.27 & 0.30 & 0.30 & 0.28 & 0.24 & 0.16 \\
\hline
\end{tabular}


Table A. 5: Wage equation: estimation results for Naturalised Immigrants

\begin{tabular}{|c|c|c|c|c|c|c|c|c|c|}
\hline decile & q10 & q20 & q30 & $\mathrm{q} 40$ & q50 & q60 & q70 & q80 & q90 \\
\hline labour market experience & $\begin{array}{l}0.009 \\
(0.005)\end{array}$ & $\begin{array}{l}0.015^{* * *} \\
(0.005)\end{array}$ & $\begin{array}{l}0.018^{* * *} \\
(0.004)\end{array}$ & $\begin{array}{l}0.018^{* * *} \\
(0.003)\end{array}$ & $\begin{array}{l}0.019 * * * \\
(0.003)\end{array}$ & $\begin{array}{l}0.023^{* * *} \\
(0.003)\end{array}$ & $\begin{array}{l}0.024^{* * *} \\
(0.004)\end{array}$ & $\begin{array}{l}0.042^{* * *} \\
(0.005)\end{array}$ & $\begin{array}{l}0.046 * * * \\
(0.005)\end{array}$ \\
\hline labour market experience (sq.) & $\begin{array}{l}-0.000 \\
(0.000)\end{array}$ & $\begin{array}{l}-0.000^{* *} \\
(0.000)\end{array}$ & $\begin{array}{l}-0.000^{* * *} \\
(0.000)\end{array}$ & $\begin{array}{l}-0.000^{* * *} \\
(0.000)\end{array}$ & $\begin{array}{l}-0.000^{* * *} \\
(0.000)\end{array}$ & $\begin{array}{l}-0.000^{* * *} \\
(0.000)\end{array}$ & $\begin{array}{l}-0.000 * * * \\
(0.000)\end{array}$ & $\begin{array}{l}-0.001 * * * \\
(0.000)\end{array}$ & $\begin{array}{l}-0.001^{* * *} \\
(0.000)\end{array}$ \\
\hline cohabitation & $\begin{array}{l}0.119 * * * \\
(0.034) \\
\end{array}$ & $\begin{array}{l}0.094 * * * \\
(0.028) \\
\end{array}$ & $\begin{array}{l}0.043^{* *} \\
(0.021)\end{array}$ & $\begin{array}{l}0.047^{* *} \\
(0.018) \\
\end{array}$ & $\begin{array}{l}0.022 \\
(0.017) \\
\end{array}$ & $\begin{array}{l}0.034^{*} \\
(0.019) \\
\end{array}$ & $\begin{array}{l}0.043^{* *} \\
(0.020)\end{array}$ & $\begin{array}{l}0.059 * * \\
(0.027) \\
\end{array}$ & $\begin{array}{l}0.016 \\
(0.035) \\
\end{array}$ \\
\hline \multicolumn{10}{|l|}{ education (Ref.: low-skilled) } \\
\hline medium-skilled & $\begin{array}{l}0.0733^{* * *} \\
(0.026)\end{array}$ & $\begin{array}{l}0.030 \\
(0.022)\end{array}$ & $\begin{array}{l}0.061^{* * *} \\
(0.017)\end{array}$ & $\begin{array}{l}0.055^{* *} \\
(0.015)\end{array}$ & $\begin{array}{l}0.064 * * * \\
(0.015)\end{array}$ & $\begin{array}{l}0.084^{* * *} \\
(0.017)\end{array}$ & $\begin{array}{l}0.081^{* * *} \\
(0.018)\end{array}$ & $\begin{array}{l}0.121 * * * \\
(0.026)\end{array}$ & $\begin{array}{l}0.059^{* *} \\
(0.028)\end{array}$ \\
\hline high-skilled & $\begin{array}{l}0.109 * * * \\
(0.033) \\
\end{array}$ & $\begin{array}{l}0.058^{*} \\
(0.030)\end{array}$ & $\begin{array}{l}0.060^{* * *} \\
(0.022) \\
\end{array}$ & $\begin{array}{l}0.085^{* * * *} \\
(0.021) \\
\end{array}$ & $\begin{array}{l}0.109 * * * \\
(0.020) \\
\end{array}$ & $\begin{array}{l}0.130^{* * *} \\
(0.024) \\
\end{array}$ & $\begin{array}{l}0.159 * * * \\
(0.027) \\
\end{array}$ & $\begin{array}{l}0.2871^{* * *} \\
(0.039)\end{array}$ & $\begin{array}{l}0.386 * * * \\
(0.056) \\
\end{array}$ \\
\hline German writing skills & $\begin{array}{l}0.023^{*} \\
(0.011) \\
\end{array}$ & $\begin{array}{l}0.022 * \\
(0.010) \\
\end{array}$ & $\begin{array}{l}0.014 * \\
(0.007) \\
\end{array}$ & $\begin{array}{l}0.024 * * * \\
(0.006) \\
\end{array}$ & $\begin{array}{l}0.020^{* * *} \\
(0.006)\end{array}$ & $\begin{array}{l}0.033^{* * *} \\
(0.006) \\
\end{array}$ & $\begin{array}{l}0.037 * * * \\
(0.006) \\
\end{array}$ & $\begin{array}{l}0.046 * * * \\
(0.008) \\
\end{array}$ & $\begin{array}{l}0.034^{* * *} \\
(0.009)\end{array}$ \\
\hline \multicolumn{10}{|l|}{ firm size (Ref.: less than 20 employees) } \\
\hline 20-199 empl. & $\begin{array}{l}0.029 \\
(0.036)\end{array}$ & $\begin{array}{l}0.032 \\
(0.032)\end{array}$ & $\begin{array}{l}0.43^{*} \\
(0.024)\end{array}$ & $\begin{array}{l}0.059 * * * \\
(0.021)\end{array}$ & $\begin{array}{l}0.068^{* * *} \\
(0.018)\end{array}$ & $\begin{array}{l}0.053^{* * *} \\
(0.019)\end{array}$ & $\begin{array}{l}0.015 \\
(0.018)\end{array}$ & $\begin{array}{l}-0.000 \\
(0.025)\end{array}$ & $\begin{array}{l}-0.023 \\
(0.027)\end{array}$ \\
\hline 200-1999 empl. & $\begin{array}{l}0.101^{* * *} \\
(0.034)\end{array}$ & $\begin{array}{l}0.165^{* * *} \\
(0.030)\end{array}$ & $\begin{array}{l}0.165^{* * *} \\
(0.023)\end{array}$ & $\begin{array}{l}0.179 * * * \\
(0.020)\end{array}$ & $\begin{array}{l}0.182^{* * *} \\
(0.019)\end{array}$ & $\begin{array}{l}0.163^{* * *} \\
(0.021)\end{array}$ & $\begin{array}{l}0.117^{* * *} \\
(0.022)\end{array}$ & $\begin{array}{l}0.078^{* * *} \\
(0.030)\end{array}$ & $\begin{array}{l}-0.005 \\
(0.033)\end{array}$ \\
\hline > 2,000 empl. & $\begin{array}{l}0.086 * * \\
(0.039) \\
\end{array}$ & $\begin{array}{l}0.156^{* * *} \\
(0.032) \\
\end{array}$ & $\begin{array}{l}0.176^{* * *} \\
(0.025) \\
\end{array}$ & $\begin{array}{l}0.213^{* * *} \\
(0.022) \\
\end{array}$ & $\begin{array}{l}0.240 * * * \\
(0.021) \\
\end{array}$ & $\begin{array}{l}0.251^{* * *} \\
(0.023) \\
\end{array}$ & $\begin{array}{l}0.256^{* * *} \\
(0.024) \\
\end{array}$ & $\begin{array}{l}0.357^{* * *} \\
(0.035) \\
\end{array}$ & $\begin{array}{l}0.290^{* * *} \\
(0.046) \\
\end{array}$ \\
\hline \multicolumn{10}{|l|}{ economic sector (Ref.: other) } \\
\hline Manufacturing & $\begin{array}{l}0.141^{* * *} \\
(0.034)\end{array}$ & $\begin{array}{l}0.101^{* * *} \\
(0.028)\end{array}$ & $\begin{array}{l}0.064^{* * *} \\
(0.020)\end{array}$ & $\begin{array}{l}0.047^{* *} \\
(0.019)\end{array}$ & $\begin{array}{l}0.056^{* * *} \\
(0.018)\end{array}$ & $\begin{array}{l}0.075^{* * *} \\
(0.020)\end{array}$ & $\begin{array}{l}0.083^{* * *} \\
(0.021)\end{array}$ & $\begin{array}{l}0.144 * * * \\
(0.029)\end{array}$ & $\begin{array}{l}0.168^{* * *} \\
(0.037)\end{array}$ \\
\hline Construction & $\begin{array}{l}0.209^{* * *} \\
(0.047)\end{array}$ & $\begin{array}{l}0.158^{* * *} \\
(0.042)\end{array}$ & $\begin{array}{l}0.082^{* *} \\
(0.033)\end{array}$ & $\begin{array}{l}0.059^{* *} \\
(0.029)\end{array}$ & $\begin{array}{l}0.054^{* *} \\
(0.026)\end{array}$ & $\begin{array}{l}0.048^{*} \\
(0.028)\end{array}$ & $\begin{array}{l}0.015 \\
(0.026)\end{array}$ & $\begin{array}{l}0.056 \\
(0.036)\end{array}$ & $\begin{array}{l}0.040 \\
(0.038)\end{array}$ \\
\hline Wholesale and retail trade & $\begin{array}{l}-0.008 \\
(0.055)\end{array}$ & $\begin{array}{l}-0.086^{*} \\
(0.049)\end{array}$ & $\begin{array}{l}-0.072^{* * *} \\
(0.035)\end{array}$ & $\begin{array}{l}-0.055^{*} \\
(0.030)\end{array}$ & $\begin{array}{l}-0.072^{* * *} \\
(0.026)\end{array}$ & $\begin{array}{l}-0.064^{* *} \\
(0.030)\end{array}$ & $\begin{array}{l}-0.063^{* *} \\
(0.031)\end{array}$ & $\begin{array}{l}-0.056 \\
(0.044)\end{array}$ & $\begin{array}{l}-0.037 \\
(0.041)\end{array}$ \\
\hline Transportation and storage & $\begin{array}{l}-0.027 \\
(0.064)\end{array}$ & $\begin{array}{l}-0.090^{*} \\
(0.048)\end{array}$ & $\begin{array}{l}-0.103^{* * *} \\
(0.034)\end{array}$ & $\begin{array}{l}-0.123 * * * \\
(0.032)\end{array}$ & $\begin{array}{l}-0.090^{* * *} \\
(0.030)\end{array}$ & $\begin{array}{l}-0.058^{*} \\
(0.033)\end{array}$ & $\begin{array}{l}-0.055^{*} \\
(0.031)\end{array}$ & $\begin{array}{l}0.002 \\
(0.045)\end{array}$ & $\begin{array}{l}0.076 \\
(0.050)\end{array}$ \\
\hline Finance and insurance $\&$ real estate & $\begin{array}{l}0.074 \\
(0.053)\end{array}$ & $\begin{array}{l}0.116^{* * *} \\
(0.044) \\
\end{array}$ & $\begin{array}{l}0.101^{* * *} \\
(0.033)\end{array}$ & $\begin{array}{l}0.125^{* * *} \\
(0.031) \\
\end{array}$ & $\begin{array}{l}0.125^{* * *} \\
(0.033)\end{array}$ & $\begin{array}{l}0.166^{* * *} \\
(0.048)\end{array}$ & $\begin{array}{l}0.172^{* * *} \\
(0.063) \\
\end{array}$ & $\begin{array}{l}0.059 \\
(0.105)\end{array}$ & $\begin{array}{l}0.105 \\
(0.120)\end{array}$ \\
\hline \multicolumn{10}{|c|}{$\begin{array}{l}\text { occupational class (Ref.: semi-/unskilled } \\
\text { manual) }\end{array}$} \\
\hline high service & $\begin{array}{l}0.234 * * * \\
(0.039)\end{array}$ & $\begin{array}{l}0.316^{* * *} \\
(0.032)\end{array}$ & $\begin{array}{l}0.277 * * * \\
(0.025)\end{array}$ & $\begin{array}{l}0.307 * * * \\
(0.024)\end{array}$ & $\begin{array}{l}0.351^{* * *} \\
(0.023)\end{array}$ & $\begin{array}{l}0.440 * * * \\
(0.028)\end{array}$ & $\begin{array}{l}0.521 * * * \\
(0.032)\end{array}$ & $\begin{array}{l}0.729 * * * \\
(0.050)\end{array}$ & $\begin{array}{l}0.711 * * * \\
(0.068)\end{array}$ \\
\hline low service & $\begin{array}{l}0.247^{* * *} \\
(0.041)\end{array}$ & $\begin{array}{l}0.282^{* * *} \\
(0.036)\end{array}$ & $\begin{array}{l}0.243^{* * *} \\
(0.027)\end{array}$ & $\begin{array}{l}0.257 * * * \\
(0.025)\end{array}$ & $\begin{array}{l}0.291^{* * *} \\
(0.024)\end{array}$ & $\begin{array}{l}0.323^{* * *} \\
(0.028)\end{array}$ & $\begin{array}{l}0.332 * * * \\
(0.030)\end{array}$ & $\begin{array}{l}0.450 * * * \\
(0.044)\end{array}$ & $\begin{array}{l}0.301^{* * *} \\
(0.058)\end{array}$ \\
\hline rout. non-manual & $\begin{array}{l}0.085 \\
(0.077)\end{array}$ & $\begin{array}{l}0.080 \\
(0.070)\end{array}$ & $\begin{array}{l}0.085 \\
(0.054)\end{array}$ & $\begin{array}{l}0.120 * * * \\
(0.046)\end{array}$ & $\begin{array}{l}0.199 * * * \\
(0.042)\end{array}$ & $\begin{array}{l}0.251^{* * *} \\
(0.048)\end{array}$ & $\begin{array}{l}0.223 * * * \\
(0.049)\end{array}$ & $\begin{array}{l}0.295^{* * *} \\
(0.071)\end{array}$ & $\begin{array}{l}0.243^{* * *} \\
(0.069)\end{array}$ \\
\hline rout. services-sales & $\begin{array}{l}0.179 * * * \\
(0.042)\end{array}$ & $\begin{array}{l}0.191^{* * *} \\
(0.038)\end{array}$ & $\begin{array}{l}0.170^{* * *} \\
(0.031)\end{array}$ & $\begin{array}{l}0.158^{* * *} \\
(0.031)\end{array}$ & $\begin{array}{l}0.202^{* * *} \\
(0.031)\end{array}$ & $\begin{array}{l}0.192^{* * *} \\
(0.037)\end{array}$ & $\begin{array}{l}0.174^{* * *} \\
(0.042)\end{array}$ & $\begin{array}{l}0.175^{* *} \\
(0.052)\end{array}$ & $\begin{array}{l}0.057^{*} \\
(0.034)\end{array}$ \\
\hline skilled manual & $\begin{array}{l}0.157 * * * \\
(0.032)\end{array}$ & $\begin{array}{l}0.139 * * * \\
(0.027)\end{array}$ & $\begin{array}{l}0.104 * * * \\
(0.020)\end{array}$ & $\begin{array}{l}0.104 * * * \\
(0.018)\end{array}$ & $\begin{array}{l}0.099 * * * \\
(0.016)\end{array}$ & $\begin{array}{l}0.079 * * * \\
(0.017)\end{array}$ & $\begin{array}{l}0.069 * * * \\
(0.017)\end{array}$ & $\begin{array}{l}0.043^{*} \\
(0.023)\end{array}$ & $\begin{array}{l}0.025 \\
(0.024)\end{array}$ \\
\hline farm labour & $\begin{array}{l}-0.188 \\
(0.197) \\
\end{array}$ & $\begin{array}{l}-0.233^{*} \\
(0.137) \\
\end{array}$ & $\begin{array}{l}-0.139 \\
(0.094) \\
\end{array}$ & $\begin{array}{l}-0.061 \\
(0.080)\end{array}$ & $\begin{array}{l}-0.084 * \\
(0.043)\end{array}$ & $\begin{array}{l}-0.040 \\
(0.047) \\
\end{array}$ & $\begin{array}{l}-0.006 \\
(0.047)\end{array}$ & $\begin{array}{l}0.002 \\
(0.059)\end{array}$ & $\begin{array}{l}0.024 \\
(0.059) \\
\end{array}$ \\
\hline \multicolumn{10}{|l|}{ regional characteristics } \\
\hline urban & $\begin{array}{l}-0.074 * * * \\
(0.027)\end{array}$ & $\begin{array}{l}-0.017 \\
(0.027)\end{array}$ & $\begin{array}{l}0.064 * * * \\
(0.021)\end{array}$ & $\begin{array}{l}0.059 * * * \\
(0.018)\end{array}$ & $\begin{array}{l}0.049 * * * \\
(0.016)\end{array}$ & $\begin{array}{l}0.056^{* * *} \\
(0.017)\end{array}$ & $\begin{array}{l}0.027 \\
(0.018)\end{array}$ & $\begin{array}{l}0.016 \\
(0.025)\end{array}$ & $\begin{array}{l}0.067^{*} \\
(0.032)\end{array}$ \\
\hline share of for. pop. & $\begin{array}{l}-0.015 \\
(0.030)\end{array}$ & $\begin{array}{l}-0.008 \\
(0.027)\end{array}$ & $\begin{array}{l}-0.010 \\
(0.021)\end{array}$ & $\begin{array}{l}-0.019 \\
(0.021)\end{array}$ & $\begin{array}{l}-0.013 \\
(0.020)\end{array}$ & $\begin{array}{l}-0.005 \\
(0.024)\end{array}$ & $\begin{array}{l}-0.008 \\
(0.028)\end{array}$ & $\begin{array}{l}0.010 \\
(0.044)\end{array}$ & $\begin{array}{l}-0.049 \\
(0.044)\end{array}$ \\
\hline unempl. rate & $\begin{array}{l}-0.025 \\
(0.024)\end{array}$ & $\begin{array}{l}-0.005 \\
(0.022)\end{array}$ & $\begin{array}{l}0.013 \\
(0.016)\end{array}$ & $\begin{array}{l}-0.013 \\
(0.016)\end{array}$ & $\begin{array}{l}-0.010 \\
(0.014)\end{array}$ & $\begin{array}{l}-0.013 \\
(0.016)\end{array}$ & $\begin{array}{l}-0.005 \\
(0.017)\end{array}$ & $\begin{array}{l}-0.016 \\
(0.025)\end{array}$ & $\begin{array}{l}0.020 \\
(0.031)\end{array}$ \\
\hline real GDP p.c. & $\begin{array}{l}-0.000 \\
(0.000) \\
\end{array}$ & $\begin{array}{l}-0.000^{* *} \\
(0.000)\end{array}$ & $\begin{array}{l}-0.000 \\
(0.000) \\
\end{array}$ & $\begin{array}{l}-0.000 \\
(0.000) \\
\end{array}$ & $\begin{array}{l}-0.000 \\
(0.000) \\
\end{array}$ & $\begin{array}{l}-0.000 \\
(0.000) \\
\end{array}$ & $\begin{array}{l}0.000 \\
(0.000)\end{array}$ & $\begin{array}{l}0.000 \\
(0.000)\end{array}$ & $\begin{array}{l}0.000 \\
(0.000) \\
\end{array}$ \\
\hline constant & $\begin{array}{l}\text { 2.974*** } \\
(0.741) \\
\end{array}$ & $\begin{array}{l}3.128 * * * \\
(0.636) \\
\end{array}$ & $\begin{array}{l}2.460 * * * \\
(0.483) \\
\end{array}$ & $\begin{array}{l}2.797 * * * \\
(0.459) \\
\end{array}$ & $\begin{array}{l}2.743 * * * \\
(0.441) \\
\end{array}$ & $\begin{array}{l}2.745^{* * * *} \\
(0.525) \\
\end{array}$ & $\begin{array}{l}2.278 * * * \\
(0.547) \\
\end{array}$ & $\begin{array}{l}1.278^{*} \\
(0.734) \\
\end{array}$ & $\begin{array}{l}1.592 * \\
(0.853) \\
\end{array}$ \\
\hline no. of obs. & 6,255 & 6,255 & 6,255 & 6,255 & 6,255 & 6,255 & 6,255 & 6,255 & 6,255 \\
\hline adj. $\mathrm{R}^{2}$ & 0.10 & 0.15 & 0.20 & 0.25 & 0.30 & 0.32 & 0.35 & 0.35 & 0.29 \\
\hline
\end{tabular}


Table A. 6: Wage equation: estimation results for Foreigners

\begin{tabular}{|c|c|c|c|c|c|c|c|c|c|}
\hline decile & q10 & q20 & q30 & $\mathrm{q} 40$ & q50 & q60 & q70 & q80 & q90 \\
\hline labour market experience & $\begin{array}{l}0.033^{* * *} \\
(0.006)\end{array}$ & $\begin{array}{l}0.023^{* * *} \\
(0.004)\end{array}$ & $\begin{array}{l}0.020^{* * *} \\
(0.003)\end{array}$ & $\begin{array}{l}0.016 * * * \\
(0.002)\end{array}$ & $\begin{array}{l}0.016^{* * *} \\
(0.002)\end{array}$ & $\begin{array}{l}0.013 * * * \\
(0.002)\end{array}$ & $\begin{array}{l}0.015^{* * *} \\
(0.003)\end{array}$ & $\begin{array}{l}0.017^{* * *} \\
(0.004)\end{array}$ & $\begin{array}{l}0.021 * * * \\
(0.005)\end{array}$ \\
\hline labour market experience (sq.) & $\begin{array}{l}-0.001^{* * *} \\
(0.000)\end{array}$ & $\begin{array}{l}-0.000^{* * *} \\
(0.000)\end{array}$ & $\begin{array}{l}-0.000^{* * *} \\
(0.000)\end{array}$ & $\begin{array}{l}-0.000 * * * \\
(0.000)\end{array}$ & $\begin{array}{l}-0.000^{* * *} \\
(0.000)\end{array}$ & $\begin{array}{l}-0.000 * * \\
(0.000)\end{array}$ & $\begin{array}{l}-0.000 * * * \\
(0.000)\end{array}$ & $\begin{array}{l}-0.000 * * \\
(0.000)\end{array}$ & $\begin{array}{l}-0.000^{* * *} \\
(0.000)\end{array}$ \\
\hline cohabitation & $\begin{array}{l}0.027 \\
(0.031) \\
\end{array}$ & $\begin{array}{l}0.063 * * * \\
(0.022)\end{array}$ & $\begin{array}{l}0.055^{* * *} \\
(0.017)\end{array}$ & $\begin{array}{l}0.044 * * * \\
(0.014)\end{array}$ & $\begin{array}{l}0.045^{* * *} \\
(0.013)\end{array}$ & $\begin{array}{l}0.044 * * * \\
(0.014)\end{array}$ & $\begin{array}{l}0.018 \\
(0.015) \\
\end{array}$ & $\begin{array}{l}0.021 \\
(0.020) \\
\end{array}$ & $\begin{array}{l}0.115^{* * *} \\
(0.028)\end{array}$ \\
\hline \multicolumn{10}{|l|}{ education (Ref.: low-skilled) } \\
\hline medium-skilled & $\begin{array}{l}0.016 \\
(0.032)\end{array}$ & $\begin{array}{l}0.038^{*} \\
(0.021)\end{array}$ & $\begin{array}{l}0.038^{*} \\
(0.017)\end{array}$ & $\begin{array}{l}0.050^{* * *} \\
(0.015)\end{array}$ & $\begin{array}{l}0.045^{* * *} \\
(0.014)\end{array}$ & $\begin{array}{l}0.032 * * \\
(0.017)\end{array}$ & $\begin{array}{l}0.017 \\
(0.018)\end{array}$ & $\begin{array}{l}0.041^{*} \\
(0.023)\end{array}$ & $\begin{array}{l}-0.030 \\
(0.029)\end{array}$ \\
\hline high-skilled & $\begin{array}{l}0.056 \\
(0.040)\end{array}$ & $\begin{array}{l}0.089 * * * \\
(0.026)\end{array}$ & $\begin{array}{l}0.117^{* * *} \\
(0.020)\end{array}$ & $\begin{array}{l}0.105^{* * *} \\
(0.018)\end{array}$ & $\begin{array}{l}0.131^{* * *} \\
(0.018)\end{array}$ & $\begin{array}{l}0.141^{* * *} \\
(0.021)\end{array}$ & $\begin{array}{l}0.175^{* * *} \\
(0.026)\end{array}$ & $\begin{array}{l}0.264 * * * \\
(0.038)\end{array}$ & $\begin{array}{l}0.313^{* * *} \\
(0.060)\end{array}$ \\
\hline German writing skills & $\begin{array}{l}0.034 * * * \\
(0.008) \\
\end{array}$ & $\begin{array}{l}0.035^{* * *} \\
(0.006)\end{array}$ & $\begin{array}{l}0.036 * * * \\
(0.004)\end{array}$ & $\begin{array}{l}0.034 * * * \\
(0.004)\end{array}$ & $\begin{array}{l}0.034^{* * *} \\
(0.003)\end{array}$ & $\begin{array}{l}0.035 * * * \\
(0.004)\end{array}$ & $\begin{array}{l}0.031^{* * *} \\
(0.004)\end{array}$ & $\begin{array}{l}0.034 * * * \\
(0.006)\end{array}$ & $\begin{array}{l}0.035^{* * *} \\
(0.009) \\
\end{array}$ \\
\hline \multicolumn{10}{|l|}{ firm size (Ref.: less than 20 employees) } \\
\hline 20-199 empl. & $\begin{array}{l}0.212 * * * \\
(0.041)\end{array}$ & $\begin{array}{l}0.141^{* * *} \\
(0.027)\end{array}$ & $\begin{array}{l}0.115^{* * *} \\
(0.021)\end{array}$ & $\begin{array}{l}0.090^{* * *} \\
(0.017)\end{array}$ & $\begin{array}{l}0.097 * * * \\
(0.016)\end{array}$ & $\begin{array}{l}0.076^{* * *} \\
(0.016)\end{array}$ & $\begin{array}{l}0.074 * * * \\
(0.017)\end{array}$ & $\begin{array}{l}0.059 * * * \\
(0.021)\end{array}$ & $\begin{array}{l}-0.047^{*} \\
(0.026)\end{array}$ \\
\hline 200-1999 empl. & $\begin{array}{l}0.286 * * * \\
(0.040)\end{array}$ & $\begin{array}{l}0.237 * * * \\
(0.026)\end{array}$ & $\begin{array}{l}0.217^{* * * *} \\
(0.021)\end{array}$ & $\begin{array}{l}0.191^{* * *} \\
(0.018)\end{array}$ & $\begin{array}{l}0.196 * * * \\
(0.017)\end{array}$ & $\begin{array}{l}0.175^{* * *} \\
(0.017)\end{array}$ & $\begin{array}{l}0.171^{* * *} \\
(0.019)\end{array}$ & $\begin{array}{l}0.135^{* * * *} \\
(0.025)\end{array}$ & $\begin{array}{l}-0.027 \\
(0.033)\end{array}$ \\
\hline > 2,000 empl. & $\begin{array}{l}0.325 * * * \\
(0.040) \\
\end{array}$ & $\begin{array}{l}0.284 * * * \\
(0.026)\end{array}$ & $\begin{array}{l}0.268 * * * \\
(0.021) \\
\end{array}$ & $\begin{array}{l}0.252 * * * \\
(0.018) \\
\end{array}$ & $\begin{array}{l}0.271^{* * *} \\
(0.017) \\
\end{array}$ & $\begin{array}{l}0.271 * * * \\
(0.018)\end{array}$ & $\begin{array}{l}0.280 * * * \\
(0.021)\end{array}$ & $\begin{array}{l}0.274 * * * \\
(0.028) \\
\end{array}$ & $\begin{array}{l}0.119 * * * \\
(0.038) \\
\end{array}$ \\
\hline \multicolumn{10}{|l|}{ economic sector (Ref.: other) } \\
\hline Manufacturing & $\begin{array}{l}0.210^{* * *} \\
(0.033)\end{array}$ & $\begin{array}{l}0.150 * * * \\
(0.021)\end{array}$ & $\begin{array}{l}0.110 * * * \\
(0.016)\end{array}$ & $\begin{array}{l}0.087 * * * \\
(0.014)\end{array}$ & $\begin{array}{l}0.055^{* * *} \\
(0.013)\end{array}$ & $\begin{array}{l}0.053 * * * \\
(0.015)\end{array}$ & $\begin{array}{l}0.052 * * * \\
(0.018)\end{array}$ & $\begin{array}{l}0.036 \\
(0.024)\end{array}$ & $\begin{array}{l}0.088 * * \\
(0.035)\end{array}$ \\
\hline Construction & $\begin{array}{l}0.315 * * * \\
(0.044)\end{array}$ & $\begin{array}{l}0.217 * * * \\
(0.030)\end{array}$ & $\begin{array}{l}0.159 * * * \\
(0.024)\end{array}$ & $\begin{array}{l}0.100 * * * \\
(0.020)\end{array}$ & $\begin{array}{l}0.046 * * \\
(0.019)\end{array}$ & $\begin{array}{l}0.032 \\
(0.020)\end{array}$ & $\begin{array}{l}-0.000 \\
(0.022)\end{array}$ & $\begin{array}{l}-0.045 \\
(0.029)\end{array}$ & $\begin{array}{l}0.010 \\
(0.044)\end{array}$ \\
\hline Wholesale and retail trade & $\begin{array}{l}0.134 * * \\
(0.054)\end{array}$ & $\begin{array}{l}0.094 * * * \\
(0.036)\end{array}$ & $\begin{array}{l}0.083 * * * \\
(0.029)\end{array}$ & $\begin{array}{l}0.015 \\
(0.024)\end{array}$ & $\begin{array}{l}0.004 \\
(0.023)\end{array}$ & $\begin{array}{l}0.003 \\
(0.025)\end{array}$ & $\begin{array}{l}-0.037 \\
(0.027)\end{array}$ & $\begin{array}{l}-0.077 * \\
(0.034)\end{array}$ & $\begin{array}{l}-0.049 \\
(0.043)\end{array}$ \\
\hline Transportation and storage & $\begin{array}{l}0.093 \\
(0.066)\end{array}$ & $\begin{array}{l}-0.021 \\
(0.046)\end{array}$ & $\begin{array}{l}-0.062 * \\
(0.034)\end{array}$ & $\begin{array}{l}-0.047 * \\
(0.028)\end{array}$ & $\begin{array}{l}-0.050 * \\
(0.025)\end{array}$ & $\begin{array}{l}-0.060 * * \\
(0.027)\end{array}$ & $\begin{array}{l}-0.071^{* *} \\
(0.032)\end{array}$ & $\begin{array}{l}-0.094 * * \\
(0.042)\end{array}$ & $\begin{array}{l}-0.024 \\
(0.059)\end{array}$ \\
\hline Finance and insurance \& real estate & $\begin{array}{l}-0.020 \\
(0.119) \\
\end{array}$ & $\begin{array}{l}0.032 \\
(0.070) \\
\end{array}$ & $\begin{array}{l}0.037 \\
(0.051) \\
\end{array}$ & $\begin{array}{l}0.042 \\
(0.041) \\
\end{array}$ & $\begin{array}{l}0.067 * \\
(0.039) \\
\end{array}$ & $\begin{array}{l}-0.011 \\
(0.048) \\
\end{array}$ & $\begin{array}{l}-0.062 \\
(0.059) \\
\end{array}$ & $\begin{array}{l}-0.016 \\
(0.090) \\
\end{array}$ & $\begin{array}{l}0.223 \\
(0.172) \\
\end{array}$ \\
\hline \multicolumn{10}{|l|}{$\begin{array}{l}\text { occupational class (Ref.: semi- } \\
\text { /unskilled manual) }\end{array}$} \\
\hline high service & $\begin{array}{l}0.273 * * * \\
(0.044)\end{array}$ & $\begin{array}{l}0.286^{* * *} \\
(0.029)\end{array}$ & $\begin{array}{l}0.289^{* * *} \\
(0.023)\end{array}$ & $\begin{array}{l}0.279 * * * \\
(0.020)\end{array}$ & $\begin{array}{l}0.336^{* * *} \\
(0.019)\end{array}$ & $\begin{array}{l}0.387 * * * \\
(0.024)\end{array}$ & $\begin{array}{l}0.465^{* * *} \\
(0.031)\end{array}$ & $\begin{array}{l}0.654^{* * *} \\
(0.046)\end{array}$ & $\begin{array}{l}0.962 * * * \\
(0.081)\end{array}$ \\
\hline low service & $\begin{array}{l}0.309 * * * \\
(0.042)\end{array}$ & $\begin{array}{l}0.266 * * * \\
(0.029)\end{array}$ & $\begin{array}{l}0.246 * * * \\
(0.023)\end{array}$ & $\begin{array}{l}0.243^{* * *} \\
(0.020)\end{array}$ & $\begin{array}{l}0.276 * * * \\
(0.020)\end{array}$ & $\begin{array}{l}0.290 * * * \\
(0.024)\end{array}$ & $\begin{array}{l}0.340 * * * \\
(0.029)\end{array}$ & $\begin{array}{l}0.405 * * * \\
(0.041)\end{array}$ & $\begin{array}{l}0.454 * * * \\
(0.059)\end{array}$ \\
\hline rout. non-manual & $\begin{array}{l}0.204 * * * \\
(0.069)\end{array}$ & $\begin{array}{l}0.262^{* * *} \\
(0.047)\end{array}$ & $\begin{array}{l}0.289 * * * \\
(0.039)\end{array}$ & $\begin{array}{l}0.322 * * * \\
(0.032)\end{array}$ & $\begin{array}{l}0.355^{* * *} \\
(0.034)\end{array}$ & $\begin{array}{l}0.381^{* * *} \\
(0.038)\end{array}$ & $\begin{array}{l}0.426^{* * *} \\
(0.047)\end{array}$ & $\begin{array}{l}0.482^{* * *} \\
(0.068)\end{array}$ & $\begin{array}{l}0.561 * * * \\
(0.103)\end{array}$ \\
\hline rout. services-sales & $\begin{array}{l}0.064 \\
(0.056)\end{array}$ & $\begin{array}{l}0.064 * \\
(0.037)\end{array}$ & $\begin{array}{l}0.048^{*} \\
(0.027)\end{array}$ & $\begin{array}{l}0.069 * * * \\
(0.022)\end{array}$ & $\begin{array}{l}0.074 * * * \\
(0.021)\end{array}$ & $\begin{array}{l}0.061 * * * \\
(0.022)\end{array}$ & $\begin{array}{l}0.081^{* * *} \\
(0.024)\end{array}$ & $\begin{array}{l}0.076 * * \\
(0.032)\end{array}$ & $\begin{array}{l}-0.001 \\
(0.035)\end{array}$ \\
\hline skilled manual & $\begin{array}{l}0.136^{* * *} \\
(0.031)\end{array}$ & $\begin{array}{l}0.157 * * * \\
(0.021)\end{array}$ & $\begin{array}{l}0.160 * * * \\
(0.016)\end{array}$ & $\begin{array}{l}0.139 * * * \\
(0.013)\end{array}$ & $\begin{array}{l}0.157 * * * \\
(0.013)\end{array}$ & $\begin{array}{l}0.141^{* * *} \\
(0.013)\end{array}$ & $\begin{array}{l}0.108^{* * *} \\
(0.014)\end{array}$ & $\begin{array}{l}0.060 * * * \\
(0.017)\end{array}$ & $\begin{array}{l}0.039 * * \\
(0.019)\end{array}$ \\
\hline farm labour & $\begin{array}{l}-0.173 \\
(0.163) \\
\end{array}$ & $\begin{array}{l}-0.020 \\
(0.095) \\
\end{array}$ & $\begin{array}{l}-0.013 \\
(0.065) \\
\end{array}$ & $\begin{array}{l}0.023 \\
(0.053) \\
\end{array}$ & $\begin{array}{l}0.071 \\
(0.051) \\
\end{array}$ & $\begin{array}{l}0.118 * * \\
(0.055)\end{array}$ & $\begin{array}{l}0.092 * * \\
(0.040)\end{array}$ & $\begin{array}{l}0.131^{* *} \\
(0.059)\end{array}$ & $\begin{array}{l}0.085 \\
(0.064) \\
\end{array}$ \\
\hline \multicolumn{10}{|l|}{ regional characteristics } \\
\hline urban & $\begin{array}{l}-0.001 \\
(0.037)\end{array}$ & $\begin{array}{l}0.059 * \\
(0.026)\end{array}$ & $\begin{array}{l}0.072 * * * \\
(0.020)\end{array}$ & $\begin{array}{l}0.054^{* * *} \\
(0.017)\end{array}$ & $\begin{array}{l}0.043^{* * *} \\
(0.016)\end{array}$ & $\begin{array}{l}0.034^{*} \\
(0.018)\end{array}$ & $\begin{array}{l}0.036^{*} \\
(0.021)\end{array}$ & $\begin{array}{l}0.044^{*} \\
(0.026)\end{array}$ & $\begin{array}{l}0.040 \\
(0.041)\end{array}$ \\
\hline share of for. pop. & $\begin{array}{l}-0.046 \\
(0.028)\end{array}$ & $\begin{array}{l}0.008 \\
(0.019)\end{array}$ & $\begin{array}{l}0.007 \\
(0.016)\end{array}$ & $\begin{array}{l}0.014 \\
(0.014)\end{array}$ & $\begin{array}{l}0.011 \\
(0.013)\end{array}$ & $\begin{array}{l}0.024 \\
(0.015)\end{array}$ & $\begin{array}{l}0.026 \\
(0.017)\end{array}$ & $\begin{array}{l}0.024 \\
(0.023)\end{array}$ & $\begin{array}{l}0.028 \\
(0.036)\end{array}$ \\
\hline unempl. rate & $\begin{array}{l}-0.026 \\
(0.030)\end{array}$ & $\begin{array}{l}-0.013 \\
(0.018)\end{array}$ & $\begin{array}{l}-0.015 \\
(0.014)\end{array}$ & $\begin{array}{l}-0.013 \\
(0.011)\end{array}$ & $\begin{array}{l}-0.022 * * \\
(0.011)\end{array}$ & $\begin{array}{l}-0.008 \\
(0.012)\end{array}$ & $\begin{array}{l}-0.003 \\
(0.013)\end{array}$ & $\begin{array}{l}0.003 \\
(0.018)\end{array}$ & $\begin{array}{l}-0.057 * * \\
(0.024)\end{array}$ \\
\hline real GDP p.c. & $\begin{array}{l}0.000 \\
(0.000) \\
\end{array}$ & $\begin{array}{l}0.000 \\
(0.000)\end{array}$ & $\begin{array}{l}-0.000 \\
(0.000)\end{array}$ & $\begin{array}{l}-0.000 \\
(0.000) \\
\end{array}$ & $\begin{array}{l}0.000 \\
(0.000) \\
\end{array}$ & $\begin{array}{l}0.000 \\
(0.000)\end{array}$ & $\begin{array}{l}0.000^{*} \\
(0.000)\end{array}$ & $\begin{array}{l}0.000 * * \\
(0.000)\end{array}$ & $\begin{array}{l}0.000 \\
(0.000) \\
\end{array}$ \\
\hline constant & $\begin{array}{l}1.494 * * \\
(0.733) \\
\end{array}$ & $\begin{array}{l}1.337 * * * \\
(0.493) \\
\end{array}$ & $\begin{array}{l}2.013 * * * \\
(0.378) \\
\end{array}$ & $\begin{array}{l}2.226 * * * \\
(0.322) \\
\end{array}$ & $\begin{array}{l}2.146 * * * \\
(0.309) \\
\end{array}$ & $\begin{array}{l}1.551^{* * *} \\
(0.345) \\
\end{array}$ & $\begin{array}{l}1.293 * * * \\
(0.401) \\
\end{array}$ & $\begin{array}{l}1.023 * \\
(0.528) \\
\end{array}$ & $\begin{array}{l}2.481 * * * \\
(0.757) \\
\end{array}$ \\
\hline no. of obs. & 9,320 & 9,320 & 9,320 & 9,320 & 9,320 & 9,320 & 9,320 & 9,320 & 9,320 \\
\hline adj. $\mathrm{R}^{2}$ & 0.15 & 0.20 & 0.26 & 0.29 & 0.33 & 0.32 & 0.32 & 0.32 & 0.29 \\
\hline
\end{tabular}


Table A. 7: Decomposition of log real gross hourly wages at the mean. Reference group: Native Germans

\begin{tabular}{|c|c|c|c|c|c|c|c|}
\hline & Foreigners & $\begin{array}{l}\text { Naturalised } \\
\text { immigrants }\end{array}$ & $\begin{array}{l}\text { Naturalised } \\
\text { immigrants } \\
\text { w/o ethnic } \\
\text { Germans }\end{array}$ & $\begin{array}{c}\text { Ethnic } \\
\text { German } \\
\text { repatriates }\end{array}$ & $\begin{array}{c}\text { Citizens of } \\
\text { Turkey }\end{array}$ & $\begin{array}{l}\text { Citizens of } \\
\text { southern } \\
\text { European } \\
\text { countries }\end{array}$ & $\begin{array}{l}\text { Citizens of } \\
\text { former } \\
\text { Yugoslavia }\end{array}$ \\
\hline Mean wage: Germans & $2.78 * * *$ & $2.78 * * *$ & $2.78 * * *$ & $2.78 * * *$ & $2.78 * * *$ & $2.78 * * *$ & $2.78 * * *$ \\
\hline Mean wage: Migrants & $2.63^{* * *}$ & $2.65 * * *$ & $2.72^{* * *}$ & $2.59 * * *$ & $2.59 * * *$ & $2.68 * * *$ & $2.55^{* * *}$ \\
\hline Predicted difference & $0.148 * * *$ & $0.131^{* * *}$ & $0.062 * * *$ & $0.186^{* * *}$ & $0.195 * * *$ & $0.101^{* * *}$ & $0.231^{* * *}$ \\
\hline \multirow[t]{2}{*}{ Endowment effect } & $0.148 * * *$ & $0.107 * * *$ & 0.042 & $0.179 * * *$ & $0.200 * * *$ & $0.139 * * *$ & $0.269 * * *$ \\
\hline & $100 \%$ & $81 \%$ & $68 \%$ & $62 \%$ & $102 \%$ & $138 \%$ & $116 \%$ \\
\hline \multirow[t]{2}{*}{ Coefficient effect } & 0.000 & $0.025 * * *$ & $0.020^{*}$ & 0.007 & $-0.005 * * *$ & $-0.039 * * *$ & $-0.038 *$ \\
\hline & $0 \%$ & $19 \%$ & $32 \%$ & $38 \%$ & $-2 \%$ & $-38 \%$ & $-16 \%$ \\
\hline no. of obs. & 61,373 & 58,308 & 54,504 & 55,857 & 54,927 & 55,138 & 53.506 \\
\hline
\end{tabular}

Survey weights are integrated to counteract sample bias.

Table A. 8: UQR-decomposition of log real gross hourly wages. Reference group: Native Germans

\begin{tabular}{|c|c|c|c|c|c|c|c|c|c|}
\hline decile & 0.1 & 0.2 & 0.3 & 0.4 & 0.5 & 0.6 & 0.7 & 0.8 & 0.9 \\
\hline Mean wage: Germans & $2.32^{* * *}$ & $2.48^{* * *}$ & $2.60^{* * *}$ & $2.70^{* * *}$ & $2.78 * * *$ & $2.87 * * *$ & $2.97 * * *$ & $3.08^{* * *}$ & $3.26 * * *$ \\
\hline Mean wage: Migrants & $2.16^{* * *}$ & $2.35^{* * *}$ & $2.46 * * *$ & $2.54^{* * *}$ & $2.62 * * *$ & $2.70 * * *$ & $2.79 * * *$ & $2.91^{* * *}$ & $3.12 * * *$ \\
\hline \multirow[t]{2}{*}{ Endowment effect } & $0.098 * * *$ & $0.098 * * *$ & $0.150^{* * *}$ & $0.115^{* * *}$ & $0.132 * * *$ & $0.138 * * *$ & $0.150^{* * *}$ & $0.197 * * *$ & $0.205^{* * *}$ \\
\hline & $64 \%$ & $72 \%$ & $77 \%$ & $79 \%$ & $83 \%$ & $80 \%$ & $85 \%$ & $116 \%$ & $142 \%$ \\
\hline Coefficient effect & $0.056^{* *}$ & $0.039 * *$ & $0.033^{* *}$ & $0.031^{* * *}$ & $0.027 * *$ & $0.034^{* *}$ & $0.025 *$ & -0.027 & $-0.061 *$ \\
\hline Mean wage: Germans & $2.32 * * *$ & $2.48^{* * *}$ & $2.60^{* * *}$ & $2.70^{* * *}$ & $2.78^{* * *}$ & $2.87 * * *$ & $2.97 * * *$ & $3.08^{* * *}$ & $3.26 * * *$ \\
\hline Mean wage: Migrants & $2.22^{* * *}$ & $2.37^{* * *}$ & $2.47 * * *$ & $2.56^{* * *}$ & $2.63^{* * *}$ & $2.71^{* * *}$ & $2.80^{* * *}$ & $2.92^{* * *}$ & $3.12 * * *$ \\
\hline Predicted difference & $0.100 * * *$ & $0.110^{* * *}$ & $0.126 * * *$ & $0.135^{* * *}$ & $0.150^{* * *}$ & $0.161^{* * *}$ & $0.164^{* * *}$ & $0.160 * * *$ & $0.138 * * *$ \\
\hline \multirow[t]{2}{*}{ Endowment effect } & $0.044 * * *$ & $0.064^{* * *}$ & $0.063^{* * *}$ & $0.080^{* * *}$ & $0.089^{* * *}$ & $0.118^{* * *}$ & $0.135^{* * *}$ & $0.161^{* * *}$ & $0.120^{* * *}$ \\
\hline & $44 \%$ & $58 \%$ & $50 \%$ & $59 \%$ & $59 \%$ & $73 \%$ & $82 \%$ & $101 \%$ & $87 \%$ \\
\hline Coefficient effect & $0.057 * * *$ & $0.046^{* *}$ & $0.063^{* * *}$ & $0.056 * * *$ & $0.061^{* * *}$ & $0.043^{* * *}$ & $0.030^{*}$ & -0.001 & 0.018 \\
\hline
\end{tabular}


SUBGROUPS

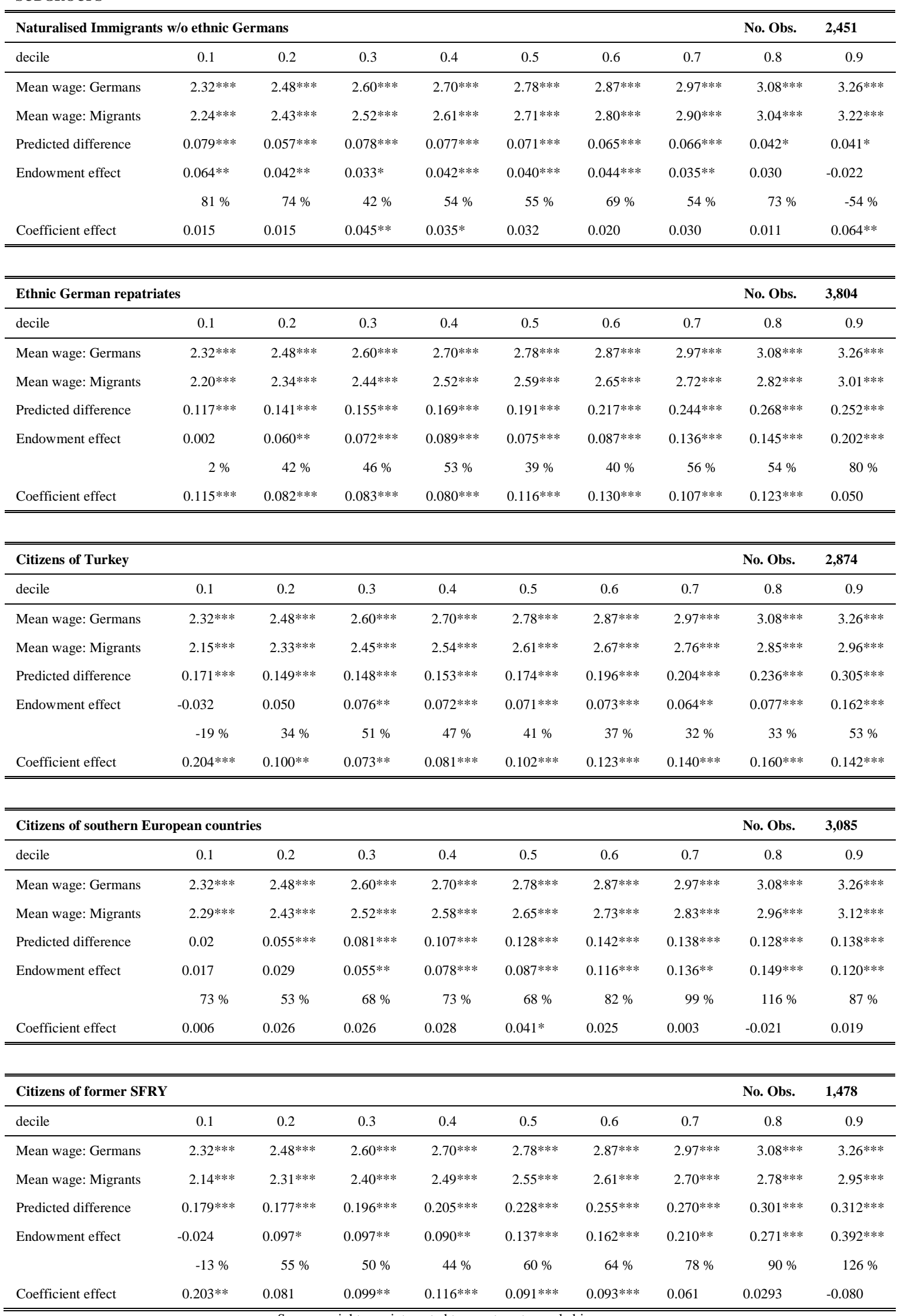


Table A. 9: Number of observations by wage deciles and immigrant groups - full sample

\begin{tabular}{|c|c|c|c|c|c|c|c|c|c|c|c|}
\hline decile & 0.1 & 0.2 & 0.3 & 0.4 & 0.5 & 0.6 & 0.7 & 0.8 & 0.9 & 1.0 & SUM \\
\hline Native Germans & 4,657 & 4,632 & 4,713 & 4,667 & 4,674 & 4,848 & 5,088 & 5,480 & 6,020 & 7,274 & 52,053 \\
\hline Nat. Immigrants & 991 & 964 & 883 & 765 & 591 & 580 & 422 & 381 & 366 & 312 & 6,255 \\
\hline Native Germans & 4,468 & 4,559 & 4,625 & 4,649 & 4,644 & 4,877 & 5,103 & 5,559 & 6,182 & 7,387 & 52,053 \\
\hline Foreigners & 1,607 & 1,408 & 1,325 & 1,074 & 872 & 790 & 664 & 572 & 512 & 521 & 9,345 \\
\hline Native Germans & 4,820 & 4,764 & 4,847 & 4,723 & 4,726 & 4,831 & 4,981 & 5,355 & 5,920 & 7,086 & 52,053 \\
\hline N.I. w/o ethn. Ger. & 333 & 291 & 279 & 521 & 219 & 244 & 181 & 203 & 226 & 224 & 2,451 \\
\hline Native Germans & 4,703 & 4,707 & 4,730 & 4,665 & 4,626 & 4,858 & 5,089 & 5,414 & 6,025 & 7,236 & 52,053 \\
\hline Ethn. Ger. repatriates & 684 & 691 & 587 & 506 & 378 & 329 & 229 & 172 & 137 & 81 & 3,804 \\
\hline Native Germans & 4,721 & 4,716 & 4,786 & 4,674 & 4,671 & 4,786 & 5,017 & 5,398 & 6,037 & 7,247 & 52,053 \\
\hline Citizens of Turkey & 493 & 464 & 460 & 366 & 279 & 274 & 236 & 151 & 94 & 57 & 2,874 \\
\hline Native Germans & 4,870 & 4,750 & 4,764 & 4,684 & 4,684 & 4,848 & 5,015 & 5,348 & 5,952 & 7,138 & 52,053 \\
\hline Cit. Southern Europe & 414 & 424 & 443 & 376 & 332 & 288 & 197 & 219 & 208 & 184 & 3,085 \\
\hline Native Germans & 4,782 & 4,710 & 4,811 & 4,733 & 4,657 & 4,581 & 5,015 & 5,393 & 5,962 & 7,139 & 52,053 \\
\hline Cit. Former Yugosl. & 285 & 252 & 253 & 187 & 142 & 114 & 70 & 80 & 60 & 35 & 1,478 \\
\hline
\end{tabular}


Table A. 10: Economic Distances (selected countries and years)

\begin{tabular}{|c|c|c|c|c|c|c|c|c|c|c|c|c|c|c|}
\hline & & 1956 & 1961 & 1966 & 1971 & 1976 & 1981 & 1986 & 1991 & 1996 & 2001 & 2006 & 2011 & 2016 \\
\hline 1 & Turkey & -0.6 & -0.6 & -0.7 & -0.7 & -0.6 & -0.7 & -0.7 & -0.7 & -0.7 & -0.7 & -0.6 & -0.6 & -0.5 \\
\hline 2 & Greece & -0.1 & -0.1 & -0.2 & -0.1 & -0.1 & -0.1 & -0.2 & -0.2 & -0.2 & -0.2 & -0.2 & -0.3 & -0.3 \\
\hline 3 & Italy & -0.1 & 0.0 & 0.0 & 0.0 & 0.0 & 0.0 & 0.0 & 0.0 & 0.0 & 0.0 & 0.0 & -0.1 & -0.1 \\
\hline 4 & Spain & -0.1 & -0.1 & -0.2 & -0.2 & -0.1 & -0.2 & -0.2 & -0.2 & -0.2 & -0.1 & -0.1 & -0.2 & -0.2 \\
\hline 5 & Portugal & -0.4 & -0.4 & -0.3 & -0.3 & -0.3 & -0.3 & -0.3 & -0.3 & -0.3 & -0.3 & -0.3 & -0.3 & -0.3 \\
\hline 6 & Yugoslavia (Former) & -0.7 & -0.7 & -0.6 & -0.6 & -0.6 & -0.5 & -0.6 & -0.7 & -1.0 & -0.9 & -0.8 & -0.8 & -0.8 \\
\hline 7 & Croatia & -0.6 & -0.6 & -0.5 & -0.5 & -0.5 & -0.4 & -0.5 & -0.6 & -0.6 & -0.6 & -0.5 & -0.5 & -0.5 \\
\hline 8 & Slovenia & -0.4 & -0.4 & -0.3 & -0.3 & -0.3 & -0.2 & -0.3 & -0.4 & -0.4 & -0.3 & -0.2 & -0.3 & -0.3 \\
\hline 9 & Bosnia and Herzegovina & -1.5 & -1.5 & -1.5 & -1.4 & -1.4 & -1.4 & -1.4 & -1.6 & -1.3 & -1.1 & -1.0 & -1.0 & -0.9 \\
\hline 10 & Serbia & -0.8 & -0.8 & -0.8 & -0.8 & -0.7 & -0.7 & -0.7 & -0.9 & -1.1 & -1.0 & -0.9 & -0.9 & -0.9 \\
\hline 11 & Montenegro & -0.8 & -0.7 & -0.7 & -0.7 & -0.7 & -0.6 & -0.7 & -0.8 & -0.9 & -0.9 & -0.8 & -0.8 & -0.8 \\
\hline 12 & Kosovo & -0.9 & -0.9 & -0.9 & -0.8 & -0.8 & -0.8 & -0.8 & -1.0 & -1.2 & -1.2 & -1.2 & -1.1 & -1.1 \\
\hline 13 & TFYR of Macedonia & -1.0 & -1.0 & -0.9 & -0.9 & -0.9 & -0.8 & -0.9 & -1.0 & -1.1 & -1.1 & -1.0 & -1.0 & -0.9 \\
\hline 14 & Poland & -0.6 & -0.6 & -0.6 & -0.6 & -0.6 & -0.7 & -0.6 & -0.8 & -0.7 & -0.7 & -0.6 & -0.5 & -0.5 \\
\hline 15 & Czech Republic & -0.4 & -0.4 & -0.4 & -0.4 & -0.3 & -0.3 & -0.3 & -0.4 & -0.4 & -0.4 & -0.3 & -0.3 & -0.3 \\
\hline 16 & Slovakia & -0.5 & -0.5 & -0.5 & -0.5 & -0.5 & -0.5 & -0.5 & -0.6 & -0.6 & -0.6 & -0.5 & -0.4 & -0.4 \\
\hline 17 & Hungary & -0.6 & -0.6 & -0.6 & -0.5 & -0.5 & -0.5 & -0.5 & -0.6 & -0.6 & -0.6 & -0.5 & -0.5 & -0.5 \\
\hline 18 & Romania & -1.2 & -1.1 & -1.0 & -0.9 & -0.7 & -0.7 & -0.7 & -0.9 & -0.8 & -0.9 & -0.7 & -0.7 & -0.7 \\
\hline 19 & Republic of Moldova & -1.3 & -1.2 & -1.2 & -1.2 & -1.2 & -1.1 & -1.1 & -1.2 & -1.6 & -1.6 & -1.5 & -1.5 & -1.4 \\
\hline 20 & Eastern Europe & -0.9 & -0.8 & -0.8 & -0.8 & -0.7 & -0.7 & -0.7 & -0.8 & -0.9 & -0.9 & -0.8 & -0.7 & -0.7 \\
\hline 21 & Estonia & -0.7 & -0.6 & -0.6 & -0.6 & -0.6 & -0.5 & -0.5 & -0.6 & -0.7 & -0.6 & -0.4 & -0.4 & -0.4 \\
\hline 22 & Latvia & -0.7 & -0.7 & -0.6 & -0.6 & -0.6 & -0.6 & -0.5 & -0.6 & -0.8 & -0.7 & -0.5 & -0.6 & -0.5 \\
\hline 23 & Lithuania & -0.7 & -0.7 & -0.6 & -0.6 & -0.6 & -0.6 & -0.5 & -0.6 & -0.8 & -0.7 & -0.6 & -0.5 & -0.5 \\
\hline 24 & Russian Federation & -0.7 & -0.7 & -0.6 & -0.6 & -0.6 & -0.6 & -0.5 & -0.6 & -0.8 & -0.8 & -0.6 & -0.6 & -0.6 \\
\hline 25 & Kazakhstan & -0.9 & -0.8 & -0.8 & -0.8 & -0.8 & -0.7 & -0.7 & -0.8 & -1.0 & -0.9 & -0.7 & -0.7 & -0.6 \\
\hline 26 & Ukraine & -1.0 & -0.9 & -0.9 & -0.9 & -0.9 & -0.8 & -0.8 & -0.9 & -1.3 & -1.3 & -1.1 & -1.1 & -1.2 \\
\hline 27 & Belarus & -1.2 & -1.1 & -1.1 & -1.1 & -1.1 & -1.0 & -1.0 & -1.0 & -1.2 & -1.1 & -0.9 & -0.8 & -0.9 \\
\hline 28 & Kyrgyzstan & -1.7 & -1.7 & -1.6 & -1.6 & -1.6 & -1.6 & -1.5 & -1.5 & -1.8 & -1.8 & -1.7 & -1.7 & -1.6 \\
\hline 29 & Uzbekistan & -1.7 & -1.7 & -1.6 & -1.6 & -1.6 & -1.6 & -1.5 & -1.5 & -1.7 & -1.7 & -1.6 & -1.5 & -1.4 \\
\hline 30 & Turkmenistan & -1.1 & -1.1 & -1.0 & -1.0 & -1.0 & -1.0 & -0.9 & -1.0 & -1.2 & -1.2 & -1.1 & -0.9 & -0.8 \\
\hline 31 & Tajikistan & -1.6 & -1.5 & -1.5 & -1.5 & -1.5 & -1.4 & -1.4 & -1.5 & -2.0 & -1.9 & -1.8 & -1.8 & -1.7 \\
\hline 32 & Armenia & -1.4 & -1.4 & -1.3 & -1.3 & -1.3 & -1.3 & -1.2 & -1.3 & -1.5 & -1.4 & -1.1 & -1.1 & -1.0 \\
\hline 33 & Azerbaijan & -1.2 & -1.1 & -1.1 & -1.1 & -1.1 & -1.0 & -1.0 & -1.0 & -1.5 & -1.3 & -1.0 & -0.9 & -0.9 \\
\hline 34 & G eorgia & -1.2 & -1.1 & -1.1 & -1.1 & -1.1 & -1.0 & -1.0 & -1.1 & -1.5 & -1.4 & -1.3 & -1.2 & -1.1 \\
\hline 35 & Netherlands & 0.1 & 0.1 & 0.1 & 0.1 & 0.1 & 0.1 & 0.0 & 0.0 & 0.1 & 0.1 & 0.1 & 0.1 & 0.1 \\
\hline 36 & Belgium & 0.0 & 0.0 & 0.0 & 0.0 & 0.0 & 0.0 & 0.0 & 0.0 & 0.0 & 0.0 & 0.0 & 0.0 & 0.0 \\
\hline 37 & Luxembourg & 0.3 & 0.3 & 0.2 & 0.2 & 0.2 & 0.2 & 0.2 & 0.3 & 0.3 & 0.4 & 0.4 & 0.4 & 0.4 \\
\hline 38 & France & 0.0 & 0.0 & 0.0 & 0.0 & 0.0 & 0.0 & 0.0 & 0.0 & 0.0 & 0.0 & 0.0 & 0.0 & 0.0 \\
\hline 39 & United Kingdom & 0.0 & 0.0 & 0.0 & 0.0 & -0.1 & -0.1 & -0.1 & -0.1 & 0.0 & 0.0 & 0.0 & -0.1 & 0.0 \\
\hline 40 & Austria & 0.0 & 0.0 & 0.0 & 0.0 & 0.0 & 0.0 & 0.0 & 0.0 & 0.0 & 0.0 & 0.0 & 0.0 & 0.0 \\
\hline 41 & Switzerland & 0.5 & 0.5 & 0.4 & 0.4 & 0.3 & 0.3 & 0.3 & 0.3 & 0.2 & 0.2 & 0.3 & 0.2 & 0.2 \\
\hline 42 & D enmark & 0.2 & 0.2 & 0.2 & 0.2 & 0.2 & 0.1 & 0.2 & 0.1 & 0.2 & 0.2 & 0.2 & 0.1 & 0.1 \\
\hline 43 & Sweden & 0.2 & 0.2 & 0.1 & 0.1 & 0.1 & 0.1 & 0.1 & 0.0 & 0.0 & 0.1 & 0.1 & 0.1 & 0.1 \\
\hline 44 & Finland & -0.1 & 0.0 & 0.0 & 0.0 & 0.0 & 0.0 & 0.0 & 0.0 & 0.0 & 0.0 & 0.1 & 0.0 & 0.0 \\
\hline 45 & Norway & 0.1 & 0.2 & 0.2 & 0.2 & 0.3 & 0.3 & 0.3 & 0.3 & 0.3 & 0.3 & 0.3 & 0.3 & 0.3 \\
\hline 46 & Afghanistan & -1.2 & -1.2 & -1.3 & -1.3 & -1.4 & -1.5 & -1.4 & -1.7 & -2.0 & -2.0 & -2.0 & -1.9 & -1.9 \\
\hline 47 & Iraq & -0.9 & -0.9 & -0.9 & -0.9 & -0.8 & -0.8 & -0.9 & -1.5 & -1.2 & -1.0 & -1.1 & -1.0 & -0.9 \\
\hline 48 & Syrian Arab Republic & -1.3 & -1.3 & -1.2 & -1.2 & -1.1 & -1.1 & -1.2 & -1.3 & -1.2 & -1.2 & -1.2 & -1.2 & -1.4 \\
\hline
\end{tabular}

Source: Own calculations based on United Nations Statistics Division (UNSD) (2017). 


\section{B. FIGURES}

Figure B. 1: Median log hourly wage by immigrant groups

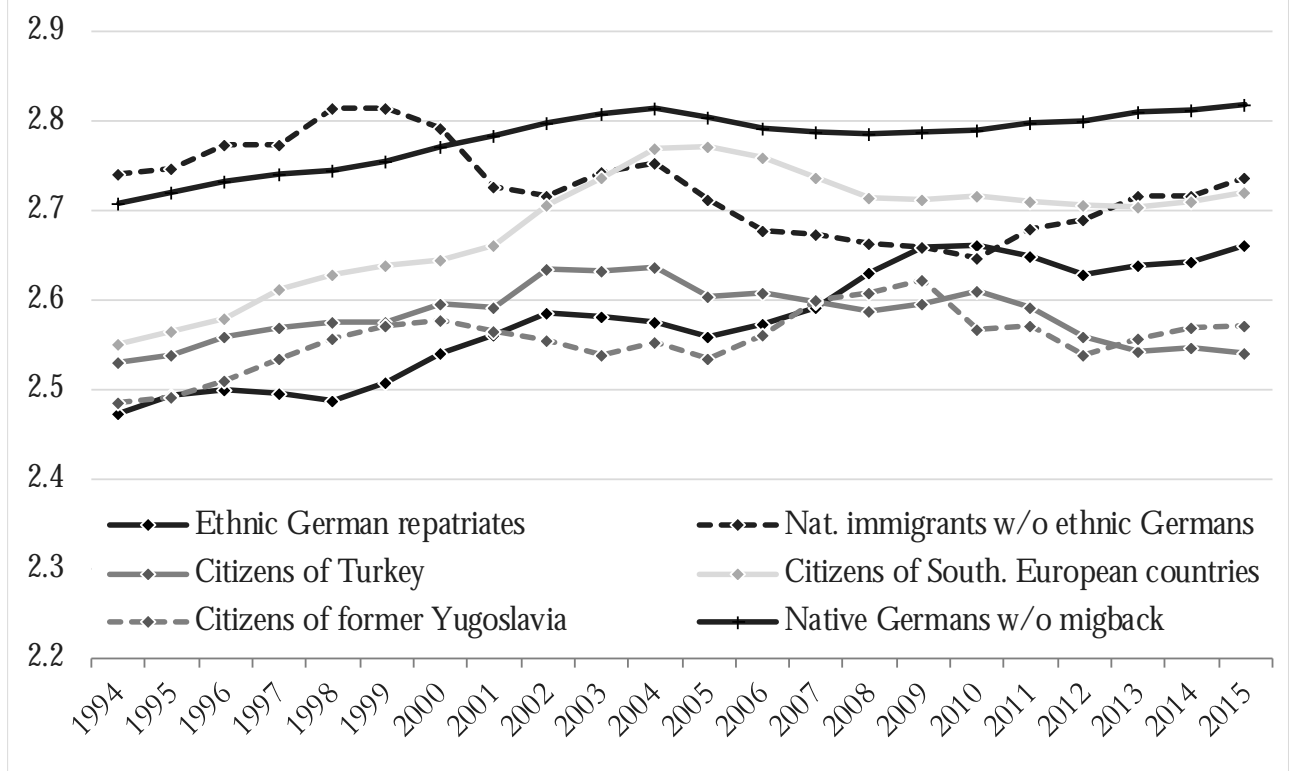

Source: DIW (2017), SOEP 1984-2015. Survey weights are integrated to counteract sample bias. Mean wages are smoothed with adjacent years.

Figure B. 2: Blinder-Oaxaca wage decomposition for UQR - segmentation of the endowment effect

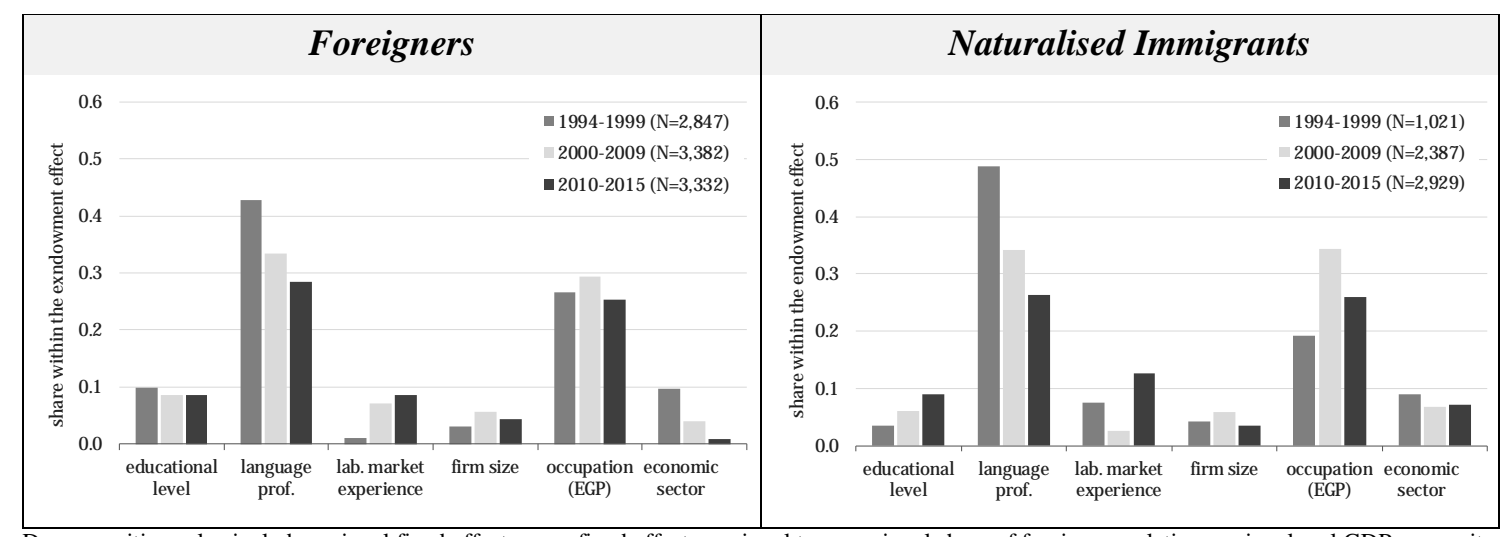

Decompositions also include regional fixed effects, year fixed effects, regional type, regional share of foreign population, regional real GDP per capita, and regional unemployment rate. 
Figure B. 3: Blinder-Oaxaca wage decomposition for UQR (1994-2015) - full-time \& part-time

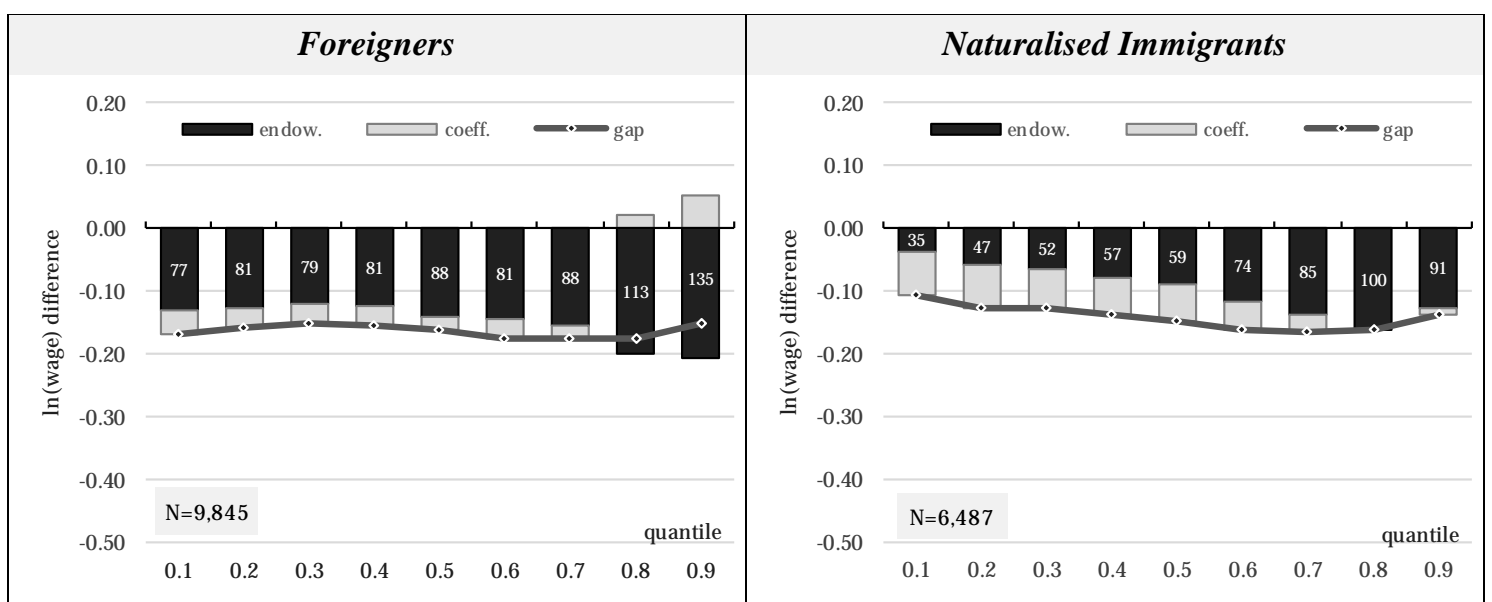

Survey weights are integrated to counteract sample bias. Covariates considered in the estimation are labour market experience, labour market experience squared, marital status, three skill levels, dummy variables for firm size, dummy variables for occupational class, dummy variables for industry, regional fixed effects, year fixed effects, regional type, regional share of foreign population, regional real GDP per capita, and regional unemployment rate. Source: DIW (2017), SOEP 1984-2015. Own calculations. 
Figure B. 4: Blinder-Oaxaca wage decomposition for UQR - Age cohorts of Foreigners

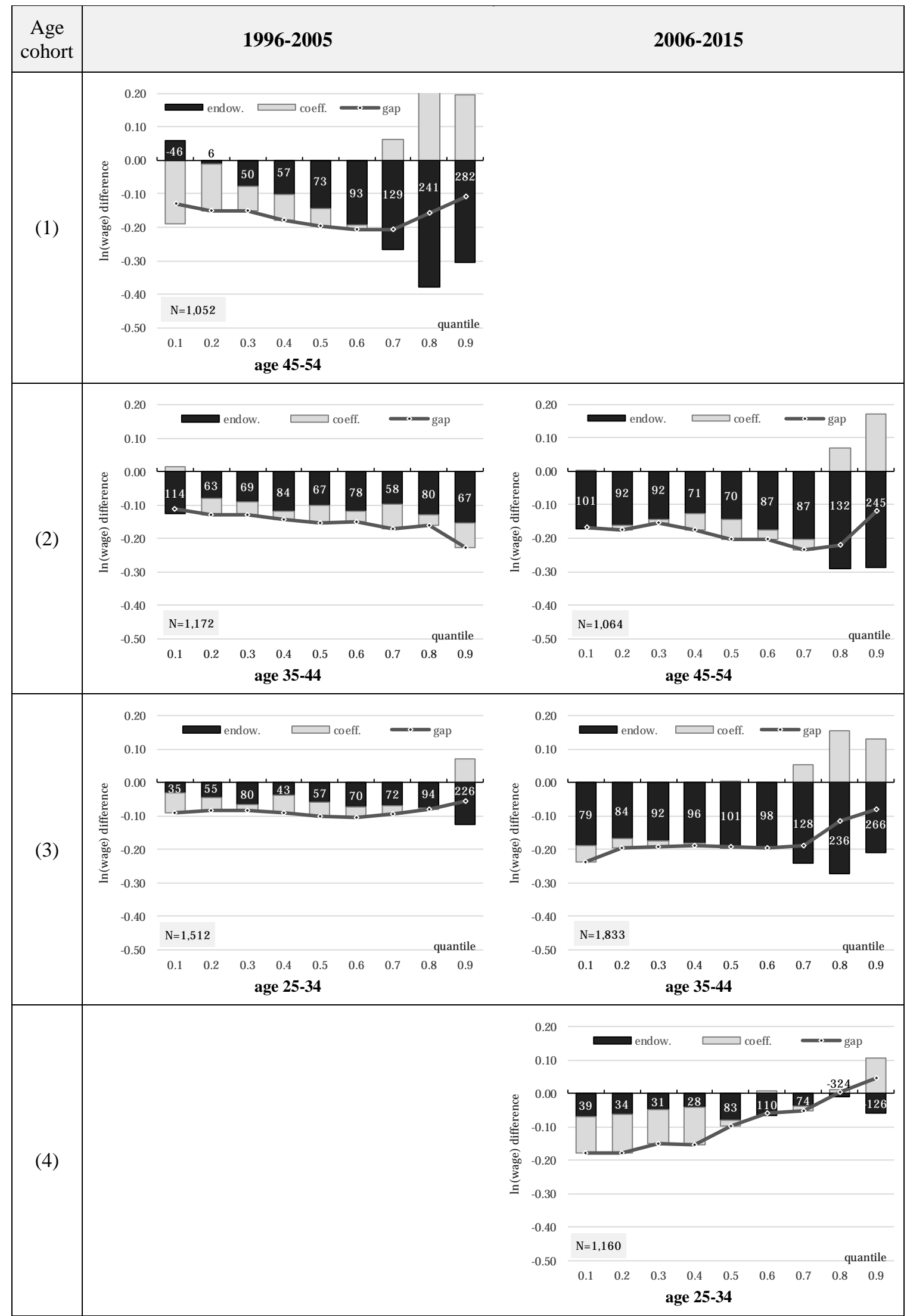

Survey weights are integrated to counteract sample bias. Covariates considered in the estimation are labour market experience, labour market experience squared, marital status, three skill levels, German writing skills, dummy variables for firm size, dummy variables for occupational class, dummy variables for industry, regional fixed effects, year fixed effects, regional type, regional share of foreign population, regional real GDP per capita, and regional unemployment rate. We exclude Foreigners who immigrated in the later course. Source: DIW (2017), SOEP 1984-2015. Own calculations. 
Figure B. 5: Blinder-Oaxaca wage decomposition for UQR - Age cohorts of Naturalised Immigrants

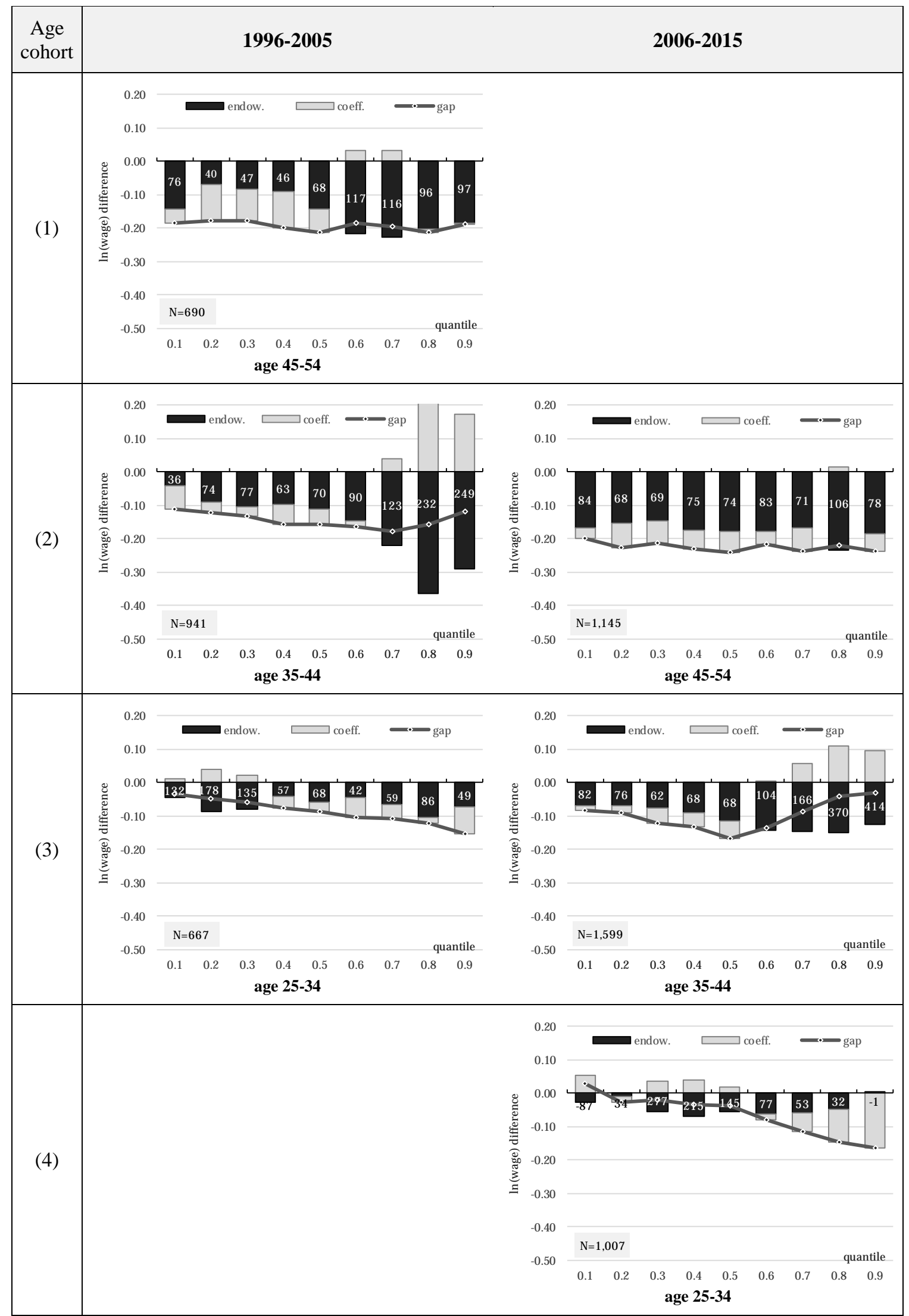

Survey weights are integrated to counteract sample bias. Covariates considered in the estimation are labour market experience, labour market experience squared, marital status, three skill levels, German writing skills, dummy variables for firm size, dummy variables for occupational class, dummy variables for industry, regional fixed effects, year fixed effects, regional type, regional share of foreign population, regional real GDP per capita, and regional unemployment rate. We exclude Foreigners who immigrated in the later course. Source: DIW (2017), SOEP 1984-2015. Own calculations. 


\section{GERMANY's HISTORY AS AN IMMIGRATION COUNTRY}

Germany has experienced large waves of immigration in the recent past. Each of these immigration waves were based on different migration motives and altogether, they brought a great variety of cultures from different regions of origin to Germany. We distinguish between six immigration waves since the Second World War.

The first movement took place in the last months of the war as well as in the post-war period and was characterised by war refugees and displaced persons from Eastern Europe towards Germany. Around 12.5 million citizens from Eastern provinces of the German Reich (Reichsdeutsche) and ethnic Germans living in Eastern and South-Eastern Europe (Volksdeutsche) succeeded escaping to Germany's "heartland”. A large part of another 10-12 million displaced persons residing in the Western zones at the end of 1945 were able to return to their home country until 1946 (Federal Agency for Civic Education, 2005).

The second movement was economically driven. Starting in the mid-1950s, West Germany (Federal Republic of Germany, FRG) experienced a strong economic boom associated with a shortage of low-skilled labour. The German Federal Government consequently initiated an immigration policy targeting the recruitment of temporary workers from Turkey, southern European and northern African countries (Anwerbeabkommen).

Figure C. 1: Foreigners and naturalised immigrants in Germany (1988 to 2015)

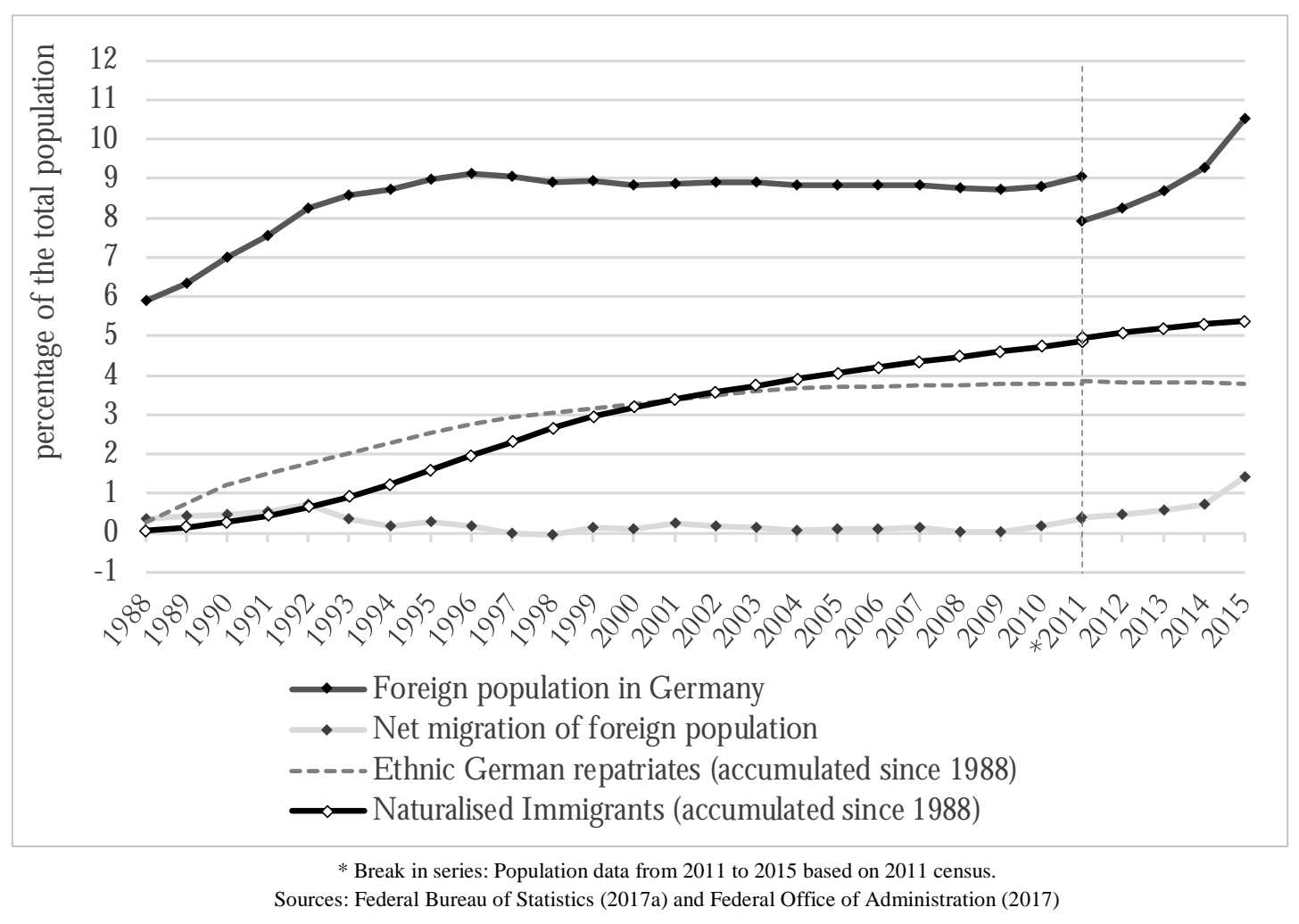


Due to an economic slowdown at the end of the 1960s and the economic crisis in the early 1970s, Germany’s government imposed a recruitment ban in $1973 .{ }^{1}$ At this time, around 2.5 million guest-workers were working in Germany ( $4 \%$ of the population). Integration measures have de facto not taken place for guest-workers. The succeeding family reunification led to a reverse population movement and compensated emigration of guest-workers. This third movement of post-war immigration was characterised by the emigration of men and the immigration of low-skilled women and children. As a result, the labour force participation of the foreign population diminished (Federal Agency for Civic Education, 2012). ${ }^{2}$

At the time of downfall of the Iron Curtain in 1989/1990, around 7 percent (5m) of the population living in West Germany (FRG) were people with foreign citizenship, while only 1 percent $(0.2 \mathrm{~m})$ were registered in the German Democratic Republic (GDR). In the subsequent years, the share of foreigners in the reunited Germany increased immediately due to immigration from (South)Eastern Europe and Central Asia (forth movement). Figure C. 1 shows immigration movements since the easing of travel restriction in $1988 .{ }^{3}$ At the beginning of the 1990s, immigration was even stronger than at time of the highest influx of guest-workers. ${ }^{4}$ Refugees from the first phase of Yugoslav Wars (1991-1995) caused an additional unexpected inflow of foreigners to Germany. ${ }^{5}$ Until 1996, the number of foreigner rose by about 3 million persons since 1988/1989 so that the share of foreign population reached 9 percent $(7.5 \mathrm{~m})$.

After the period of enormous immigration movement, the net migration of foreigners to Germany between 1997 and 2010 was close to zero (immigration equals emigration). ${ }^{6}$ Caused by the free movement law for citizens of the Eastern European EU member states since 2007 (fifth movement) and especially due a large quantity of refugees from war zones in the Middle East and African countries since 2014 (sixth movement), a notably inflow of foreigners again happens since $2011 .^{7}$ In this context, the share of resident foreigners in Germany rose to 10.5 percent (8.7m) in 2015 (Eurostat, 2018a; Federal Bureau of Statistics, 2017b). ${ }^{8}$

\footnotetext{
${ }^{1}$ After the economic boom of the 1950s, the average annual GDP growth rate in West Germany fell progressively from $8.2 \%$ to $4.4 \%$ (1960s), $3.1 \%$ (1970s) and then to $2.0 \%$ (1980s). In the early 70s and early 80s, there were even partially negative GDP growth rates (Federal Bureau of Statistics, 2017b).

${ }^{2}$ See Schmidt (1997) for further detailed information.

${ }^{3}$ The unrestricted freedom of travel was introduced in Hungary on January $1^{\text {st }}, 1988$ that enticed the citizens of the GDR to escape across the Hungarian-Austrian border (German Bundestag, 2014).

${ }^{4}$ The net-migration reached its peak in 1993 with +600.000 persons ( $0.7 \%$ of the population). In 1969 and 1970, the net-migration was +540.000 persons each (Federal Bureau of Statistics, 2017b).

${ }^{5}$ First phase of Yugoslav Wars: Ten-Day War in Slovenia (1991), Croatian War of Independence (1991-1995), Bosnian War (1992-1995). Second phase of Yugoslav Wars: Kosovo War (1998-1999), insurgency in the Republic of Macedonia (2001).

${ }^{6}$ Three possible reasons for lower net migration between 1997 and 2010 are conceivable: (1) a new German law of asylum in 1993 with e.g. the implementation of "Drittstaatenregelung" that reduced the number of countries of origin those citizens have a right of asylum for Germany. (2) The Dublin Regulation (1997) states that the responsible member state will be the state through which the asylum seeker first entered the EU. (3) High unemployment rates in Eastern Germany (15-20 \%) and Western Germany (6-12 \%) (Federal Bureau of Statistics, 2017b).

7 The main regions of origin currently are war stricken countries like Syria, Afghanistan and Iraq, but also eastern EU states and non-EU countries from Balkan (Federal Bureau of Statistics, 2017b). In 2014, 2015 and 2016 overall 1.6 million refugees more immigrated from Syria, Afghanistan and Iraq to Germany than between 1994 and 2013 on average. The civil war in Syria started in 2011.

${ }^{8}$ Except from Luxemburg (46.7\%), only the EU-15-countries Austria (14.6\%), Belgium (11.8\%) and Ireland (11.6\%) had higher shares of foreign population than Germany in 2015 (Eurostat, 2018a).
} 